\title{
AVALIAÇĀO DA QUALIDADE DE GELÉIAS DE MORANGO COMUM E DIETÉTICA DAS VARIEDADES GUARANI E OSO GRANDE
}

\section{KATIA SIVIERI \\ Bióloga}

Orientador: Prof. Dr. João Nunes Nogueira

Dissertação apresentada à Escola Superior de Agricultura "Luiz de Queiroz”, Universidade de São Paulo, para obtenção do título de Mestre em Ciências, Área de Concentração: Ciência e Tecnologia de Alimentos.

\section{PIRACICABA}

Estado de São Paulo - Brasil

Novembro / 1997 
Dados Internacionais de Catalogação na Publicação (CIP)

DIVISÃo DE BIBLIOTECA E DOCUMENTAÇĀO - Campus "Luiz de Queiroz"/USP

\section{Sivieri, Katia}

Avaliação da qualidade de geléias de morango comum e dietética das variedades Guarani e Oso Grande / Katia Sivieri. - - Piracicaba, 1997.

124 p. : il.

Dissertaçāo (mestrado) - - Escola Superior de Agricultura Luiz de Queiroz, 1997. Bibliografia.

1. Alimento dietético 2. Alimento preparado (qualidade) 3. Geléia 4. Morango 5. Tecnologia de alimento I. Título 


\section{AVALIAÇÃO DA QUALIDADE DAS GELÉIAS COMUM E DIETÉTICA DE MORANGO DAS VARIEDADES GUARANI E OSO GRANDE}

Kátia Sivieri

Aprovada em: 16.12.1997

Comissão julgadora:

Prof. Dr. João Nunes Nogueira

ESALQ/USP

Prof. Dr. Keigo Minami ESALQ/USP

Prof. Dra. Solange Kanniatti Brazzaca ESALQ/USP

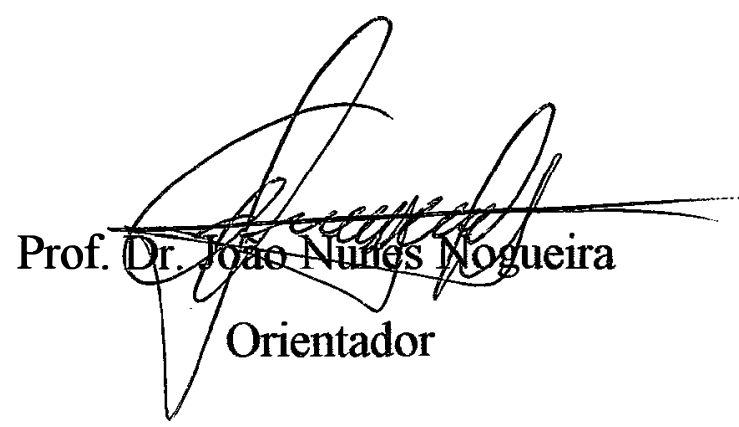


Aos meus pais que sempre me apoiaram em todas decisões da minha vida, Ao Douglas com amor, Aos meus irmãos Christian e Karen com carinho, dedico este trabalho 


\section{AGRADECIMENTOS}

- Ao Prof. Dr. João Nunes Nogueira, pela orientação, apoio e colaboração na elaboração deste trabalho.

- Aos professores do curso de mestrado pelos ensinamentos.

- Aos Srs. Benedito e Oswaldo Marieiro, pela doação da matéria-prima necessária na elaboração deste trabalho.

- À Lucia Cristina da Costa Novaes Godoy, pela amizade, apoio e incentivo.

- À Sra. Ivani Aparecida Marchetto Moreno, técnica do Departarnento de Ciência e Tecnologia Agroindustrial, pelo auxílio prestado na parte prática.

- Aos técnicos Rosemary Leonessa S. Mandro e Sylvino Luiz Torrenzan, pelo auxílio prestado na parte prática.

- À Citropectina S/A, pela doação de pectinas.

- À Bibliotecária Beatriz Helena Giongo, pelo auxílio na revisão e correção das referências bibliográficas deste trabalho.

- À Luciana Turco, pelo auxilio na produção das fotos.

- Aos membros do painel sensorial, pela colaboração.

- Ao Conselho Nacional de Desenvolvimento Cientifico e Tecnológico-CNPq, pelo apoio financeiro a realização deste trabalho.

- À Engenheira Agrônoma Regina Pires do Instituto Agronômico de Campinas, pelo contato com os produtores de morango. 


\section{Sumário}

Página

LISTA DE FIGURAS …................................................. i

LISTA DE TABELAS

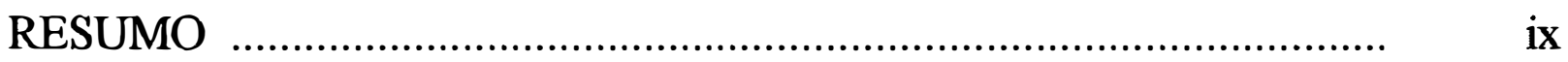

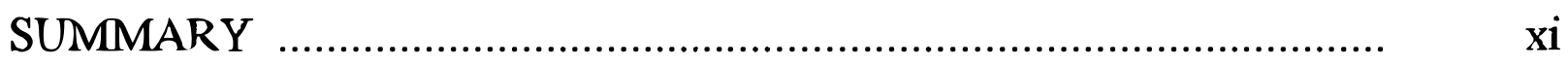

1. INTRODUÇÃO [................................................................... 1

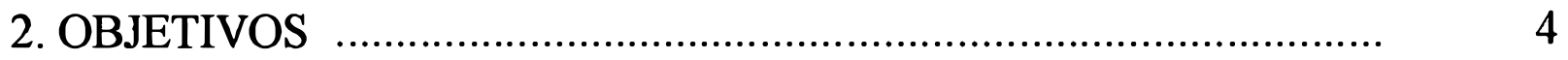

3. REVISÃO DE LITERATURA …............................................. 5

3.1. Considerações gerais ........................................................... 5

3.2. Variedades de morango ........................................................ 7

3.3. Conservação pelo uso de açúcar .................................................

3.4. Geléia comum ................................................................... 10

3.5. Geléia dietética ............................................................... 11

3.5.1. Apertização (esterilização comercial) ........................................ 13

3.6. Substâncias pécticas ............................................................... 13

3.6.1. Pectinas com baixo grau de metoxilação ................................... 16

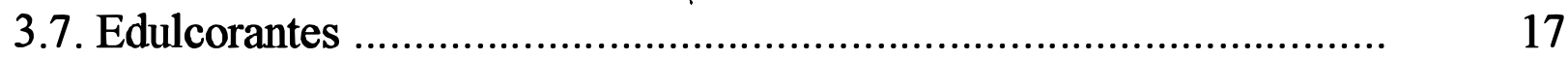


3.7.1. Stevia rebaudiana

3.7.2. Sorbitol

3.8. Fatores que afetam a qualidade das geléias

3.8.1. Cor

3.8.2. Ácido ascórbico

3.8.3. Uso de aditivos

4. MATERIAL E MÉTODOS

4.1. Matéria-prima

4.2. Caracterização da matéria-prima

4.2.1. Análises físicas

4.2.2. Análises químicas

4.3. Processamento

4.3.1. Geléia comum

A. Formulação básica

B. Procedimento

C. Tratamentos para obtenção de geléia comum

4.3.2. Geléia dietética

A. Formulação básica

B. Procedimento

C. Tratamentos para obtenção de geléia dietética 
4.3.3. Acondicionamento

4.3.4. Esterilização e resfriamento

4.3.5. Armazenamento

4.4. Avaliação dos produtos processados

4.4.1. Análises fisicas

4.4.2. Análises químicas

4.4.3. Análises sensoriais.

4.4.4. Análise estatística.

5. RESULTADOS E DISCUSSÃO

5.1. Caracterização da matéria-prima

5.1.1. Análises físicas

5.1.2. Análises químicas

5.2. Caracterização do produto final

5.2.1. Geléia comum

5.2.1.1. Análises físicas

5.2.1.2. Análises químicas

5.2.1.3. Análises sensoriais

5.2.2. Geléia dietética 
5.2.2.3. Análises sensoriais.......................................................... 100

6. CONCLUSÕES …............................................................ 107

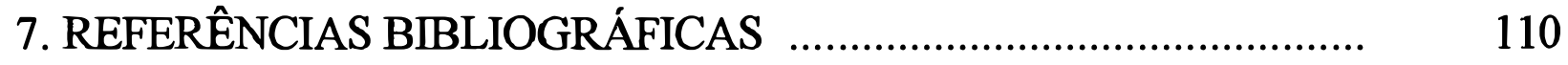


LISTA DE FIGURAS

Página

Figura 1. Fluxograma das operações utilizadas no processamento de geléia comum.

Figura 2. Esquema dos tratamentos aos quais as polpas de morango de cada variedade foram submetidas para obtenção de geléias comuns

Figura 3. Fluxograma das operações utilizadas no processamento de geléia dietética

Figura 4. Esquema dos tratamentos aos quais as polpas de morango de cada variedade foram submetidas para obtenção de geléias dietéticas.

Figura 5. Modelo de ficha utilizado na avaliação sensorial das amostras quanto ao sabor.

Figura 6. Modelo de ficha utilizado na avaliação sensorial das amostras quanto a cor.

Figura 7. Modelo de ficha utilizado na avaliação sensorial das amostras quanto a textura.

Figura 8. Variação dos teores de ácido ascórbico $(\mathrm{mg} / 100 \mathrm{~g}$ amostra) das geléias comuns de acordo com os períodos de armazenamento -Variedade Guarani

Figura 9. Variação dos teores de ácido ascórbico $(\mathrm{mg} / 100 \mathrm{~g}$ amostra) das geléias comuns de acordo com os períodos de armazenamento - Variedade Oso Grande 
Figura 10. Comparação entre as geléias comuns de morango das duas variedades com relação ao teor de ácido ascórbico (mg/ 100g amostra) durante armazenamento.

Figura 11. Comparação entre as geléias comuns de morango das duas variedades com relação ao teor de acidez total titulável ( $\mathrm{g} / 100 \mathrm{~g}$ amostra) durante armazenamento...................

Figura 12. Variação dos teores de acidez total titulável $(\mathrm{g} / 100 \mathrm{~g}$ amostra) das geléias comuns de acordo com os períodos de armazenamento -Variedade Guarani.

Figura 13. Variação dos teores de acidez total titulável $(\mathrm{g} / 100 \mathrm{~g}$ amostra) das geléias comuns de acordo com os períodos de armazenamento - Variedade Oso Grande.

Figura 14. Comparação entre as geléias comuns de morango das duas variedades em relação ao $\mathrm{pH}$ durante 70 armazenamento.

Figura 15. Variação dos valores de $\mathrm{pH}$ das geléias comuns de acordo com os períodos de armazenamento- Variedade Guarani.

Figura 16. Variação dos valores de $\mathrm{pH}$ das geléias comuns de acordo com os períodos de armazenamento- Variedade Oso Grande.

Figura 17. Comparação entre as geléias comuns de morango das duas variedades com relação ao teor de sólidos solúveis (Brix) durante armazenamento.

Figura 18. Variação dos teores de sólidos solúveis (Brix) das geléias comuns de acordo com os períodos de armazenamento Variedade Guarani. 
Figura 19. Variação dos teores de sólidos solúveis (Brix) das geléias comuns de acordo com os periodos de armazenamento Variedade Oso Grande

Figura 20. Valores médios obtidos na avaliação sensorial das geléias comuns quanto ao sabor durante armazenamentoVariedade Guarani.

Figura 21. Valores médios obtidos na avaliação sensorial das geléias comuns quanto ao sabor durante armazenamentoVariedade Oso Grande.

Figura 22. Valores médios obtidos na avaliação sensorial das geléias comuns quanto a cor durante armazenamentoVariedade Guarani

Figura 23. Valores médios obtidos na avaliação sensorial das geléias comuns quanto a cor durante armazenamentoVariedade Oso Grande.

Figura 24. Cortes transversais das variedades Guarani e Oso Grande.

Figura 25. Cortes longitudinais das variedades Guarani e Oso Grande.

Figura 26. Valores médios obtidos na avaliação sensorial das geléias comuns quanto a textura durante armazenamentoVariedade Guarani.

Figura 27. Valores médios obtidos na avaliação sensorial das geléias comuns quanto a textura durante armazenamentoVariedade Oso Grande.

Figura 28. Variação dos teores de ácido ascórbico (mg/ $100 \mathrm{~g}$ amostra) das geléias dietéticas de acordo com os períodos de 
Figura 29. Variação dos teores de ácido ascórbico (mg/ $100 \mathrm{~g}$ amostra) das geléias dietéticas de acordo com os períodos de armazenamento - Variedade Oso Grande.

Figura 30. Comparação entre as geléias dietéticas de morango das duas variedades com relação ao teor de ácido ascórbico (mg/ $100 \mathrm{~g}$ amostra) durante armazenamento.

Figura 31. Variação dos teores de acidez total tituláve $(\mathrm{g} / 100 \mathrm{~g}$ amostra) das geléias dietéticas de acordo com os períodos de arnazenamento - Variedade Guarani.

Figura 32. Variação dos teores de acidez total titulável (g/100g amostra) das geléias dietéticas de acordo com os períodos de armazenamento - Variedade Oso Grande

Figura 33. Comparação entre as geléias dietéticas de morango das duas variedades com relação ao teor de acidez total titulável (g/100g amostra) durante armazenamento.

Figura 34. Variação dos valores de $\mathrm{pH}$ das geléias dietéticas de acordo com os períodos de armazenamento- Variedade Guarani

Figura 35. Variação dos valores de $\mathrm{pH}$ das geléias dietéticas de acordo com os períodos de armazenamento- Variedade Oso Grande.

Figura 36. Comparação entre as geléias dietéticas de morango das duas variedades com relação ao $\mathrm{pH}$ durante armazenamento

Figura 37. Variação dos teores de sólidos solúveis (Brix) das geléias dietéticas de acordo com os períodos de armazenamento - Variedade Guarani. 
Figura 38. Variação dos teores de sólidos solúveis (Brix) das geléias dietéticas de acordo com os períodos de armazenamento -Variedade Oso Grande

Figura 39. Comparação entre as geléias dietéticas de morango das duas variedades com relação ao teor de sólidos solúveis (Brix) durante armazenamento.

Figura 40. Valores médios obtidos na avaliação sensorial das geléias dietéticas quanto ao sabor durante armazenamentoVariedade Guarani

Figura 41. Valores médios obtidos na avaliação sensorial das geléias dietéticas quanto ao sabor durante armazenamentoVariedade Oso Grande.

Figura 42. Valores médios obtidos na avaliação sensorial das geléias dietéticas quanto a cor durante armazenamentoVariedade Guarani.

Figura 43. Valores médios obtidos na avaliação sensorial das geléias dietéticas quanto a cor durante armazenamentoVariedade Oso Grande.......................................................... 
LISTA DE TABELAS

Página

Tabela 1. Características físicas das variedades de morango "in natura"

Tabela 2. Características químicas das variedades de morango "in natura"

Tabela 3. Peso bruto (g) das geléias comuns de morango das duas variedades durante armazenamento

Tabela 4. Peso líquido (g) das geléias comuns de morango das duas variedades durante armazenamento

Tabela 5. Vácuo (pol.Hg) das geléias comuns de morango das duas variedades durante armazenamento

Tabela 6. Teores de ácido ascórbico (mg/100g amostra) das geléias comuns de morango das duas variedades durante armazenamento

Tabela 7. Teores de acidez total titulável (g/ 100g amostra) das geléias comuns de morango das duas variedades durante armazenamento.

Tabela 8. Valores de $\mathrm{pH}$ das geléias comuns de morango das duas variedades durante armazenamento.

Tabela 9. Teores de sólidos solúveis (Brix) das geléias comuns de morango das duas variedades durante armazenamento. 
Tabela 10. Avaliação sensorial do sabor das geléias comuns de morango das duas variedades durante armazenamento.

Tabela 11. Comparação entre as geléias comuns de morango das duas variedades com relação ao sabor durante armazenamento......

Tabela 12. Avaliação sensorial da cor das geléias comuns de morango das duas variedades durante armazenamento

Tabela 13. Comparação entre as geléias comuns de morango das duas variedades com relação a cor durante armazenamento.

Tabela 14. Avaliação sensorial da textura das geléias comuns de morango das duas variedades durante armazenamento

Tabela 15. Comparação entre as geléias comuns de morango das duas variedades com relação a textura durante armazenamento......

Tabela 16. Peso bruto (g) das geléias dietéticas de morango das duas variedades durante armazenamento.........................................

Tabela 17. Peso líquido (g) das geléias dietéticas de morango das duas variedades durante armazenamento

Tabela 18. Vácuo (pol.Hg) das geléias dietéticas de morango das duas variedades durante armazenamento.

Tabela 19. Teores de ácido ascórbico (mg/ $100 \mathrm{~g}$ amostra) das geléias dietéticas de morango das duas variedades durante armazenamento

Tabela 20. Teores de acidez total titulável (g/100g amostra) das geléias dietéticas de morango das duas variedades durante armazenamento

Tabela 21. Valores de $\mathrm{pH}$ das geléias dietéticas de morango das duas variedades durante armazenamento 
Tabela 22. Teores de sólidos solúveis (Brix) das geléias dietéticas de morango das duas variedades durante armazenamento...............

Tabela 23. Avaliação sensorial do sabor das geléias dietéticas de morango das duas variedades durante armazenamento

Tabela 24. Comparação entre as geléias dietéticas de morango das duas variedades com relação ao sabor durante armazenamento......

Tabela 25. Avaliação sensorial da cor das geléias dietéticas de morango das duas variedades durante armazenamento....................

Tabela 26. Comparação entre as geléias dietéticas de morango das duas variedades com relação a cor durante armazenamento............

Tabela 27. Avaliação sensorial da textura das geléias dietéticas de morango das duas variedades durante armazenamento.....................

Tabela 28. Comparação entre as geléias dietéticas de morango das duas variedades com relação a textura durante armazenamento...... 


\section{AVALIAÇÃO DA QUALIDADE DE GELÉIAS DE MORANGO COMUM E DIETÉTICA DAS VARIEDADES GUARANI E OSO GRANDE}

Candidata: Katia Sivieri

Orientador: Prof. Dr. João Nunes Nogueira

\section{RESUMO}

Foram avaliadas as características físicas, químicas e sensorias de geléias de morango comum e dietética elaboradas com as variedades Guarani e Oso Grande com diversos tratamentos, visando a adequabilidade destas para a obtenção de geléias.

A qualidade da matéria-prima e dos produtos processados foi avaliada submetendo-se as amostras às análises físicas de textura, suculência, porcentagem de rendimento (somente para a matéria-prima), peso bruto, peso líquido e vácuo (somente para o produto processado); análises químicas de ácido ascórbico, acidez total titulavel, $\mathrm{pH}$, sólidos solúveis (Brix) e avaliação sensorial de sabor, cor e textura. 
A susceptibilidade das antocianinas à degradação foi observada no tratamento térmico e durante a estocagem. A retenção deste pigmento é um fator decisivo na aceitabilidade das geléias comuns e dietéticas. A adição de cloreto de estanho contribuiu para a manutenção da cor. Os tratamentos que utilizaram ácido ascórbico prejudicaram muito a cor das geléias.

Os resultados mostraram que a variedade Oso Grande foi a que apresentou melhores resultados para elaboração de geléias comuns (exceto para cor). A variedade Guarani foi a que apresentou melhores resultados para elaboração de geléias dietéticas, sendo superior a variedade Oso Grande quanto ao sabor e cor, principais atributos de qualidade das geléias dietéticas. 


\title{
QUALITY EVALUATION OF COMMON AND LOW SUGAR STRAWBERRY JELLIES MADE FROM GUARANI AND OSO GRANDE VARIETIES
}

\author{
Author: Katia Sivieri \\ Adviser: Prof. Dr. João Nunes Nogueira
}

\section{SUMMARY}

The physical, chemical and sensorial characterists of jellies from two strawberry varieties (Guarani and Oso Grande) were determined in order to evaluate their feasibility for common and low sugar jelly processing.

The quality of both raw material and final product was evaluted regarding to physical determinations of texture, succulency, yield percentage (only the raw material), gross weight, net weight, vacuum (only processed product); chemical determinations of ascorbic acid, titratable acidity, $\mathrm{pH}$, soluble solids and organoleptic evaluation for flavor, color and texture.

The anthocyanins susceptibity to degradation was observed during thermal processing and storage. The retention of these pigments is a decisive factor the general acceptance of common and low sugar jellies. 
The addition of stannous choride contributed towards the maintenance of color. Treatments that used ascorbic acid imparied the color of the jellies.

Results showed the Oso Grande as the most suitable variety for common jelly processing (except for color). The Guarani was indicated for low sugar jelly processing, being superior to the Oso Grande in flavor and color, the most important attributes for this kind of product. 


\section{Introdução}

O morango é dentre os frutos pequenos, uma das culturas mais importantes (Dana, 1980). O morangueiro é cultivado em quase todo mundo, sendo que em 1990 os principais produtores foram os Estados Unidos, Polônia, Espanha, Japão e Itália, com respectivamente 538.600, 268.898, 226.800, 220.000 e 201.200 toneladas, segundo dados da FAO (1990). No Brasil em 1993 foram cultivados 613 hectares de morango totalizando uma produção de 26.385 toneladas; em 1994 a produção foi de 26.747 toneladas, passando em 1995 a 27.508 toneladas e atingindo um total em 1996 de 27.040 toneladas (Instituto de Economia Agrícola, 1997).

No Brasil, destacam-se como principais produtores os estados de Minas Gerais e São Paulo, onde a produção se destina em grande parte para o consumo " in natura", enquanto no Rio Grande do Sul, predominam cultivares para a indústria (Ribeiro et al., 1981 ;Groppo \& Tessarioli Neto, 1991). No estado de São Paulo é onde a produção de morango conta com níveis tecnológicos mais altos, e conseqüentemente, com os maiores índices nacionais de produtividade. Parte deste sucesso se deve às pesquisas realizadas pelo Instituto Agronômico de Campinas (IAC) na seleção e adaptação de novas variedades de morango ( Richards, 1996). 
A produção nacional de morango é quase toda voltada para o mercado interno. Nos últimos anos, tem havido exportação em pequena escala da fruta "in natura" ou industrializada para países como a Argentina e o Chile. Segundo alguns analistas, o desenvolvimento da cultura comercial de morango no Brasil pode permitir a exportação, a médio prazo, do morango industrializado para os mercados do Japão e dos Estados Unidos (Padovani, 1991). As poucas industrias que processam o fruto, para atender ao mercado interno o fazem na forma de polpa congelada, que posteriormente é utilizada como matéria-prima na elaboração de geléias, sorvetes, bombons e iogurtes (Berbari, 1992).

No Brasil, a produção de frutas atinge volume expressivo. No entanto, ocorre muitas vezes a perda de parte considerável da safra por falta de comercialização. Diante deste grave problema, uma alternativa pode ser a instalação de agroindustrias gerando produtos como polpa, sucos, néctares, frutas desidratadas, geléias e compotas (Teixeira,1993). As geléias podem ser consideradas como o segundo produto em importância comercial para a industria de conservas de frutas brasileiras. Em outros países, principalmente da Europa, como é o caso da Inglaterra e Alemanha, este produto assume um papel de grande destaque no mercado (Soler, 1991).

Os produtos dietéticos a cada dia estão ganhando mais espaço no mercado. Para os empresários, o mercado dietético foge a qualquer modismo e vem para ficar permanentemente, pois a questão da saúde é uma necessidade básica (A Era diet, 1991). A preocupação em aperfeiçoar os 
produtos dietéticos e introduzir novos sabores é uma conseqüência da competitividade que forçou a indústria brasileira a desenvolver produtos com o mesmo nível de qualidade dos importados (Rodrigues, 1995).

Para satisfazer as exigências dos consumidores atuais e competir no mercado externo, o Brasil necessita de pesquisas em desenvolvimento e melhoramento de produtos alimentícios. Utilizando variedades de morango selecionadas e desenvolvendo formulações adequadas para a obtenção de geleías comum e dietética, tornar-se-á possível oferecer tanto ao mercado interno como ao externo um produto de qualidade, beneficiando diretamente as indústrias, produtores e consumidores. 


\section{Objetivos}

Este trabalho foi desenvolvido tendo como objetivo avaliar a qualidade de geléias de morango nas formas comum e dietética das variedades Guarani e Oso Grande, submetidas a diferentes tratamentos, visando suprir tanto o mercado interno como externo com produtos de alta qualidade. 


\section{Revisão de Literatura}

\subsection{Considerações gerais}

A qualidade do morango é um fator de extrema importância para a sua aceitação no mercado. Vários são os fatores que afetam a qualidade do morango como cultivar, clima, nutrição da planta, sistemas de cultivo, técnicas de colheita, doenças e pragas, maturidade, transporte e armazenamento e métodos de processamento (Morris \& Sistrunk, 1991).

A sazonalidade da produção é um dos principais problemas da cultura do morangueiro. O clima exerce um papel preponderante no desempenho dos cultivares, bem como na ocorrência de pragas e doenças (Tessarioli Neto,1993). Segundo Figueira (1982), a temperatura efeta decisivamente a qualidade do morango, sendo o principal fator limitante à expansão da cultura no Centro Sul do País. O comprimento do dia também afeta a cultura, sendo que os dias curtos estimulam, sensivelmente a frutificação, enquanto os dias mais longos, favorecem a fase vegetativa, estimulando a emissão de estolhos. É a interação entre o fotoperíodo e a temperatura que determina a adaptação de um cultivar em determinada localidade (Nelson et al., 1976). 
O sucesso alcançado pela cultura do morango na Califómia, é devido ao trabalho de melhoramento genético, com obtenção de novos cultivares, desenvolvimento de novas técnicas de cultivo e a manipulação fisiológica destes novos materiais (Voth \& Bringhurst, 1990). A matéria-prima é característica básica para a qualidade do produto processado. A seleção da variedade, a região de cultivo, as práticas culturais e o estágio de maturação na colheita, assim como o manuseio do produto colhido antes do processamento, são fatores importantes a serem considerados (Paschoalino, 1979).

A seleção de variedades apropriadas para o processamento é um importante passo no sentido de se obter um produto de boa qualidade. Uma determinada variedade pode possuir características muito boas em relação à produção, resistência à doenças e época de maturação adequada, porém pode não ser recomendada devido à sua baixa qualidade para processamento. Por outro lado, algumas variedades podem ser apropriadas para serem processadas por apertização, porém podem não sê-lo para congelação ou desidratação (Fonseca \& Nogueira, 1984).

A primeira meta a ser cumprida, na longa série de providências para oferecer à industria de alimentos matéria-prima de melhor padrão, é a execução de um plano destinado a produzi-la sob moldes técnicos, visando melhorar a qualidade, quantidade e particularidades específicas, para a sua aplicação em determinados produtos (Evangelista,1992). A procura e aceitação de qualquer produto é função de sua qualidade. Daí a importância 
de se empregar no processamento, além de uma matéria-prima de boa qualidade, técnicas que permitam a máxima preservação das características que o produto possuía quando no estado fresco (Fonseca \& Nogueira, 1984).

\subsection{Variedades de morango}

O morangueiro pertence a família das rosáceas, gênero Fragaria. Dezesseis espécies de diplóides e octaplóides que vai de 14 a 56 cromossomos são descritos por Hancock (1990). Cultivares modernos de morango tem como principais progenitores duas espécies de octaplóides: Fragaria virginiana DUCH. e Fragaria chiloensis L. DUCH. (Camargo,1960; Hancock, 1990)

O morangueiro só passou a ter importância comercial em meados do século passado, uma vez que até então suas variedades todas silvestres, produziam frutos pequenos e em quantidades muito limitadas. Todas as variedades cultivadas atualmente são produtos de um longo trabalho de seleção e hibridização. Estas variedades são muito distintas entre si no que diz respeito à sua importância, resistência a moléstias, condições ecológicas, forma, cor, firmeza, tamanho e sabor dos frutos (Padovani, 1991).

A investigação da qualidade das variedades de morangos para 0 processamento industrial é um ponto de grande importância. A adequabilidade da variedade é influenciada por propriedades químicas e 
fisicas da fruta, pelo comportamento nas varias etapas do processo industrial e pelas características agronômicas (Skrede, 1982).

Para a industrialização, há que se distinguir as exigências dos vários métodos de processamento. Visando a manutenção da forma dos frutos de interesse para o congelamento e confecção de compotas, há necessidade de textura rígida. Os clones Alemanha, Tioga, Guarani e IAC-4936 apresentaram boas características, tendo potencialidade para serem cultivados. A variedade Guarani apresentou coloração vermelho interna mais intensa, o que seria de interesse na conservação da cor por vários meses em produtos processados, e, também, na possibilidade de substituir o uso de corantes. A variedade Guarani foi caracterizada com análises físicas e químicas resultando valores de Brix 5,8; $\mathrm{pH} 3,45$; acidez 1,08\% ( $\%$ de ácido cítrico/100g de morango) e textura 81,67 ( $\mathrm{lbf} / 50 \mathrm{~g}$ de morango) ( Passos, 1982).

Diversas variedades de morangos são utilizadas no processamento de geléias. A produção em larga escala usando processos automatizados, requer caracterização da matéria-prima antes do processamento (Skrede, 1980). A variedade Oso Grande é oriunda da Califórnia e lançada no Brasil em 1994, pelo Instituto Agronômico de Campinas. Esta variedade tem como características principais: aroma forte e agradável, textura firme, resistência à pragas, $\mathrm{pH}$ em torno de 3,8 e Brix ao redor de 8,6. 
A variedade Guarani (IAC-5074) é apresentada por Passos \& Tessarioli Neto (1979) como um clone promissor com as seguintes características: é precoce com boa produtividade, competindo com os cultivares Campinas e Monte Alegre, boa estabilidade de produção, intensa coloração externa e interna, bom tamanho e boa fimeza. O clone Guarani foi obtido do cruzamento realizado em 1974 entre os clones Campinas x Monte Alegre e o clone Alemanha.

\subsection{Conservação pelo uso de açúcar}

O açúcar, especialmente quando aliado ao aquecimento, é um bom agente de conservação dos alimentos. A presença do açúcar irá aumentar a pressão osmótica do meio, criando condições desfavoráveis para o crescimento e reprodução da maioria das espécies de bactérias, fungos e leveduras (Gava, 1984). Os produtos adicionados de açúcar adquirem condições que permitem prolongar sua vida de prateleira (Evangelista, 1992).

Os microrganismos osmofilicos conseguem sobreviver em condições de baixo teor de umidade e, por isso, todo alimento conservado pelo uso de açúcar deve receber um tratamento complementar para sua conservação (Gava, 1984). As geléias, doces em massa, frutas cristalizadas e compotas são exemplos de produtos conservados pela presença de açúcar. 


\subsection{Geléia Comum}

Segundo as Normas Técnicas relativas a alimentos e bebidas, anexas ao Decreto número 12486 de 20 de outubro de 1978, estabelece-se que a geléia de fruta é o produto obtido pela cocção de frutas inteiras ou em pedaços, polpa ou sucos de frutas, com açúcar ou água, e concentrado até a consistência gelatinosa (Jackix, 1982; Código,1991).

De acordo com Leme Jr. (1976), a geléia de fruta pode ser definida como um produto composto por suco de frutas, açúcar, ácido e pectina (presentes naturalmente nas frutas ou adicionados). Deve possuir aparência transparente, ou quase. A consistência deve ser tal que, tirada a conserva da embalagem que a contém, esta deve manter sua forma, sofrendo apenas uma diminuição ou achatamento de pirâmide, devendo conservar seus ângulos inalterados.

São considerados elementos básicos para a elaboração de uma geléia: fruta, pectina, ácido, açúcar e água. Uma combinação adequada deles, tanto na quantidade como na ordem de colocação durante o processamento, irá definir a qualidade da geléia (Soler, 1991).

A textura característica das geléias resulta da formação de uma rede de moléculas poliméricas, obtida pela presença da pectina. Para entender as 
propriedades físicas, químicas e organolépticas dos géis, é necessário saber como se forma esta rede de polímeros e conhecer os fatores que afetam a sua estabilidade (Oakenfull \& Scott, 1985).

\subsection{Geléia dietética}

Entende-se por alimentos dietéticos, todos alimentos especialmente formulados e/ou modificados, destinados a pessoas sadias ou não, e que são utilizados em dietas diferenciadas ou opcionais (Rodrigues, 1995).

Como forma de atender às recomendações dos órgãos de saúde a nível internacional, os quais advertem sobre a necessidade de haver redução de açúcares, surgiu a preocupação de como harmonizar o prazer da doçura com a manutenção da saúde. A solução encontrada foi a utilização de adoçantes e edulcorantes para substituir a sacarose. As razões para esta substituição incluem não só a expansão da disponibilidade de alimentos e bebidas com restrição calórica ou carboidratos para o controle do peso, diabetes e prevenção das cáries, mas também para contornar problemas de processamento relacionados com uso da sacarose (Campos \& Cândido, 1995).

Geléia dietética é um produto obtido pela cocção de frutas inteiras ou pedaços, polpa ou suco de frutas e água, sem utilização de sacarose, 
utilizando-se em sua substituição uma outra substância capaz de conferir gosto doce ao produto. Para se obter a consistência gelatinosa, característica do produto, este deve ser adicionado de pectina de baixo grau de metoxilação e concentrado térmicamente (Soler,1991).

O emprego de substitutos de açúcar na elaboração de geléias acarreta alterações na formação do gel de pectina e nas condições para obtenção do produto sendo que alguns pontos básicos devem ser levados em conta: - os valores de sólidos solúveis determinados pelo Brix não correspondem aos sólidos solúveis verdadeiros, uma vez que o método foi padronizado para a determinação da sacarose; - as propriedades estabelecidas do gel de pectina são alterados; - a conservação do produto requer a adição de conservadores ou armazenamento sob refrigeração; - a ausência da caramelização e reação de Maillard, e a reduzida fixação de aroma exigem, em certas ocasiões, a utilização de corantes e flavorizantes (Campos \& Cândido, 1995).

A industria de processamento de fruta é a principal consumidora de pectina, sendo a geléia o produto mais importante. As geléias destinadas a restrição calórica ou para diabéticos são formuladas pelo uso de pectinas de baixo teor de metoxilação, que formam gel na presença de ions bivalentes, normalmente o cálcio (Cristensen, 1986). Segundo Campos \& Cândido (1995), geléias de morango dietéticas que continham estévia e sorbitol em sua formulação apresentaram as seguintes características físico-químicas e 
reológicas: pH 3,20; sólidos solúveis (\%) 24,5; fluidez do gel (mm) 50 e força do gel (mm) 120.

\subsubsection{Apertização ( esterilização comercial)}

Dos processos de conservação pelo uso do calor, o tratamento térmico em recipientes hermeticamente fechados constitui, no momento, o de maior importância industrial, mundialmente empregado, não só na industria, como na produção doméstica (Gava, 1984).

O processo Appert, pode ser considerado e definido como o simples aquecimento do produto, anteriormente preparado, em recipientes fechados, na ausência relativa de ar, até uma certa temperatura e num tempo suficiente para a destruição dos microrganismos deterioradores, porém sem alterar de modo sensível o alimento (Gava, 1984).

As geléias dietéticas são produtos isentos de açúcares, portanto necessitam da aplicação de um processo de conservação. Este processo pode ser a apertização, ou seja um tratamento térmico, em recipientes hermeticamente fechados, seguidos de resfriamento até a temperatura ambiente.

\subsection{Substâncias pécticas}


A pectina é um hidrocolóide natural, presente em todas as frutas como componente das paredes celulares. Enquanto na forma de protopectina, é insolúvel em água, devido ao alto peso molecular e interação com outros componentes da parede celular. À medida que ocorre o processo de maturação das frutas, a protopectina vai se transformando em pectina solúvel, o que pode ser facilmente observado pelo amolecimento das mesmas (Leme Jr., 1968). Tradicionalmente a pectina é usada na indústria alimentícia como agente geleificante, espessante ou estabilizante.

A pectina é comercialmente extraída da casca de frutas cítricas e de maçãs, por hidrólise ácida à quente, seguida por um processo de precipitação alcoólica ou alcalina. A substância resultante (pectina em estado bruto) é submetida então à purificação, secagem, moagem e homogeneização. O controle das fases do processo permite a obtenção da pectina em duas formas: de alto metoxil (DM acima de 50\%) e de baixo metoxil (DM abaixo de $50 \%$ ). A pectina de baixo metoxil é produzida a partir da pectina de alto metoxil, submetida a um tratamento ácido ou alcalino, que promove a desesterificação parcial de suas cadeias e a substituição de alguns grupos metoxílicos por grupos amina. Todas as fases da fabricação da pectina obedecem a parâmetros constantes, que levam em conta a matéria prima utilizada e o produto final desejado (Catálogo CITROPECTINA, 1996).

As pectinas são substâncias existentes nas plantas, constituídas de ésteres metílicos de ácidos poligalacturônicos, capazes de geleificar açúcares 
em meios com alta concentração destes e com acidez adequada (Leme Jr., 1976). O gel é um sistema onde a pectina existe no estado entre a solução e a precipitação. A adição de qualquer substância, que reduza a solubilidade da pectina vai favorecer a formação do gel. $\mathrm{O}$ ácido poligalacturônico das moléculas de pectina se encontra parcialmente metoxilado. Este grau de esterificação ou metoxilação varia com o método de extração, com a localização no tecido celular e com o estádio de maturação da fruta. Segundo a porcentagem de grupos carboxílicos esterificados, as pectinas dividem-se em pectinas de alto teor de metoxilação (de 50 a $80 \%$ ) e de baixo teor de metoxilação (< 50\%) (Fiszman, 1989).

As pectinas com alto teor de metoxilação, para geleificarem, exigem um baixo valor de $\mathrm{pH}$ ( 3.0 a 3.5) para diminuir o grau de repulsão entre os grupos carboxílicos ionizados por neutralização de suas cargas. Por outro lado, há necessidade da presença de um polialcool como agente desidratante (açúcares, glicóis ou glicerol), que permita a aproximação das moléculas, para formação do gel (May \& Stansby, 1986). Por vários anos se pensou que existia uma intercalação açúcar-pectina-água por pontes de $\mathrm{H}^{+}$. Hoje se sabe que este tipo de união é demasiado débil para sustentar um gel (Fiszman, 1989).

As condições mencionadas: acidez e presença de açúcar para formação de gel, fazem com que as pectinas de alto teor de metoxilação sejam utilizadas comercialmente e de forma generalizada em todo o mundo 
para elaboração de geléias de fruta. $O$ grau de esterificação controla a temperatura de geleificação. Desta forma, uma pectina com alto grau de metoxilação (ou esterificação) entre 70 e $80 \%$ é denominada de "rapid set", enquanto que uma pectina de grau entre 55 e $65 \%$ se denomina "slow set"(Soler, 1991).

Segundo Carbonell et al. (1991), que estudaram a influência do tipo de fruta na força do gel, concluíram que em geléias de morango um ótimo valor de sólidos solúveis (Brix) depende da quantidade de pectina adicionada e não da pectina presente nos morangos. Um ótimo valor de Brix em geléias de morango varia entre 61 a 67,5 dependendo do tipo e quantidade de pectina adicionada.

\subsubsection{Pectinas com baixo grau de metoxilação}

As pectinas com baixo grau de metoxilação ou esterificação são obtidas à partir da desesterificação das pectinas com alto teor de metoxilação, utilizando-se ácido, enzimas e álcalis (Siguemoto,1993). A geleificação das pectinas de baixo grau de metoxilação segue o seguinte mecanismo: as moléculas adotam um conformação de fitas dobradas que se dispõem de forma paralela e são capazes de agregar entre elas íons $\mathrm{Ca}^{++}$que estabilizam o sistema (Mitchell \& Blanshard, 1976). 
A concentração de cálcio necessária para geleificação depende do método de desesterificação, do grau da mesma e da presença de grupos amidados (Pedersen, 1980). Quando a desesterificação da pectina de baixo teor de metoxilação se realiza em meio ácido, a ruptura dos grupos metil se processa ao acaso e o sistema final requer menos cálcio para geleificar do que quando se aplicam métodos enzimáticos que levam a formação de blocos desmetoxilados. A dependência do grau de desesterificação se manifesta quando a geleificação é favorecida por uma determinada concentração de cálcio (Fiszman, 1989).

Desta forma, as pectinas de baixos teores de metoxilação não necessitam de açúcar para formarem gel, o que faz com que estes compostos sejam largamente utilizados na industrialização de alimentos dietéticos, que não podem incluir a sacarose em suas formulações.

\subsection{Edulcorantes}

Edulcorantes são aditivos para alimentos, definidos como substâncias orgânicas artificiais não glicídicas, capazes de conferir gosto doce aos alimentos (Muradian \& Penteado, 1990). Segundo Angelucci (1990), edulcorantes são substâncias com gosto extremamente doce, não necessariamente açúcares ou polióis, embora possam contê-los como parte integrante de suas moléculas, não necessariamente energética, com poder adoçante muito superior ao da sacarose. 
O emprego de edulcorantes na industria de alimentos encontra justificativa nos produtos destinados a consumidores que necessitam de restrição calórica em suas dietas, bem como para aqueles portadores de diabetes (Muradian \& Penteado, 1990).

Os produtos encontrados atualmente no mercado apresentam grau de doçura adequado, porém não possuem as mesmas características da sacarose quanto à estabilidade térmica, brilho e corpo. A maioria das formulações de produtos dietéticos, é obtida de combinações de vários produtos na tentativa de imitar uma formulação com características semelhantes àquela obtida pela sacarose (Soler, 1991).

\subsubsection{Stevia rebaudiana}

Esteviosídeo é um adoçante natural encontrado nas folhas, caule, inflorescência da Stevia rebaudiana, uma planta perene da família das Compositae (Sakaguchi \& Kan, 1982). Esta planta é originária do Paraguai, onde cresce espontaneamente. No Brasil, a planta é cultivada principalmente nos Estados de São Paulo e Mato Grosso do Sul (Felipe, 1977).

A utilização de Stevia como adoçante na América do Sul estão relatados em documentos dos conquistadores espanhóis da época, 
documentos esses que são mantidos no Arquivo Nacional de Assunção, capital do Paraguai (Sakaguchi \& Kan, 1982).

Dentre as substâncias de gosto doce presentes nas folhas de Stevia rebaudiana, o esteviosídeo A é a principal (Randi \& Felipe, 1980). Esta substância é constituída de aglicona, uma estrutura dieterpenóide (esteviol ou isoesteviol) com 3 moléculas de glicose. Através de análises cromatográficas dos extratos das folhas e do caule de Stevia, observaram-se compostos similares ao esteviosídeo, que são rebaudiosídeos $\mathrm{A}, \mathrm{D}$, e $\mathrm{E}$ e os glicosídeos A e B (Miyoshi, 1977).

Todos os glicosídeos da Stevia, em função das suas estruturas químicas tridimensionais, apresentam potentes glicóforos (agrupamentos intra moleculares), capazes de sensibilizar as papilas gustativas, produzindo uma sensação de gosto muito doce (Alvarez et al., 1989). Entretanto, existe uma grande variação quanto a intensidade e qualidade de doçura destes compostos. Dentre estes, os que alcançam maior importância são o esteviosídeo e o rebaudiosídeo A. A qualidade de doçura dos adoçantes de Stevia em comparação à sacarose, é semelhante, apenas o sabor residual do esteviosídeo tem permanência mais evidente e prolongada do que o da sacarose (Ishima \& Katayama, 1976). O aperfeiçoamento do gosto do steviosideo é objetivo de inúmeros estudos de pesquisa. A aproximação do gosto do esteviosídeo ao gosto da sacarose se faz necessário, pois o nível de 
qualidade da sacarose é superior ao do esteviosídeo (Sakaguchi \& Kan, 1982).

Quando utilizado em processamento de alimentos o esteviosídeo apresenta as seguintes características: a) em condições normais de processamento térmico não ocorre decréscimo no grau de doçura (Abe \& Sonobe, 1977) e nem alteração na cor (Katayama ${ }^{1}$ citado por Sakaguchi \& Kan, 1982); b) embora seja pouco solúvel em água, geralmente não apresenta problemas pois, seu grau de doçura é extremamente alto (Kubota ${ }^{2}$ citado por Sakaguchi, 1982); c) em solução alcalina forte ocorre diminuição do grau de doçura e da solubilidade (Maruzen ${ }^{3}$, citado por Sakaguchi \& Kan, 1982).

Quanto a inocuidade do esteviosídeo, estudos realizados por Pomaret \& Lavielle em Sweeting (1979), revelaram, que não há ação hemolítica e não observaram efeitos tóxicos administrando o esteviosídeo subcutâneamente em camundongos. Ao se administrar oralmente em galos, observou-se que o esteviosídeo é eliminado pelo trato digestivo sem metabolização. Sendo assim, o esteviosídeo não tem valor energético, podendo portanto, ser utilizado como um substituto dos adoçantes sintéticos.

Em relação ao metabolismo, experimentos realizados com ratos demonstraram que o esteviosideo e o rebaudisideo A são degradados a

${ }^{1}$ KATAYAMA, O. Atarashii kanmigen stevioside rui no shurui to shoseistsu. Journal Food Science, v.18, p.31-36, 1978.

${ }^{2}$ KUBOTA, A. Tennentoo o shutai to shi, srevioside o ganyuu suru fukugookannizai. Nippon Kookai Tokkyo Koohoo, v.52, p.145563.

${ }^{3}$ MARUZEN KASEI, S.A. Steviosideo no shokuhin e no ryoo. Catálago, firma Maruzen Kasei, 1978. 
steviol e glicose pela flora intestinal, o qual é absorvido pelo cecum. A glicose absorvida foi metabolizada e excretada no forma de $\mathrm{O}_{2}, \mathrm{CO}_{2}$ e $\mathrm{H}_{2} \mathrm{O}$ (Nabors \& Gelardi, 1986).

Os edulcorantes da Stevia (esteviosídeo e extrato doce) tiveram seu uso autorizado pela Portaria $n^{0} 14$ de 26/01/88 da SNVS do Ministério da Saúde, para aplicação em alimentos, bebidas e medicamentos num limite máximo de $60 \mathrm{mg} / 100 \mathrm{~g}$ ou $100 \mathrm{ml}$ (Alvarez et al., 1989).

\subsubsection{Sorbitol}

O sorbitol é o poliol mais encontrado na natureza (maçã, pêra, pêssego, ameixa) (Almeida, 1996). Ele pertence à categoria dos álcoois poliídricos ou polióis (Muradian \& Penteado, 1990). Os polióis podem ser divididos em duas classes : os polióis aciclicos (aldióis, gliceróis) e os ciclióis (sorbitol, manitol e xiliol). O sorbitol e o manitol são utilizados freqüentemente nas industrias alimentícias e farmacêuticas (Emodi, 1982).

Os polióis são importantes em alguns alimentos pelas suas propriedades como umectante, seqüestrante de certos metais multivalentes, estabilizantes, agente de controle da viscosidade, estabilidade sobre uma larga faixa de $\mathrm{pH}$ e não sofre modificações quando submetidos às 
temperaturas usuais de processamento (Muradian \& Penteado, 1990; Soler, 1991; Nabors \& Gelardi,1986). O sorbitol como edulcorante, embora não substitua totalmente os açúcares apresenta-se como um substituto alternativo em vários tipos de produtos ( Soler, 1991).

Segundo Nabors \& Gelards (1986), o sorbitol é comercialmente produzido pela hidrogenação da dextrose conforme esquema a seguir:
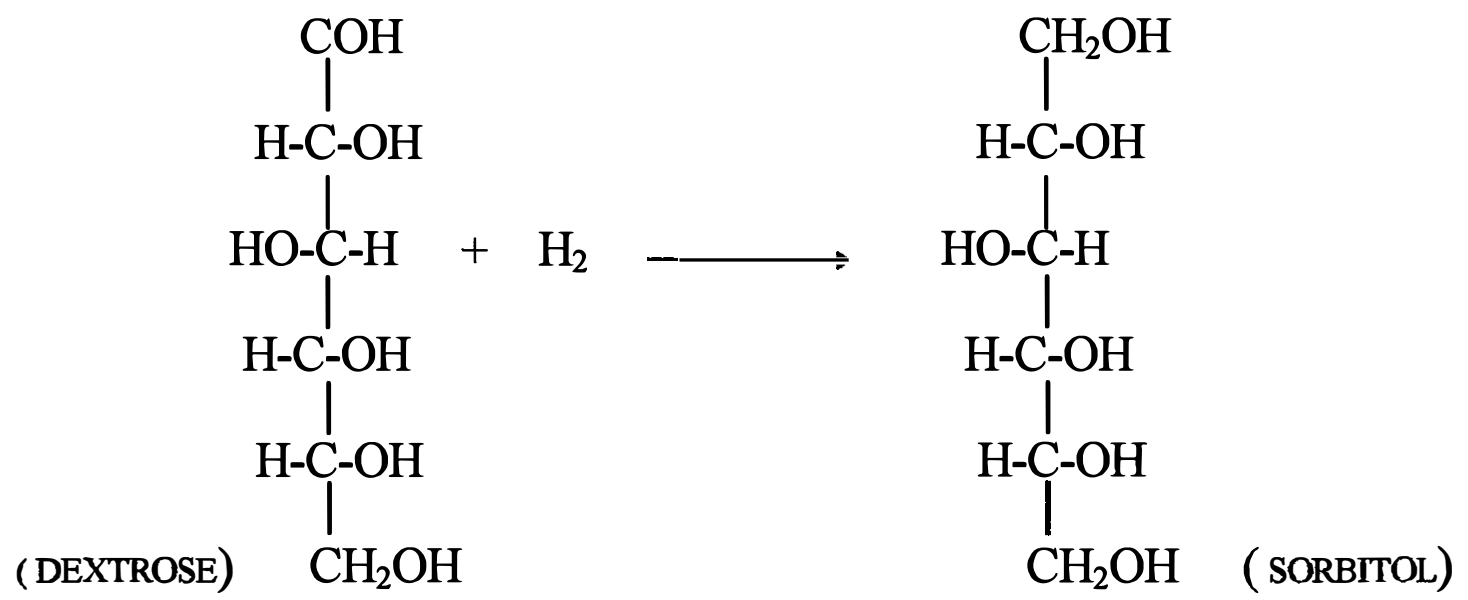

O sorbitol é um nutriente natural que administrado por via oral, é absorvido pelo trato gastrointestinal mais lentamente que a dextrose (Soler, 1991). O metabolismo do sorbitol e do xilitol são similares e ambos são absorvidos pelo intestino por difusão passiva e metabolizados no fígado (Emodi,1982). Segundo, Nabors \& Gelardi (1986), os polióis não absorvidos alcançam o cólon e causam a diarréia osmótica. A tolerância humana de ingestão de sorbitol por dia é de $15-20 \mathrm{~g}$. 
Quando metabolizado, o sorbitol é transformado em frutose no figado pela enzima poliol desidrogenase (Soler, 1991; Emodi, 1982 ; Nabors \& Gelardi, 1986). Assim como a frutose, o metabolismo do sorbitol é inteiramente independente da insulina e, por esta razão, é utilizado como um substituto do açúcar em alimentos destinados à dietas especiais. Seu valor calórico é de aproximadamente quatro calorias por grama, o mesmo dos açúcares (Soler, 1991).

Quando os polióis são consumidos o $\mathrm{pH}$ da saliva fica em torno de 5,0 , mas na presença de dextroses ou sacarose há uma imediata produção de ácido e o $\mathrm{pH}$ da saliva fica em torno de 3,5 a 4,5. Esta acidez é a causa da descalcificação do esmalte dentário (Emodi, 1982). O sorbitol em contraste com a sacarose não provoca cárie dentária por ser resistente às fermentações pela placa bacteriana (Soler, 1991).

\subsection{Fatores que afetam a qualidade das geléias}

\subsubsection{Cor}

A percepção do mundo ao nosso redor é dada pelos nossos sentidos. Destes o impacto visual é o mais importante, não sendo definido apenas pela forma e aspecto dos objetos, mas também pela cor. Dos três principais atributos de qualidade dos alimentos (cor, sabor e textura) a cor torna-se cada 
vez mais importante, à medida que os alimentos são expostos e vendidos (Ferreira, 1991).

O estudo da estabilidade da cor de produtos alimentícios tem grande importância, pois, quando se escolhe, seleciona ou simplesmente se observa um alimento qualquer, o impacto visual causado pela cor geralmente se sobrepõe ao causado pelos outros atributos e isto porque as cores os caracterizam sobremaneira, constituindo-se no primeiro critério aplicado para a sua aceitação ou rejeição. Isso porque se aceita ou não um alimento, em primeiro lugar com os olhos, ou seja, pela cor. Se a cor não for atraente, apesar da aparência (aspecto e forma) e odor, dificilmente o alimento será ingerido ou pelo menos provado (Ferreira, 1991).

As antocianinas estão localizadas na derme das frutas como maçãs, pêras, groselhas e outras. Na maioria das frutas elas se acumulam em vacúolos do tecido da epiderme e sub-epiderme e em outras elas podem ser encontradas tanto na derme como na polpa. A diferença entre as cores das frutas dependem da quantidade e tipo de antocianina presente. As antocianinas são sintetizadas durante $\mathrm{o}$ amadurecimento e geralmente $\mathrm{o}$ conteúdo total das mesmas é considerado como índice de maturação das frutas (Gross, 1987).

A formação de antocianinas depende de vários fatores do meio ambiente tais como, luz, temperatura, água, açúcar exógeno e infecções. $\mathrm{O}$ mais importante efeito é o da luz, que é resultante da ativação de diferentes 
enzimas. Uma série de frutas como morangos e maçãs, apresentam durante a maturação uma correlação direta entre a formação de antocianinas e a atividade da enzima fenilalanina (PAL). Em relação à temperatura as frutas desenvolvem uma melhor coloração em regiões mais frias. Baixas temperaturas ou seja até $6^{\circ} \mathrm{C}$ estimulam à síntese de antocianinas (Gross,1987).

Vários pesquisadores tem enfatizado a importância da cor na qualidade dos morangos. A concentração e o tipo de pigmento são fatores chaves que determinam a intensidade e a qualidade da cor (Morris \& Sistrunk, 1991). A instabilidade da cor em produtos que contém morango como: geléias, purês, e sucos é um grande problema. Reações de Maillard, escurecimento enzimático, degradação do ácido ascórbico e polimerização das antocianinas com outros fenóis podem contribuir para a perda da cor vermelha e aumentar o escurecimento em sucos de morango (Bakker et al., 1992)

A estabilidade da antocianina depende do meio e da concentração do pigmento, $\mathrm{pH}$, presença de copigmentos, ions metálicos, enzimas, ácido ascórbico, açúcares e outros fatores (Mazza \& Miniati, 1990). Produtos contendo antocianinas estão sujeitos a degradação da cor durante o processamento e estocagem; esta degradação é resultante de efeitos combinados de degradação das antocianinas e formação de pigmentos marrons (Abers \& Wrolstad, 1979). Várias espécies de frutas contém 
diferentes tipos de antocianinas, que podem influenciar no grau de degradação da cor (Skrede, 1992).

Segundo Morris \& Sistrunk (1991), a pelargonidina-3-glicosideo (P3G) e a cianidina-3-glucosideo (C3MG) são os pigmentos de maior importância em morangos. A C3MG é mais estável, aumenta com o tempo de estocagem e geralmente está presente em menores quantidades. Alguns genótipos contém porcentagens maiores de C3MG que outros e podem oferecer um meio de criar e selecionar os genótipos com uma maior estabilidade da cor.

A interação do ácido ascórbico com a antocianina e conseqüente degradação mutua é importante, desde que a fruta contenha altas concentrações de ácido ascórbico. Condições que favoreçam a oxidação aeróbia do ácido ascórbico em sucos de morango é a principal causa da perda da cor nestes produtos (Bakker et al., 1992). O ácido ascórbico na concentração de $50 \mathrm{mg} / 100 \mathrm{ml}$ de suco de morango resulta na perda de cor vermelha e desenvolvimento de cor marrom quando estocado à $21-27^{\circ} \mathrm{C}$ (Morris \& Sistrunk,1991).

Segundo Abers \& Wrolstad (1979), estudando as variedades Tioga e Hood observaram que a variedade Tioga apresenta uma rápida deterioração de seus pigmentos e formação de pigmentos marrons durante a estocagem. Análises de composição mostraram que a variedade Tioga contém alta concentração de fenóis reativos ( leucoantocianinas e catequinas). Conclui-se 
que reações destes compostos aumentam a taxa da deterioração da cor em morangos processados.

Vários autores citam que sistemas enzimáticos são capazes de degradar as antocianinas (Markakis, 1982). Segundo Bobbio \& Bobbio (1989), as antocianinas são facilmente descoloridas por reações enzimáticas, uma vez que são hidrolizadas ou oxidadas por antocianases e catecolases, respectivamente, com formação de produtos sem cor.

A polifenoloxidase ( $\mathrm{PPO}$ ) tem sido relacionada com a rápida degradação de antocianina em frutas. Os principais métodos de prevenção da mudança de cor pela PPO são a inativação pelo calor, redução do $\mathrm{pH}$, diminuição da atividade de água, minimização do nível de oxigênio e adição de antioxidantes (Morris \& Sistrunk,1991).

Em relação à temperatura de processamento, vários trabalhos reportam a destruição logaritimica da cor com aumento linear da temperatura. Markakis (1982) mostrou que o processamento do morango a $100^{\circ} \mathrm{C}$ por uma hora resultou na destruição de $50 \%$ da antocianina da fruta. Abers \& Wrolstad (1979), estudaram a relação entre tempo e temperatura de armazenamento e determinaram que $18^{\circ} \mathrm{C}$ é a temperatura crítica ou seja com o aumento desta ocorre a perda da cor vermelha com formação de pigmentos marrons. 
A velocidade de degradação de antocianinas é significativamente influênciada pelas temperaturas de processamento e armazenamento ( Adams \& Ongley, 1973). Estes autores mostraram que a destruição dos pigmentos em conservas de morango foi pequena durante o processo de esterilização, utilizando o sistema UHT, em comparação com as perdas ocorridas durante o resfriamento e armazenamento, o que é atribuído à possibilidade de uma reação de condensação, com o aumento de pigmentos poliméricos em função da temperatura de estocagem ( Markakis 1982).

$\mathrm{O} \mathrm{pH}$ exerce uma profunda influência na cor das antocianinas sendo mais estáveis em soluções ácidas do que em soluções neutras ou alcalinas. $\mathrm{O}$ oxigênio e a temperatura são os agentes mais importantes na deterioração das antocianinas em sucos de morangos, groselhas, cerejas e amoras (Markakis, 1982).

A perda das antocianinas e/ou formação de compostos marrons em produtos processados com morangos durante a estocagem tem sido atribuída a muitos fatores ou combinação de fatores como: $\mathrm{pH}$ e acidez, compostos fenólicos, degradação de açúcares, oxigênio e ácido ascórbico (Spayd \& Morris, 1981).

Os dois mecanismos de oxidação das antocianinas de morangos por peróxido de hidrogênio proposto por Sondheimer \& Kertesz (1948) ajudaram a explicar muitas das mudanças na cor durante o processamento. O peróxido de hidrogênio atua na oxidação do ácido ascórbico para o ácido 
dehidroascórbico. A $20^{\circ} \mathrm{C}$ um aumento de íons ferrosos $\left(\mathrm{Fe}^{2+}\right)$ e de ácido ascórbico aceleram a razão de degradação de antocianinas. Os íons $\mathrm{F}^{2+}$ catalisam a destruição dos pigmentos, mesmo quando o ácido ascórbico não está presente, porém aparentemente, precisa-se de ácido ascórbico para manter a velocidade da reação.

Segundo Spayd \& Morris (1981), a adição de morangos imaturos na elaboração de geléias reduz os níveis de antocianinas, mas não influencia na perda da cor e descoloração durante o armazenamento a 2,25 e $35^{\circ} \mathrm{C}$

\subsection{2. Ácido Ascórbico}

A vitamina C (ácido ascórbico) é uma importante vitamina pertencente às vitaminas hidrosoluveis. Quando há carência desta vitamina no organismo as conseqüências são: hemorragias, deformações e perda de cartilagem, anemia por alterações das células sanguínias, perda de cálcio e perda de dentes (Ramos et al., 1989).

Os tratamentos a que os alimentos são submentidos durante a elaboração e preparação podem causar uma série de modificações em sua composição, que podem afetar tanto as propriedades nutritivas como organolépticas. $\mathrm{O}$ ácido ascórbico pode sofrer importantes perdas durante o processamento. Por ser uma vitamina termolábel e hidrosoluvel, ela é facilmente destruída durante o processamento (Cid et al., 1990). 
A determinação do conteúdo de ácido ascórbico em vegetais processados é muito importante, pois, além do seu papel fundamental na nutrição humana, sua degradação pode favorecer o escurecimento não enzimático, e causar sabor estranho. Além disso o ácido ascórbico é um importante indicador de qualidade, pois, sendo uma vitamina termolábel, sua presença no alimento, após o processamento, indica que provavelmente os demais nutrientes também estão sendo preservados (Cardello et al., 1993/94).

Condições de campo, cultivar, maturidade, estocagem pós-colheita e o processamento afetam a concentração de ácido ascórbico em morangos. A fruta fresca é considerada fonte desta vitamina, fornecendo de 50 a $90 \mathrm{mg} / 100 \mathrm{~g}$, podendo estes valores variarem com diferentes cultivares e condições de cultivo (Morris \& Sistrunk, 1991).

A possibilidade do uso de geléia com alto teor de ácido ascórbico como suplementação alimentar para crianças foi avaliado por Viberg et al. (1997). Tem sido sugerido a adição de ácido ascórbico em geléias para aumentar seu valor nutricional. Freedman \& Francis (1984), estudando o efeito da adição de ácido ascórbico na cor de diferentes tipos de geléias verificaram que as geléias de morango apresentaram maior nível de escurecimento e degradação de pigmentos com adição desta vitamina.

Segundo Viberg et al. (1997), trabalhando com o processamento de geléias de amoras pretas verificaram que após 13 meses $60 \%$ do ácido 
ascórbico foi retido quando a geléia foi estocada a $8^{\circ} \mathrm{C}$ e $40 \%$ foi retido quando a geléia foi estocada a $37^{\circ} \mathrm{C}$.

Segundo Chichester (1982), o ácido ascórbico tem um efeito negativo na estabilidade dos pigmentos. Nos xaropes de morango, a adição do ácido ascórbico aumentou a razão da degradação das antocianinas e causou uma variação maior nos valores de Hunter, resultando um aumento significativo no escurecimento.

\subsubsection{Uso de aditivos}

Segundo Simão (1985), aditivo intencional é toda substância dotada ou não de valor nutritivo, adicionada ao alimento com finalidade de impedir alterações, manter, conferir ou intensificar seu aroma, cor, sabor, modificar ou manter seu estado fisico geral ou exercer qualquer ação exigida para uma boa tecnologia de fabricação de alimentos.

Diferentes circunstâncias justificam o uso de aditivos nos alimentos, e sempre resultam em muitas vantagens para o consumidor. Os aditivos melhoram e estabilizam o valor nutricional dos alimentos, aumentando a qualidade dos produtos, que assim poderão ser transportados a longas distâncias e estocados com segurança. Reduzem significativamente a deterioração e as perdas indesejáveis na elaboração dos alimentos, além de estender sua vida útil, reduzindo os custos finais de produção. Proporcionam melhorias no sabor, aroma e textura dos alimentos ( Pavanello, 1990). 
O ácido sórbico é o único ácido orgânico insaturado produzido sinteticamente permitido como conservador em alimentos. Em face de sua característica neutra no sabor, é recomendável para o uso em bebidas e sucos, em contrastes aos benzoatos, os quais alteram o sabor. São eficientes no controle de fungos e leveduras e poucos eficientes no controle de bactérias. $O$ ácido sórbico é ligeiramente solúvel em água $(0,16 \mathrm{~g} / 100 \mathrm{ml}$ $\mathrm{H}_{2} \mathrm{O}$ ), e o sal de potássio é bastante solúvel $\left(139 \mathrm{~g} / 100 \mathrm{ml} \mathrm{a} 20^{\circ} \mathrm{C}\right) . \mathrm{O} \mathrm{pH}$ ótimo de atuação estende-se até o pH 6,0 (Araújo, 1990).

O sorbato de potássio deve ser utilizado em produtos processados pelo calor após o tratamento térmico, evitando perdas por sublimação. A sua ação inibidora está relacionada com a incapacidade dos microrganismos afetados de metabolizarem estrutura química alifática contendo sistema diene alfa-insaturado. A presença da estrutura diene do ácido sórbico interfere com as desidrogenases celulares, as quais participam da oxidação de ácidos graxos. Este efeito não é estendido aos animais superiores, e evidências indicam que o ácido sorbico e derivados são metabolizados de maneira idêntica aos ácidos graxos (Araújo, 1990).

Os aditivos acidulantes são substâncias que comunicam gosto azedo aos produtos. O gosto azedo comunicado pelos acidulantes, faz com que 
estes sejam empregados como recursos para melhoria de sabores. A ação dos ácidos atende os seguintes objetivos: acentua o gosto agridoce, atua como conservador, retiram e seqüestram metais prejudiciais que aceleram a deterioração da cor e sabor, melhoram a textura e sabor em geléias e gelatinas, causam a inversão dos açúcares evitando sua cristalização e estabilizam o ácido ascórbico (Simão, 1985; Evangelista, 1992). Em geléias o ácido cítrico é utilizado em quantidades suficientes para obter o efeito desejado ( Soler, 1991).

A complexação metálica dos pigmentos de morango tem sido estudada por vários autores. $\mathrm{O}$ pigmento cianidina-3-monoglucosideo (C3MG) tem dois grupos fenólicos vicinais, que podem ser complexados com íons metálicos. Sistrunk \& Cash (1970), demonstraram que a cor vermelha de purês de morango era preservada a $50^{\circ} \mathrm{C}$ por 24 horas pela adição de cloreto de alumínio $\left(\mathrm{ALCL}_{3}\right)$, cloreto de estanho $\left(\mathrm{SnCL}_{4}\right)$; esses íons metálicos, especialmente o cloreto de estanho preveniram a oxidação do ácido ascórbico. Pouca mudança na cor do purê ocorre quando o cloreto de alumínio é adicionado a um $\mathrm{pH}$ de 3,0 a 3,4, porém na presença de cloreto de estanho $\left(\mathrm{Sn}^{2+}\right)$ e estânico $\left(\mathrm{Sn}^{4+}\right)$, uma cor púrpura vermelha estável se desenvolve. Segundo Kozup et al. (1980) adicionando bissulfito de sódio (80 a 160 p.p.m), ácido cítrico (0,2 a 0,5\%), cloreto de estanho (100 a 400 p.p.m) e EDTA (200 a 400 p.p.m) em purê de morango para a elaboração de geléias evitou-se a perda da cor vermelha após o processamento. Andreotti et al. (1973) estudaram a estabilização da cor em geléias de morango em escala industrial utilizando ions alumínio e estanho e observaram a formação de um 
forte complexo colorido metal-antocianina que mantinha a cor das geléias após o processamento.

É permitido o uso de no máximo $0,0025 \%$ de cloreto de estanho em geléias segundo a legislação brasileira (Brasil, 1988). 


\section{MATERIAL E MÉTODOS}

As atividades desta pesquisa foram conduzidas no laboratório do Departamento de Ciência e Tecnologia Agroindustrial da Escola Superior de Agricultura "Luiz de Queiroz"- USP- Campus de Piracicaba.

\subsection{Matéria-prima}

No presente trabalho foram utilizadas as variedades de morangos Guarani e Oso Grande. As variedades de morango foram colhidas manualmente no mês de outubro de 1995. Os morangos foram imediatamente após a colheita transportados para o laboratório do Departamento do Departamento de Ciência e Tecnologia Agroindustrial da Escola Superior de Agricultura "Luiz de Queiroz".

Foram recebidos no laboratório lotes de $20 \mathrm{Kg}$ de morango (Fragaria $\mathrm{X}$ ananassa Duch.) de cada uma das variedades em estudo, provenientes da cidade de Jarinu (região de Atibaia), Estado de São Paulo, através de doação direta do produtor, contactado com a colaboração de pesquisadores do Instituto Agronômico de Campinas ( IAC). 
As variedades Guarani e Oso Grande foram selecionadas para a realização do presente trabalho de pesquisa, por se tratarem de variedades em fase de implantação no Estado de São Paulo, não estando, até então, incluídas em pesquisa a nível de processamento e por possuírem características favoráveis para a elaboração de geléias conforme resultados obtidos em testes preliminares.

Todo material foi processado dentro de um período máximo de 48 horas, após seu recebimento.

Os frutos foram selecionados para o processamento ,ou seja, não continham frutos machucados ou deteriorados, apresentavam ótimas condições para o consumo "in natura" e estavam no seu ponto ótimo de maturação quando tinham portanto, as melhores características fisicas, químicas e sensoriais.

\subsection{Análises de Caracterização da Matéria-prima}

\subsubsection{Análises físicas}

a) Rendimento: Para as determinações de rendimento da matériaprima, foram utilizadas amostras de $1000 \mathrm{~g}$ de frutos tomadas aleatoriamente dos lotes do material. 
Inicialmente, os morangos foram pesados em balança semi-analítica, a seguir limpos, lavados e drenados por 15 minutos e, então, novamente pesados. Os resultados foram expressos em porcentagem do peso da matériaprima pronta para o processamento em relação ao peso original da matériaprima.

b) Textura: Para as determinações da textura dos frutos foi utilizado o "Texture Testing System" (texturômetro), modelo TP-1 acloplado a um registrador automático de variações de força, operando com célula-padrão de compressão e cisalhamento $\mathrm{CS}-1$, com 10 lâminas de 1/8 polegadas de espessura e ângulo $90^{\circ}$. O instrumento estava provido de um sensor eletrônico de $300 \mathrm{lbf}$ e a velocidade de descida do pistão foi de $20 \mathrm{~cm} / \mathrm{minuto}$.

As amostras foram anteriormente pesadas (50 $\mathrm{g}$ de morangos inteiros sem cálice) e colocados ao acaso na célula-teste. Os resultados foram apresentados em libra força/g de amostra.

c) Suculência: para as determinações de suculência dos frutos foi utilizado o "Texture Testing System", empregando a célula-padrão de suculometria CR-1 ( succulometer cell). $\mathrm{O}$ instrumento estava provido de um anel de $3.000 \mathrm{lbf}$ e a velocidade de descida do pistão foi de $20 \mathrm{~cm} / \mathrm{minuto}$.

As amostras foram previamente pesadas (50g de morangos inteiros sem os cálices) e colocadas ao acaso na célula-teste, sendo o volume de suco liberado, coletado em proveta graduada de $50 \mathrm{ml}$. Os dados apresentados 
correspondem ao volume de suco liberado $(\mathrm{ml})$ por grama de amostra, quando submetida a uma força máxima de compressão, pelo tempo de 2 minutos.

Todas as determinações físicas foram efetuadas com 2 repetições em amostras tomadas aleatoriamente dos lotes das duas variedades de matériaprima.

\subsubsection{Análises químicas}

a) Ácido ascórbico: Foi determinado por extração em ácido oxálico e titulação, segundo Método de Tillmans modificado por Leme Junior \& Malavolta (1950).

Amostras de $10 \mathrm{~g}$ foram trituradas em liqüidificador com $50 \mathrm{ml}$ de ácido oxálico a 4:1000, durante três minutos. A seguir, a mistura foi passada para um balão volumétrico de $100 \mathrm{ml}$. O copo do liqüidificador foi lavado com porções de $20 \mathrm{ml}$ de ácido oxálico, que eram adicionadas ao balão volumétrico de $100 \mathrm{ml}$, até completar o volume. $\mathrm{O}$ conteúdo do balão foi filtrado e $2 \mathrm{ml}$ deste foram pipetados para um erlenmeyer de $125 \mathrm{ml}$ e adicionado $50 \mathrm{ml}$ de água destilada, que a seguir foi titulado sob agitação, com solução corante de 2,6 diclorofenolindofenol. Os teores de ácido ascórbico das amostras foram calculados tomando-se por base um padrão de ácido ascórbico, previamente determinado. Os resultados foram expressos em $\mathrm{mg}$ de ácido ascórbico por $100 \mathrm{~g}$ da amostra. 
b) Acidez total titulável : Foi determinada segundo método de referência número 22060 da "Association of Official Analytical Chemists" AOAC ( 1975), conforme descrito a seguir:

Amostras de $10 \mathrm{~g}$ de frutas foram trituradas com $90 \mathrm{ml}$ de água destilada e, a seguir, tituladas rapidamente e sob agitação com solução de $0,1 \mathrm{~N}$ de $\mathrm{NaOH}$, até $\mathrm{pH}=7,0$; a partir deste ponto a titulação prosseguiu lentamente até $\mathrm{pH}=8,1$, no qual ocorre a cor de viragem (laranja para púrpura). Os resultados são expressos em porcentagem do ácido presente em maior quantidade na amostra em estudo, que no caso do morango é o ácido cítrico.

c) pH: Foi determinado em potenciômetro Alphalab, modelo PA-200. Os resultados são expressos em unidades de $\mathrm{pH}$.

d) Sólidos solúveis (graus Brix): Foi determinado em refratômetro Atago, modelo $\mathrm{N}-1$. Os resultados são expressos em porcentagem (massa/massa).

Todas as análises químicas foram efetuadas com duas repetições utilizando amostras tomadas aleatoriamente dos lotes das duas variedades de morango. 


\subsection{Processamento}

As operações utilizadas no processamento de geléia comum e dietética são descritas à seguir.

\subsubsection{Geléia comum}

\section{A. Formulação básica}

A formulação básica utilizada (selecionada em testes preliminares) para obtenção de géleia comum foi a seguinte:

Para cada $1,5 \mathrm{Kg}$ de polpa de morango utilizou-se:

$-1,5 \mathrm{Kg}$ de açúcar cristal

- 10 g de pectina de alto grau de esterificação ( Marca Braspectina-S.A) tipo 8105 -com poder poder geleificante de $150^{\circ}$.

- Ponto final de cocção: $67^{\circ} \mathrm{Brix}$ (variedade Guarani) e $64^{\circ} \mathrm{Brix}$ (variedade Oso Grande).

\section{B. Procedimento}

As operações utilizadas para a obtenção de geléia comum estão indicadas na Figura 1. Após recebimento dos lotes de morango no laboratório, os frutos foram imediatamente selecionados, lavados e drenados por cerca de 15 minutos, e em seguida os cálices eram removidos. $6 \mathrm{~kg}$ de morangos foram 
despolpados em despolpadeira ITAMETAL, modelo 0,25df, utilizando peneira de 0,6 mm. Após o despolpamento foram pesadas porções de $1,5 \mathrm{~kg}$ de polpa de morango, às quais foram adicionadas açúcar e pectina. Homogeneizou-se para evitar formação de gnumos e concentrou-se em tachos abertos à pressão atmosférica até atingir $67^{\circ}$ Brix (Variedade Guarani) e $64^{\circ}$ (Variedade Oso Grande). Os tratamentos aplicados estão esquematizados na Figura 2.

\section{Tratamentos para a obtenção de geléia comum}

\section{Tratamento 1: Morango + Sacarose + Pectina}

Depois de lavados, drenados, pesados e despolpados, um lote de 1,5 $\mathrm{kg}$ de polpa de morango foi colocado em tacho aberto. Em seguida, adicionouse a pectina, o açúcar e concentrou-se à pressão atmosférica até atingir $67^{\circ} \mathrm{Brix}$ (variedade Guarani) e $64^{\circ}$ Brix (variedade Oso Grande). A geléia foi envasada à quente em copos de vidro, que foram em seguida recravados (tampas metálicas), resfriados e armazenados à temperatura ambiente. Este tratamento constituiu o controle, ou seja, os constituintes presentes são os da formulação básica para a obtenção de geléia comum.

\section{Tratamento 2: Morango + Sacarose + Pectina + Ácido cítrico}

Este tratamento seguiu o mesmo procedimento do tratamento 1, porém com adição de quantidade adequada de ácido cítrico até se atingir $\mathrm{pH}$ 3,3 . 


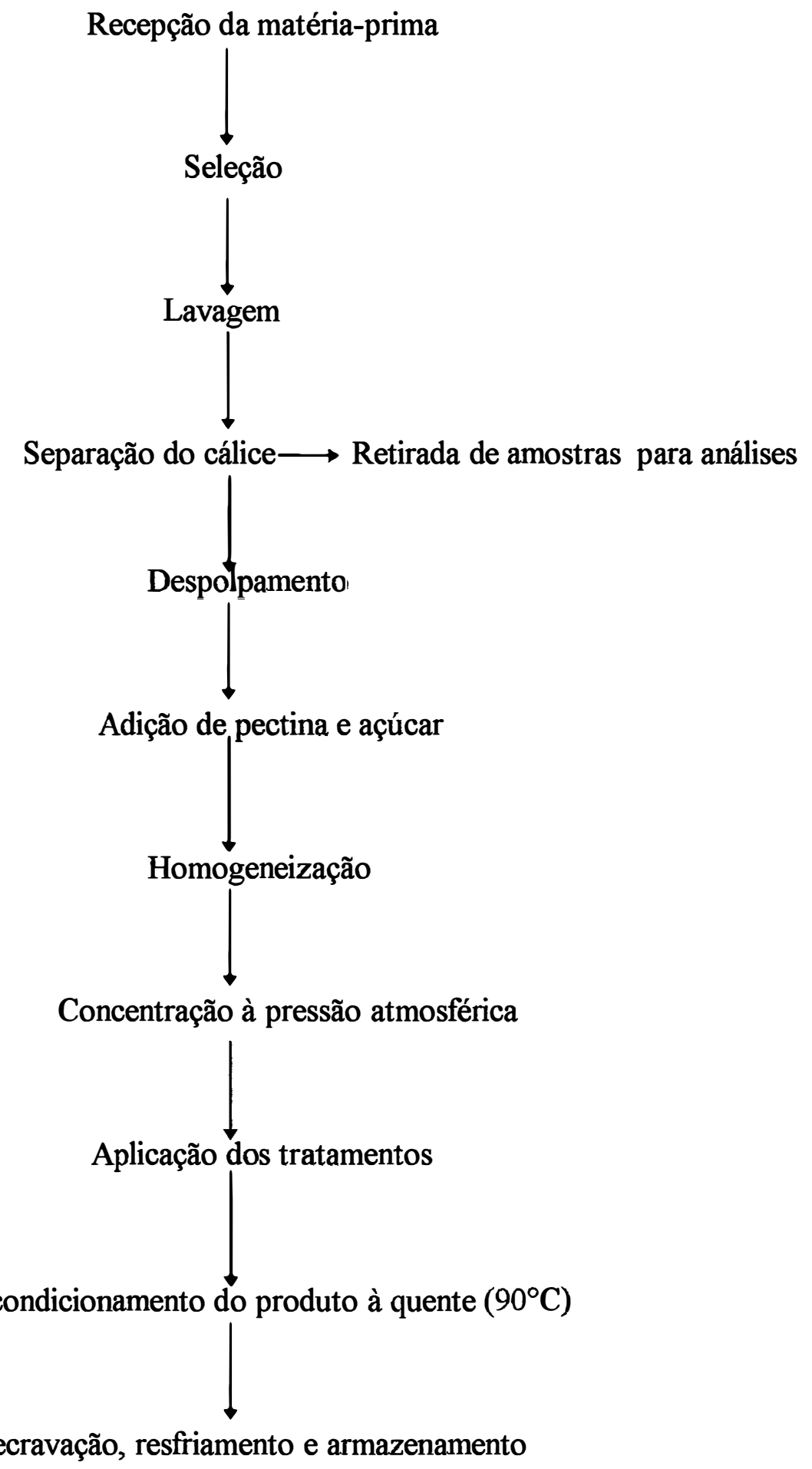

Figura 1. Fluxograma das operações utilizadas no processamento de geléia comum. 


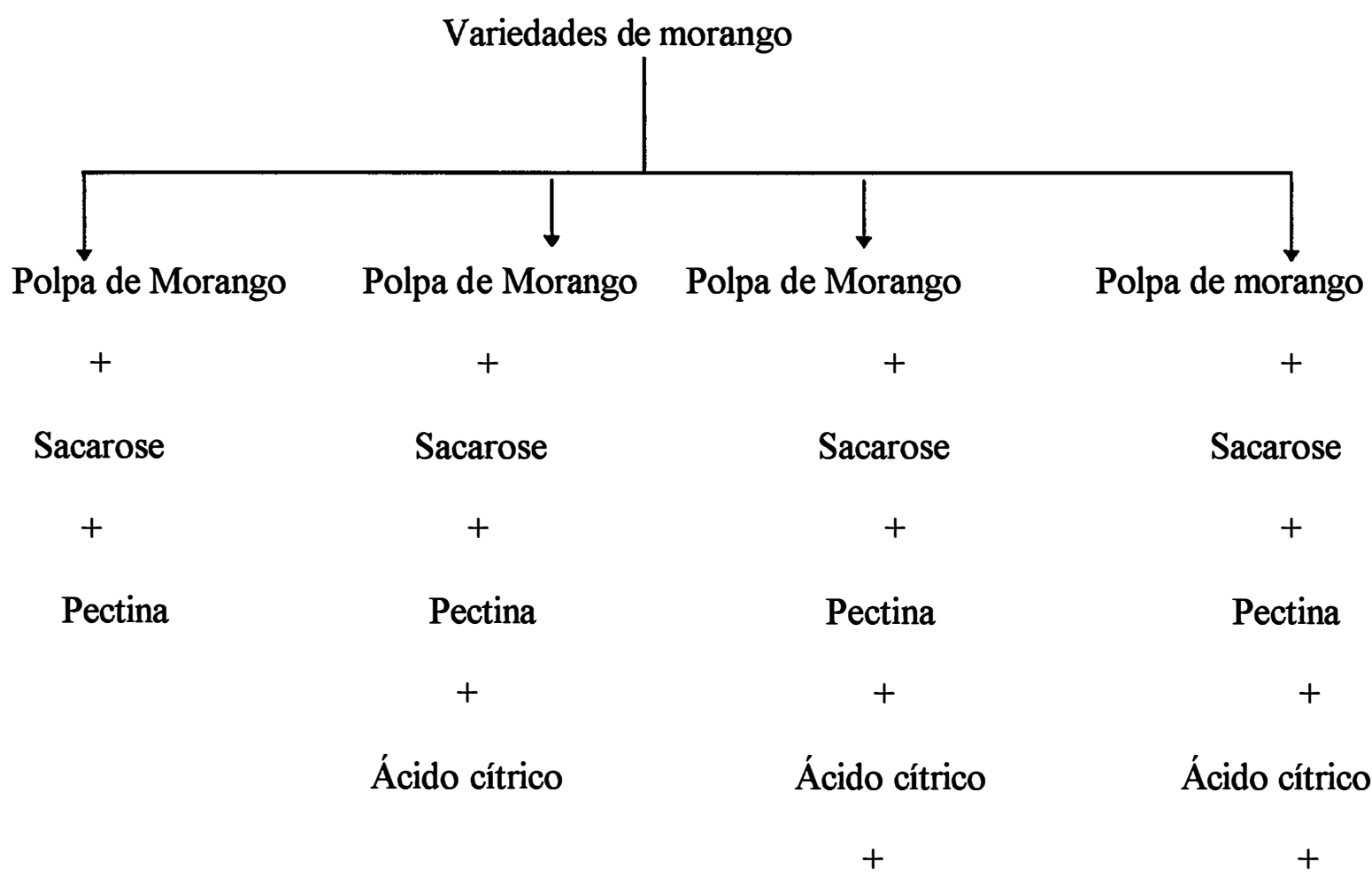

Sorbato de Potássio Sorbato de Potássio

$+\quad+$

Cloreto de estanho Cloreto de Estanho

$+$

Ácido ascórbico

Figura 2. Esquema dos tratamentos aos quais as polpas de morangos de cada variedade foram submetidas para obtenção de geléias comuns. 
Tratamento 3: Morango + Sacarose + Pectina + Ácido cítrico + Sorbato de Patássio + Cloreto de Estanho

Este tratamento seguiu o mesmo procedimento do tratamento 2, porém com adição de $0,1 \%$ de sorbato de potássio e $0,0025 \%$ de cloreto de estanho (em relação ao peso de polpa). O sorbato de potássio foi utilizado como agente anti-fúngico e o cloreto de estanho como estabilizante químico da cor. As quantidades adicionadas estão dentro do limite permitido pela legislação brasileira (Brasil, 1988).

Tratamento 4: Morango + Sacarose + Pectina + Ácido cítrico + Sorbato de Patássio + Cloreto de Estanho + Ácido ascórbico

Este tratamento seguiu o mesmo procedimento do tratamento 3, porém com adição de $0,03 \%$ ácido ascórbico (em relação ao peso de polpa). $\mathrm{O}$ ácido ascórbico foi adicionado como antioxidante e para enriquecimento nutricional do produto. A quantidade adicionada esta dentro do limite permitido pela legislação brasileira (Brasil, 1988).

\subsubsection{Geléia dietética}

\section{A. Formulação básica}

A formulação básica utilizada (selecionada em testes preliminares) para obtenção de geléia dietética foi a seguinte:

Para $1,5 \mathrm{Kg}$ de polpa de morango utilizou-se: 
- Sorbitol: $30 \mathrm{~g}$

- Steviosideo ( Stevia Cristal- Ingá Stevia Industrial S.A): 0,66 g

- Pectina de baixa metoxilação ( Braspectina-S.A ) tipo 8002: $3 \mathrm{~g}$

- Fosfato tri-cálcio: $0,39 \mathrm{~g}$

- Água: $1.466 \mathrm{~g}$

-Ponto final de coç̧ão: 15 a $17^{\circ}$ Brix

\section{B. Procedimento}

As operações utilizadas para a obtenção de geléia dietética estão indicadas na Figura 3. Após recebimento dos lotes de morango no laboratório, os frutos foram imediatamente selecionados, lavados e drenados por cerca de 15 minutos, e em seguida os cálices eram removidos. $6 \mathrm{~kg}$ de morangos de cada variedade foram despolpados em despolpadeira ITAMETAL, modelo $0,25 \mathrm{df}$, utilizando peneira de $0,6 \mathrm{~mm}$. Após o despolpamento foram pesadas porções de $1,5 \mathrm{~kg}$ de polpa de morango, às quais foram adicionadas sorbitol $\mathrm{e}$ pectina. Homogeneizou-se para evitar formação de grumos e concentrou-se em tachos abertos à pressão atmosférica até atingir $15-17^{\circ}$ Brix. No final do processo de concentração adicionou-se a estévia e foram aplicados os tratamentos esquematizados na Figura 4. Em seguida as geléias foram acondicionadas à quente em copos de vidro, que foram recravados (com tampas metálicas) e esterilizados em água fervente por 10 minutos. 
Recepção da matéria-prima

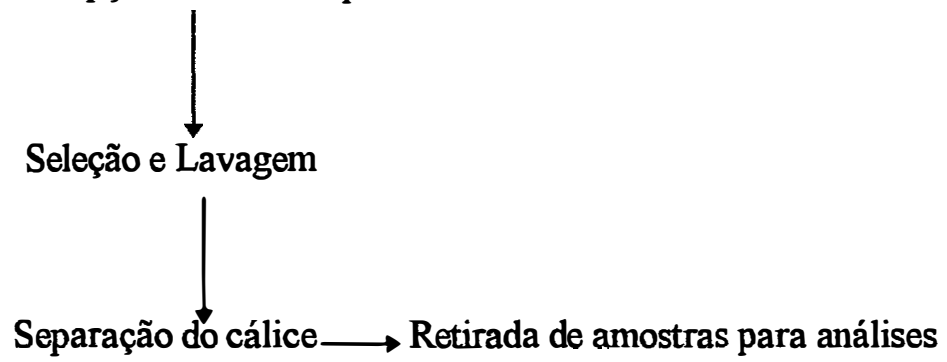

Adição de sorbitol e pectina
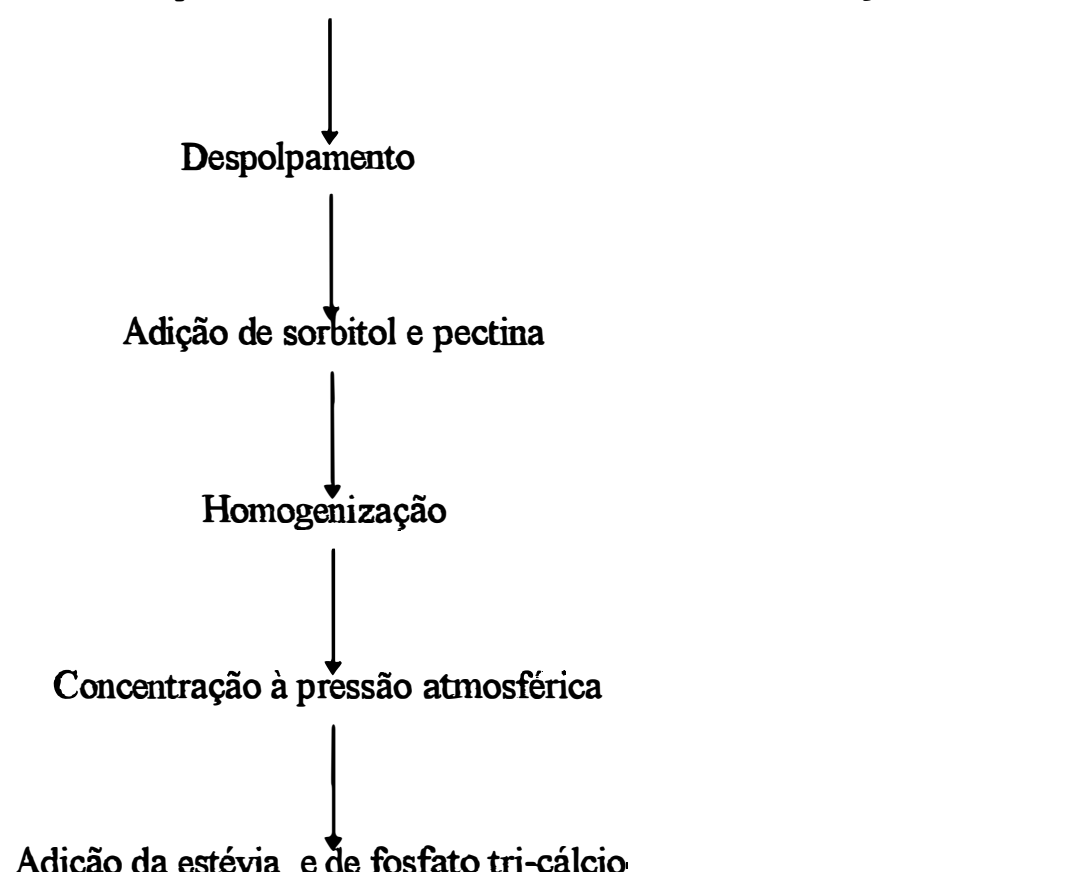

Adição da estévia e de fosfato tri-cálcio

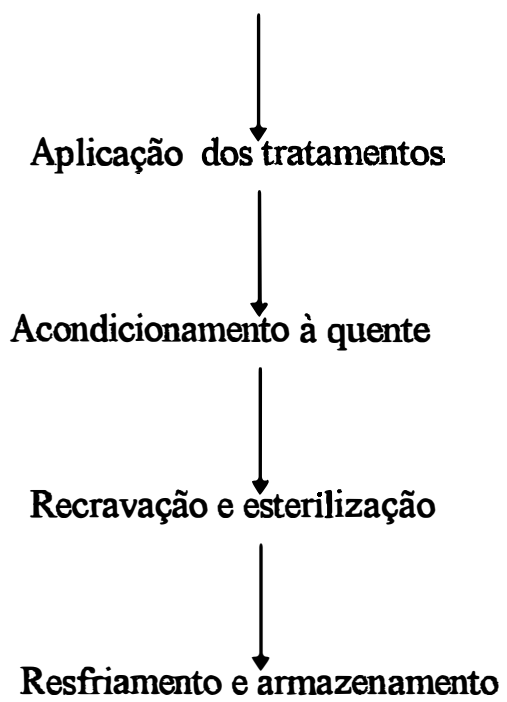

Figura 3. Fluxograma das operações utilizadas no processamento de geléia dietética 


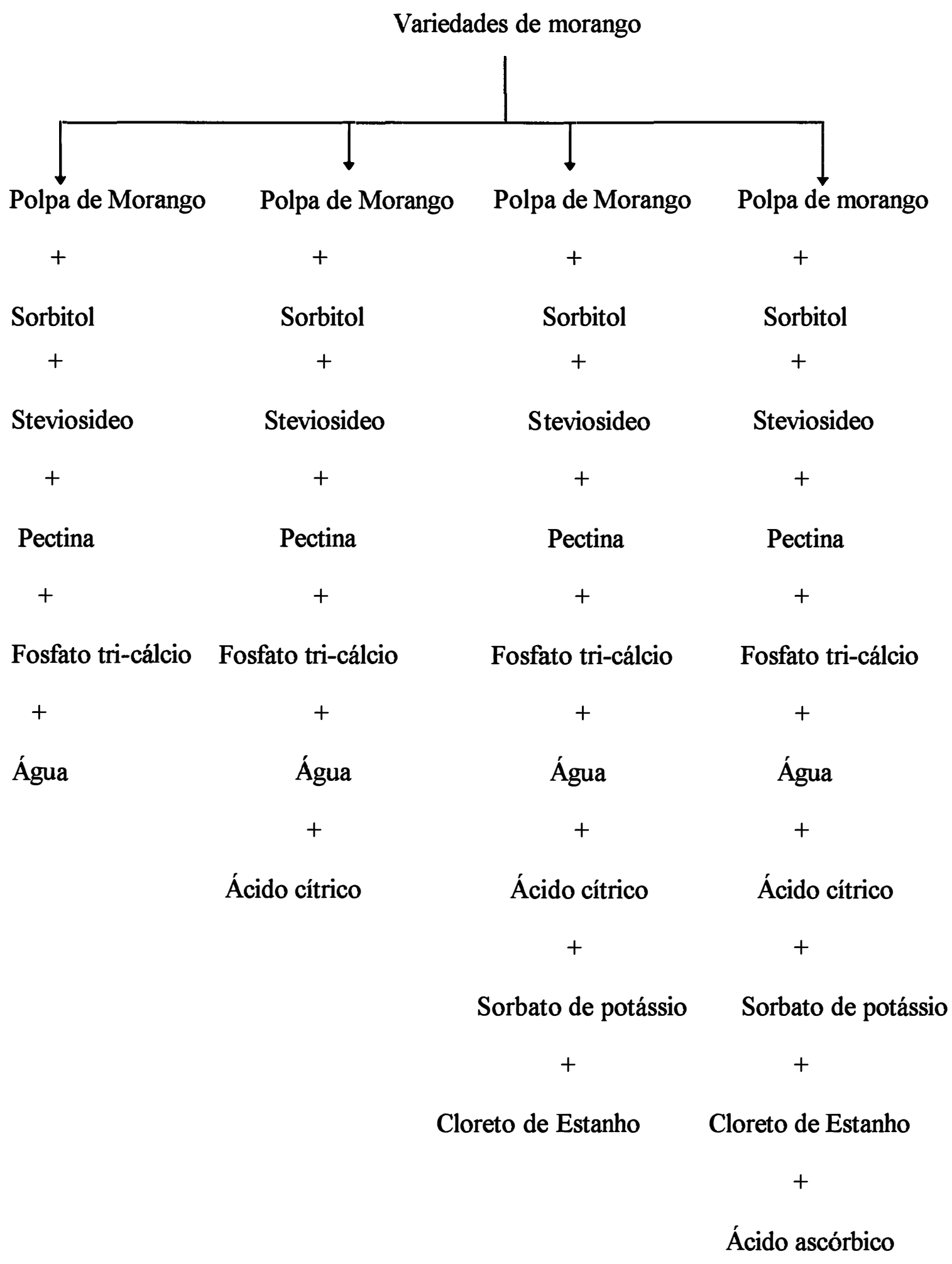

Figura 4. Esquema dos tratamentos aos quais as polpas de morangos de cada variedade foram submetidas para obtenção de geléias dietéticas. 


\section{Tratamentos para obtenção de geléia dietética}

\section{Tratamento 1: Morango + Sorbitol + Steviosideo +Pectina +Fosfato tri- cálcio + Água}

Depois de lavados, drenados, pesados e despolpados, um lote de 1,5kg de polpa de morango foi colocado em tacho aberto. Em seguida, adicionou-se a pectina e o sorbitol. Concentrou-se à pressão atmosférica até atingir $15-17^{\circ}$ Brix, adicionou-se então o steviosideo e o fosfato tri-cálcio. A geléia foi envasada à quente em copos de vidro, que foram em seguida recravados (com tampas metálicas), esterilizados ( $10 \mathrm{~min}$. em água fervente ), resfriados e armazenados à temperatura ambiente. Este tratamento constituiu o controle, ou seja, os constituintes presentes são os da formulação básica para a obtenção de geléia dietética.

\section{Tratamento 2: Morango + Sorbitol + Steviosideo +Pectina +Fosfato tri- cálcio + Água + Ácido cítrico}

Este tratamento seguiu o mesmo procedimento do tratamento 1, porém com adição de quantidade adequada de ácido cítrico para obter pH 3,2. Para a variedade Guarani não foi necessária a adição do ácido cítrico, devido ao alto teor de acidez que esta variedade apresenta.

Tratamento 3: Morango + Sorbitol + Steviosideo +Pectina +Fosfato tricálcio + Água + Ácido cítrico + Sorbato de Potássio + Cloreto de Estanho 
Este tratamento seguiu o mesmo procedimento do tratamento 2 porém com adição de $0,1 \%$ de sorbato de potássio e $0,0025 \%$ de cloreto de estanho (em relação ao peso de polpa). O sorbato de potássio foi utilizado como um agente anti-fúngico e o cloreto de estanho como estabilizante químico da cor. As quantidades adicionadas estão dentro do limite permitido pela legislação brasileira (Brasil, 1988).

Tratamento 4: Morango + Sorbitol + Steviosideo +Pectina +Fosfato tricálcio + Água + Ácido cítrico + Sorbato de Potássio + Cloreto de Estanho + Ácido ascórbico

Este tratamento seguiu o mesmo procedimento do tratamento 3, porém com adição de $0,03 \%$ ácido ascórbico (em relação ao peso de polpa). $\mathrm{O}$ ácido ascórbico foi adicionado como antioxidante e para enriquecimento nutricional do produto. A quantidade adicionada está dentro do limite permitido pela legislação brasileira (Brasil, 1988).

\subsubsection{Acondicionamento}

$\mathrm{O}$ acondicionamento foi feito à quente em copos de vidro com capacidade para $240 \mathrm{~g}$ que em seguida foram recravados com tampas metálicas. Em cada copo foram colocados $230 \mathrm{~g}$ de geléia, deixando um espaço livre de 5 $\mathrm{mm}$.

\subsubsection{Esterilização e resfriamento}


As geléias dietéticas após o acondicionamento foram esterilizadas em água fervente por dez minutos e a seguir resfriadas a temperatura ambiente. As geléias comuns após acondicionamento à quente e recravação foram, também resfriadas até a temperatura ambiente.

\subsubsection{Armazenamento}

Após o processamento as geléias foram armazenadas em prateleiras à temperatura ambiente, até serem analisadas.

\subsection{Avaliação dos produtos processados}

Para avaliar a qualidade das geléias comuns e dietéticas, assim como determinar qual variedade melhor, adaptou- se ao processamento e a eficiência dos tratamentos, foram realizadas análises físicas, químicas (aos $0,30,60,90$, 120,150 e 180 dias após o processamento) e sensoriais ( aos 30, 60 e 90 dias após o processamento).

\subsubsection{Análises físicas}

a) Vácuo: foi determinado com o auxílio de um vacuômetro "Marshaltown", em polegadas de mercúrio (pol.Hg). 
b) Peso bruto: foi utilizada balança semi-analítica (com precisão de $0,01 \mathrm{~g}$ ) para determinação do peso total (embalagem mais produto).

c) Peso líquido: foi determinado descontando do peso bruto, o peso da tampa com o vidro vazio, limpo e seco (utilizou-se balança semi-analítica com precisão de $0,01 \mathrm{~g}$ ).

\subsubsection{Análises químicas}

a) Ácido ascórbico: determinada conforme descrito no item 4.2.2.a.

b) Acidez Total Titulável: determinada conforme descrito no item 4.2 .2.b.

c) pH: determinado conforme descrito no item 4.2 .2.c.

d) Sólidos solúveis (Brix) : determinado conforme descrito no item 4.2 .2.d.

Todas as determinações físicas e químicas realizadas no produto final foram efetuadas com duas repetições em amostras tomadas aleatoriamente, dos lotes do produto processado das duas variedades em estudo. 


\subsubsection{Análise sensorial}

As amostras de geléias (comum e dietética) das duas variedades estudadas foram avaliadas subjetivamente aos 30,60 e 90 dias após o processamento, quanto ao sabor, cor e textura.

As avaliações das geléias foram feitas por uma equipe de 8 provadores, previamente selecionados e treinados para este tipo de avaliação, utilizando uma escala hedônica estruturada de nove pontos (Girardot et al., 1952; Dawson, 1964; Martin, 1973). Os modelos de fichas utilizados nestas avaliações estão apresentados nas Figuras 5, 6 e 7.

Para a avaliação da cor das geléias, as amostras devidamente codificadas foram servidas em placas de petri, as quais foram dispostas aleatoriamente em bandeja de plástico branco, colocada em local com iluminação de luz fluorescente.

Para a avaliação do sabor e textura das geléias, as amostras foram servidas em copos de plástico branco $(50 \mathrm{ml})$, codificados com números aleatórios de três dígitos em cabines individuais iluminadas com luz vermelha, para mascarar a cor dos produtos. Para melhor analisar estes atributos foram servidos biscoitos tipo água e sal.

As análises foram efetuadas sempre duas horas antes ou depois das refeições, os quais são os períodos mais adequados para realização dessas avaliações. 


\section{AVALIAÇÃO SENSORIAL}

Produto:

Nome:

Data ------/-----------

Por favor, Prove as amostras e indique a intensidade do Sabor de acordo com a escala abaixo:

\begin{tabular}{|c|c|c|c|c|c|c|c|c|c|}
\hline & Péssimo & & & & gul & & & Ótimo & Observações \\
\hline Amostras & 1 & 2 & 3 & 4 & 5 & 6 & & 9 & \\
\hline & & & & & & & & & \\
\hline & & & & & & & & & \\
\hline & & & & & & & & & \\
\hline & & & & & & & & & \\
\hline
\end{tabular}

Figura 5. Modelo de ficha utilizado na avaliação sensorial das amostras quanto ao sabor.

\section{AVALIAÇÃO SENSORIAL}

Produto:

Nome:

Data ------/-------/-----

Por favor, Observe as amostras e indique a intensidade da Cor de acordo com a escala abaixo:

\begin{tabular}{|c|c|c|c|c|c|c|c|c|c|c|}
\hline \multirow[b]{2}{*}{ Amostras } & \multirow{2}{*}{$\begin{array}{c}\text { Péssimo } \\
1\end{array}$} & \multicolumn{2}{|c|}{ Ruim } & \multicolumn{3}{|c|}{ Regular } & \multicolumn{2}{|c|}{ Bom } & \multirow{2}{*}{$\begin{array}{c}\text { Ótimo } \\
9\end{array}$} & \multirow[t]{2}{*}{ Observações } \\
\hline & & 2 & 3 & 4 & 5 & 6 & & 8 & & \\
\hline & & & & & & & & & & \\
\hline & & & & & & & & & & \\
\hline & & & & & & & & & & \\
\hline & & & & & & & & & & \\
\hline
\end{tabular}

Figura 6. Modelo de ficha utilizado na avaliação sensorial das amostras quanto à cor. 


\section{AVALIAÇÃO SENSORIAL}

Produto:

Nome:

Data

$-/-----/---$

Pr favor, Prove as amostras e indique a intensidade da Textura de acordo com a escala abaixo:

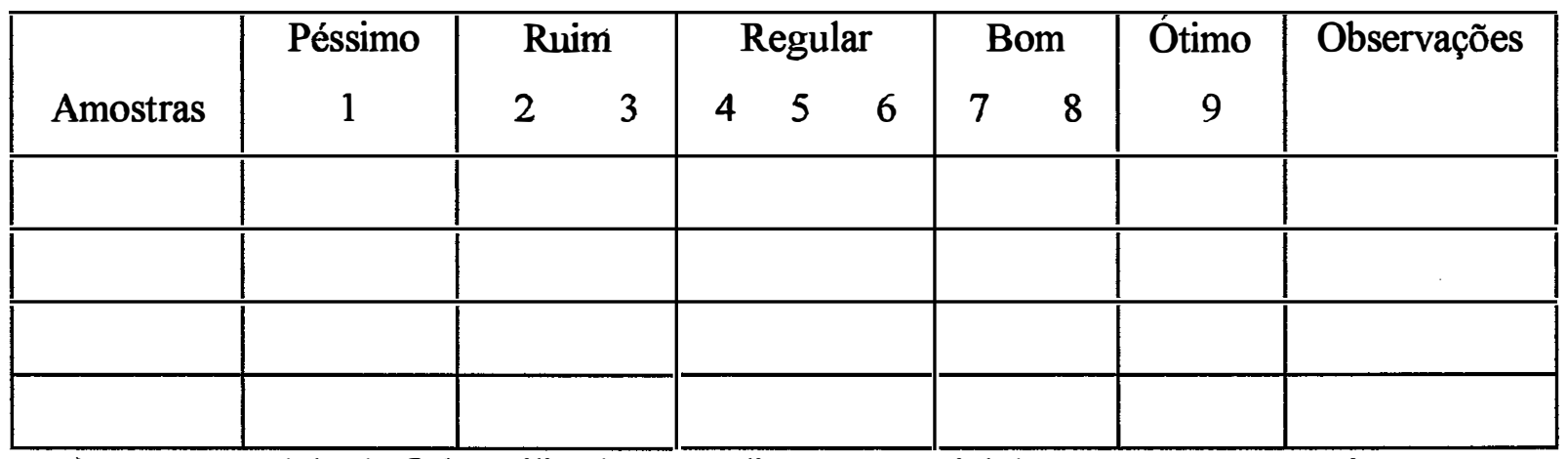

Figura 7. Modelo de ficha utilizado na avaliação sensorial das amostras quanto à textura.

\subsubsection{Análise Estatística}

\section{a) Matéria-prima}

Os resultados da matéria-prima foram apresentados através de médias com seus respectivos desvios padrões, correspondente às duas repetições.

\section{b) Produtos}

Os dados dos produtos processados foram analisados pelo delineamento de blocos casualizados com quatro tratamentos e duas repetições para cada variedade testada, com a utilização do teste de Tukey (5\%) ( Gomes, 1973a; Banzatto \& Kronka, 1995). 
Todas as médias possuíam o mesmo número de repetições; os tratamentos foram designados às parcelas de forma casual, sendo essa casualização feita dentro de cada bloco (épocas de avaliação) (Banzatto \& Kronka, 1995).

As médias obtidas na avaliação sensorial foram analisadas pelo delineamento de blocos casualizados com quatro tratamentos e oito repetições para cada produto testado, com utilização do teste de tukey (5\%). Cada provador foi designado como sendo um bloco. 


\section{RESULTADOS E DISCUSSÃO}

\subsection{Caracterização da matéria-prima}

\subsubsection{Análises físicas}

Os resultados da avaliação objetiva dos atributos físicos (textura, suculência e rendimento) estão apresentados na Tabela 1.

Tabela 1. Características físicas das variedades de morango "in natura" (matéria-prima).

\begin{tabular}{l|c|c}
\hline $\begin{array}{c}\text { Características } \\
\text { Físicas }\end{array}$ & $\begin{array}{c}\text { Média das Análises } \\
\text { Oso Grande }\end{array}$ & $\begin{array}{c}\text { (2 repetições ) } \\
\text { Guarani }\end{array}$ \\
\hline Textura (lbf/g) & $0,93 \pm 0,076$ & $0,84 \pm 0,024$ \\
Suculência (ml/g) & $0,50 \pm 0,007$ & $0,50 \pm 0,070$ \\
Rendimento (\%) & 98,6 & 96,5 \\
\hline
\end{tabular}

Segundo Hudson et al. (1975), a suculência é um atributo físico dos frutos inversamente relacionada com a textura, ou seja quanto mais firme menos suculento ele será, em termos de partes comestíveis. 
Comparando as duas variedades estudadas (Tabela 1), verifica-se que a variedade Oso Grande apresentou uma textura mais firme que a variedade Guarani, porém ambas apresentaram a mesma suculência, contrariando assim os estudos feitos por Hudson et al. (1975).

De acordo com Boume (1982), a finmeza é um importante fator na qualidade das frutas. Muitas frutas são colhidas a um certo nível de firmeza, que é utilizado para estabilizar um grau de qualidade e preço no mercado. A medida que os frutos amadurecem ocorre a degradação das substâncias pécticas, o que pode ser facilmente observado pelo amolecimento da polpa das mesmas ( Leme Jr., 1968).

Os rendimentos das duas variedades estudadas mostraram que para cada $1000 \mathrm{~g}$ de morango "in natura" $965 \mathrm{~g}$ da Guarani e $986 \mathrm{~g}$ da Oso Grande foram utilizadas para processamento, o que mostra um alto rendimento e ótima qualidade da matéria-prima, com ausência de frutos amassados, machucados ou deteriorados por microrganismos.

\subsubsection{Análises químicas}

Na Tabela 2, são apresentados os resultados das determinações de ácido ascórbico, acidez total titulável, $\mathrm{pH}$ e sólidos solúveis (Brix) da matéria-prima.

Os teores de ácido ascórbico encontrados estão de acordo com dados obtidos por Skrede $(1980,1982)$, que estudou diversas variedades de morango, 
algumas delas para obtenção de geléias; Morris \& Sistrunk (1991) encontraram teores variando de 50 a $90 \mathrm{mg} / 100 \mathrm{~g}$ de polpa de morango.

Tabela 2. Características químicas das variedades de morango "in natura" (matéria-prima).

\begin{tabular}{l|c|c}
\hline \multicolumn{1}{c|}{$\begin{array}{c}\text { Características } \\
\text { Químicas }\end{array}$} & $\begin{array}{c}\text { Média das Análises } \\
\text { Oso Grande }\end{array}$ & $\begin{array}{c}\text { ( 2 repetições ) } \\
\text { Guarani }\end{array}$ \\
\hline Ácido ascórbico(mg/100g) & $69,04 \pm 3,60$ & $70,71 \pm 1,01$ \\
Acidez Total Titulável (\%) & $0,67 \pm 0,10$ & $0,81 \pm 0,06$ \\
pH & $3,81 \pm 0,015$ & $3,46 \pm 0,034$ \\
Sólidos Solúveis (Brix) & $8,62 \pm 0,593$ & $5,26 \pm 0,503$ \\
\hline
\end{tabular}

Acidez e pH são fatores de extrema importância na aceitação de um produto, pois sendo extremamente ácido não é possível de ser consumido, principalmente no mercado nacional, cujo o hábito é de produtos pouco ácidos ( Albregts \& Howard, 1978).

As variedades estudadas apresentaram teores de acidez semelhantes aos encontrados por Richards (1996), que constatou 0,77 e 0,83\% respectivamente para as variedades Chandler e Reiko.

A variedade Guarani (Tabela 2) apresentou valores de $\mathrm{pH}$ inferiores à variedade Oso Grande, o que pode ser confirmado pelos teores de acidez total titulável.

Os valores de $\mathrm{pH}$ obtidos para a variedade Guarani foram em semelhantes aos encontrados por Costell et al. (1987); Skrede et al. (1993) encontrou valores 
entre 3,34 a 3,57; Richards (1996) estudando as variedades Chandler e Reiko encontrou valores entre 3,41 a 3,50 e Passos (1989) que estudou a variedade Guarani encontrou o valor médio de 3,45. Já para a variedade Oso Grande os valores determinados foram superiores aos encontarados na literatura.

Pela Tabela 2 observa-se também que as variedades Guarani e Oso Grande apresentaram teores de sólidos solúveis variando de 5,26 a 8,62 respectivamente. Os valores encontrados estão de acordo com Skrede (1980) que estudou 12 variedades e encontrou valores de 8 a 11\%; Costell et al. (1987) estudaram 3 variedades e encontraram valores de 8 a 11\%; Richards (1996) encontrou valores de 8 a $10 \%$ e Berbari (1992) estudando as variedades Chandler e Reiko encontrou valores de 8 a $11 \%$. Comparando as duas variedades (Tabela 2), verifica-se que a variedade Guarani apresentou um teor médio de sólidos solúveis bem inferior a variedade Oso Grande ( 5,26 a 8,62 respectivamente ).

\subsection{Caracterização do produto final}

\subsubsection{Geléia Comum}

\subsubsection{Análises físicas}

As análises fisicas efetuadas, envolvendo determinações do peso bruto dos e peso líquido, nos períodos de 0 a 180 dias de armazenamento à temperatura ambiente, mostraram resultados normais, sem variações significativas em relação 
às geléias processadas com a variedade Oso Grande (Tabelas 3 e 4); para as geléias elaboradas com a variedade Guarani (Tabelas 3 e 4) ocorreram diferenças significativas em relação às épocas de avaliação (30 e 60 dias), porém sem maiores consequências para o controle de qualidade dos produtos.

Tabela 3. Peso bruto ( $\mathrm{g}$ ) das geléias comuns de morango das duas variedades durante armazenamento.

\begin{tabular}{|c|c|c|c|c|c|c|c|c|c|c|}
\hline \multirow[b]{2}{*}{$\begin{array}{c}\text { Tempo em } \\
\text { dias }\end{array}$} & \multirow[b]{2}{*}{ T1 } & \multicolumn{2}{|c|}{ Guarani } & \multirow[b]{2}{*}{ T4 } & \multirow[b]{2}{*}{ Médias } & \multicolumn{4}{|c|}{ Oso Grande } & \multirow[b]{2}{*}{ Médias } \\
\hline & & T2 & T3 & & & T1 & T2 & T3 & T4 & \\
\hline 0 & 331,81 & 349,24 & 338,72 & 344,90 & $341,17^{A B}$ & 347,90 & 348,95 & 346,05 & 349,45 & $348,08^{A}$ \\
\hline 30 & 353,49 & 346,25 & 339,27 & 345,00 & $346,03^{A}$ & 349,05 & 343,90 & 349,55 & 349,00 & $347,87^{A}$ \\
\hline 60 & 340,87 & 340,10 & 337,97 & 327,43 & $336,59^{8}$ & 344,95 & 347,45 & 348,55 & 349,35 & $347,57^{A}$ \\
\hline 90 & 328,29 & 334,10 & 347,70 & 348,00 & $339,52^{\text {AB }}$ & 339,50 & 350,50 & 346,00 & 348,50 & $346,22^{A}$ \\
\hline 120 & 354,78 & 335,70 & 342,70 & 336,70 & $342,47^{\text {AS }}$ & 341,20 & 347,30 & 350,05 & 347,80 & $346,58^{A}$ \\
\hline 150 & 348,65 & 336,50 & 336,84 & 337,25 & $340,06^{A B}$ & 347,05 & 348,95 & 348,80 & 347,75 & $348,13^{A}$ \\
\hline 180 & 345,61 & 338,25 & 343,29 & 352,90 & $345,01^{\text {AB }}$ & 349,90 & 341,80 & 348,25 & 346,75 & $346,67^{A}$ \\
\hline Médias & $343,50^{A}$ & $340,02^{A}$ & $340,94^{A}$ & $341,74^{A}$ & & $345,70^{A}$ & $346,97^{A}$ & $348,17^{A}$ & $348,37^{A}$ & \\
\hline F( Epocas) & $2,75^{\star \star}$ & & & & & $1,20 \mathrm{n} . \mathrm{s}$ & & & & \\
\hline F ( Trat) & $2,21 \mathrm{n} . \mathrm{s}$ & & & & & $6,43 n . s$ & & & & \\
\hline
\end{tabular}

$\mathrm{T} 1, \mathrm{~T} 2, \mathrm{~T} 3, \mathrm{~T} 4=$ tratamentos de processamento n.s = não significativo ** = significativo a nível de $1 \%$

As médias seguidas das mesmas letras não diferem entre si, ao nível de $5 \%$ de probabilidade 
Tabela 4. Peso liquído (g) das geléias comuns de morango das duas variedades durante armazenamento.

\begin{tabular}{|c|c|c|c|c|c|c|c|c|c|c|}
\hline \multirow[b]{2}{*}{$\begin{array}{c}\text { Tempo em } \\
\text { dias }\end{array}$} & \multirow[b]{2}{*}{ T1 } & \multicolumn{2}{|c|}{ Guarani } & \multirow[b]{2}{*}{ T4 } & \multirow[b]{2}{*}{ Médias } & \multirow[b]{2}{*}{ T1 } & \multicolumn{2}{|c|}{ Oso Grande } & \multirow[b]{2}{*}{ T4 } & \multirow[b]{2}{*}{ Médias } \\
\hline & & T2 & T3 & & & & T2 & T3 & & \\
\hline 0 & 217,39 & 234,82 & 224,30 & 230,48 & $226,75^{\text {AD }}$ & 233,47 & 234,52 & 231,62 & 235,02 & $233,65^{A}$ \\
\hline 30 & 239,07 & 231,83 & 224,95 & 230,58 & $231,61^{A}$ & 234,62 & 229,47 & 235,12 & 234,57 & $233,44^{A}$ \\
\hline 60 & 226,45 & 225,68 & 223,55 & 213,01 & $222,17^{b}$ & 230,52 & 233,02 & 234,12 & 234,92 & $233,14^{A}$ \\
\hline 90 & 213,87 & 219,68 & 233,28 & 233,58 & $225,10^{\text {AS }}$ & 225,47 & 236,07 & 231,57 & 234,07 & $231,79^{A}$ \\
\hline 120 & 240,36 & 221,28 & 228,28 & 222,28 & $228,05^{\text {AB }}$ & 226,77 & 232,87 & 235,62 & 233,37 & $232,15^{A}$ \\
\hline 150 & 235,23 & 222,08 & 222,42 & 222,83 & $225,64^{\text {AB }}$ & 232,62 & 234,52 & 234,72 & 233,32 & $233,79^{A}$ \\
\hline 180 & 231,19 & 223,83 & 228,87 & 238,48 & $230,59^{A B}$ & 235,47 & 227,47 & 233,82 & 232,32 & $232,24^{A}$ \\
\hline Médias & $229,08^{A}$ & $225,06^{A}$ & $226,52^{A}$ & $227,32^{\mu}$ & & $231,27^{A}$ & $232,54^{A}$ & $233,79^{A}$ & $233,94^{A}$ & \\
\hline F( Épocas) & $2,75^{*}$ & & & & & $1,24 n . s$ & & & & \\
\hline F( Trat.) & $2,41 \mathrm{n} . \mathrm{s}$ & & & & & 6,60n.s & & & & \\
\hline
\end{tabular}

$\mathrm{T} 1, \mathrm{~T} 2, \mathrm{~T} 3, \mathrm{~T} 4=$ tratamentos de processamento

n.s = não significativo

*= significativa a nível de $5 \%$

As médias seguidas das mesmas letras não diferem entre sí, ao nível de $5 \%$ de probabilidade.

Em relação à medida de vácuo (Tabela 5) não foram observadas variações significativas. Todos valores encontrados estão acima de 10 pol.Hg, o que significa um bom vácuo para os produtos processados.

O oxigênio pode estar na fase gasosa (espaço-livre), dissolvido na fase aquosa ou adsorvido na fase sólida ou semi-sólida. A temperatura de fechamento do recipiente tem grande importância no processo de vácuo (Evangelista, 1992). O vácuo é dependente das operações de exaustão e da temperatura do produto na operação de fechamento dos vidros. A presença de oxigênio tem um efeito muito prejudicial no que diz respeito a reações oxidativas, as quais resultam em deterioração do ácido ascórbico, escurecimento e alterações organolépticas. 
Vários autores evidenciaram a ação negativa do oxigênio na vida útil de geléias ( Fernandes, 1982).

Tabela 5. Vácuo (pol.Hg) das geléias comuns de morango das duas variedades durante arnazenamento.

\begin{tabular}{|c|c|c|c|c|c|c|c|c|c|c|}
\hline \multirow[b]{2}{*}{ Tempo em dias } & \multirow[b]{2}{*}{ T1 } & \multicolumn{2}{|c|}{ Guarani } & \multirow[b]{2}{*}{ T4 } & \multirow[b]{2}{*}{ Médias } & \multicolumn{4}{|c|}{ Oso Grande } & \multirow[b]{2}{*}{ Médias } \\
\hline & & T2 & T3 & & & T1 & T2 & T3 & T4 & \\
\hline 0 & 10,50 & 10,25 & 10,25 & 11,25 & $10,56^{A}$ & 11,00 & 10,75 & 10,50 & 11,25 & $10,87^{A}$ \\
\hline 30 & 10,50 & 10,50 & 11,25 & 11,25 & $10,87^{A}$ & 10,00 & 10,50 & 10,25 & 11,25 & $10,50^{A}$ \\
\hline 60 & 11,00 & 10,25 & 11,00 & 10,00 & $10,56^{A}$ & 10,75 & 11,00 & 11,00 & 10,25 & $10,75^{A}$ \\
\hline 90 & 10,00 & 10,00 & 10,50 & 10,50 & $10,25^{A}$ & 10,50 & 11,25 & 11,25 & 10,25 & $10,81^{A}$ \\
\hline 120 & 10,25 & 10,25 & 10,50 & 10,75 & $10,43^{A}$ & 10,50 & 11,00 & 10,25 & 10,50 & $10,56^{A}$ \\
\hline 150 & 10,25 & 10,25 & 10,25 & 11,25 & $10,50^{A}$ & 11,25 & 10,25 & 10,25 & 10,50 & $10,56^{A}$ \\
\hline 180 & 10,25 & 11,00 & 10,75 & 10,75 & $10,68^{A}$ & 11,00 & 10,50 & 11,00 & 11,50 & $11,00^{A}$ \\
\hline Médias & $10,39^{A}$ & $10,37^{A}$ & $10,64^{A}$ & $10,82^{A}$ & & $10,71^{A}$ & $10,75^{A}$ & $10,64^{A}$ & $10,78^{A}$ & \\
\hline F( Epocas) & 1,57 n.s & & & & & $3,21 n . S$ & & & & \\
\hline $\mathrm{F}$ (Tratamentos) & $1,47 n . s$ & & & & & $0,35 n . s$ & & & & \\
\hline
\end{tabular}

$\mathrm{T} 1, \mathrm{~T} 2, \mathrm{~T} 3, \mathrm{~T} 4=$ tratamentos de processamento n.s = não significativo

As médias seguidas das mesmas letras não diferem entre si, ao nível de $5 \%$ de probabilidade

\subsubsection{Análises químicas}

Os resultados correspondentes as determinações de ácido ascórbico, acidez total titulável, $\mathrm{pH}$ e teores de sólidos solúveis (Brix) das geléias comuns durante 180 dias de armazenamento estão apresentados nas Tabelas 6, 7, 8 e 9.

Como já era esperado, os teores de ácido ascórbico no produto final para as duas variedades foram bem menores que os encontrados nos frutos "in natura" (Tabelas 6 e 2 respectivamente). Segundo Gava (1984), o ácido ascórbico é 
destruído em função do tempo e temperatura de aquecimento. Com aumento da temperatura, ocorre transformação do ácido ascórbico em ácido dehidroascórbico (Eskin,1991).

Tabela 6. Teores de ácido ascórbico (mg / 100g de amostra) das geléias comuns de morango das duas variedades durante amazenamento

\begin{tabular}{|c|c|c|c|c|c|c|c|c|c|c|}
\hline \multirow[b]{2}{*}{$\begin{array}{c}\text { Tempo em } \\
\text { dias }\end{array}$} & \multirow[b]{2}{*}{ T1 } & \multicolumn{2}{|c|}{ Guarani } & \multirow[b]{2}{*}{ T4 } & \multirow[b]{2}{*}{ Médias } & \multirow[b]{2}{*}{ T1 } & \multicolumn{2}{|c|}{ Oso Grande } & \multirow[b]{2}{*}{ T4 } & \multirow[b]{2}{*}{ Médias } \\
\hline & & T2 & T3 & & & & T2 & T3 & & \\
\hline 0 & 35,00 & 37,50 & 35,00 & 50,00 & $39,35^{\mu}$ & 41,25 & 35,00 & 40,00 & 50,00 & $41,56^{A}$ \\
\hline 30 & 35,00 & 35,00 & 35,00 & 47,50 & $38,12^{A}$ & 40,00 & 35,00 & 35,50 & 48,75 & $41,31^{A}$ \\
\hline 60 & 30,00 & 28,75 & 32,50 & 45,00 & $34,06^{B}$ & 37,50 & 35,00 & 35,50 & 45,00 & $37,18^{C}$ \\
\hline 90 & 25,00 & 25,00 & 30,00 & 42,50 & $30,62^{c}$ & 35,00 & 33,75 & 30,00 & 43,75 & $35,31^{8 c i}$ \\
\hline 120 & 27,50 & 25,00 & 27,50 & 40,00 & $30,00^{c}$ & 32,50 & 30,00 & 30,00 & 42,50 & $33,12^{\mathrm{CU}}$ \\
\hline 150 & 25,00 & 25,00 & 25,00 & 40,00 & $28,75^{C}$ & 30,00 & 32,50 & 30,00 & 40,00 & $31,25^{\nu}$ \\
\hline 180 & 25,00 & 22,50 & 25,00 & 38,75 & $27,81^{c}$ & 25,00 & 25,00 & 25,00 & 35,00 & $27,50^{t}$ \\
\hline Médias & $28,92^{\mathrm{B}}$ & $28,39^{\mathrm{B}}$ & $30,00^{\mathrm{B}}$ & $43,39^{A}$ & & $34,46^{C}$ & $30,17^{\mathrm{B}}$ & $32,50 C^{B C}$ & $43,57^{A}$ & \\
\hline F( Epocas) & $50,54^{* *}$ & & & & & $55,92^{\star \star}$ & & & & \\
\hline$F$ (Trat.) & $333,85^{\star *}$ & & & & & $134^{\star *}$ & .. & & & \\
\hline
\end{tabular}

$\mathrm{T} 1, \mathrm{~T} 2, \mathrm{~T} 3, \mathrm{~T} 4=$ tratamentos de processamento

$* *$ = significativo a nível de $1 \%$

As médias seguidas das mesmas letras não diferem entre si, ao nível de $5 \%$ de probabilidade

Para as duas variedades (Tabela 6), o tratamento 4 diferiu dos demais tratamentos apresentando o maior teor de ácido ascórbico, uma vez que este foi enriquecido com a adição desta vitamina. Para a variedade Guarani apenas o tratamento 4 diferiu significativamente dos demais tratamentos; para a variedade Oso Grande o tratamento 1 diferiu dos tratamentos 2 e 4 . Em relação as épocas de avaliação observa-se para as duas variedades que as maiores perdas de ácido ascórbico ocorreram a partir de dois meses de armazenamento. 
Durante os 180 dias de armazenamento o teor de ácido ascórbico sofreu uma redução de $28 \%$ para a variedade Guarani e de $39 \%$ para a variedade Oso Grande. Comparando-se estes resultados com os obtidos por Viberg et al. (1997) em experimentos com geléias de amoras pretas (com perdas de 60\%), conclui-se que os resultados obtidos nesta pesquisa foram bem superiores.

Os tratamentos que são aplicados aos alimentos durante o preparo e processamento podem causar uma série de modificações em sua composição, reduzindo muitas vezes drasticamente o teor de ácido ascórbico. As principais causas da perda desta vitamina estão ligadas as suas características, por se tratar de uma vitamina termolábel e hidrosoluvel (Cid et al., 1990). Segundo Cardelo et al. (1993/94), o ácido ascórbico é um importante indicador de qualidade pois, sendo uma vitamina termolábel sua presença no alimento, após o processamento, indica que provavelmente os demais nutrientes estão preservados.

Os teores de ácido ascórbico obtidos (Tabela 6) são em geral superiores aos obtidos por Kimura et al. (1994) que após o processamento de geléias de morango encontraram valores entre 30 e $20 \mathrm{mg} / 100 \mathrm{~g}$; Charlampowicz \& Wozniak (1969) que encontraram valores de 11 a $14 \mathrm{mg} / 100 \mathrm{~g}$ dependendo da variedade; Diaz-Marquina et al. (1987) os quais analisaram marcas comerciais de geléias e encontraram em média $30,51 \mathrm{mg} / 100 \mathrm{~g}$. Em relação às variedades pode-se observar pelas Fíguras 8 e 9, que a Oso Grande apresentou teores de ácido ascórbico superiores à Guarani, porém em 180 dias de armazenamento as geléias preparadas com as duas variedades apresentam teores semelhantes de ácido ascórbico (Fígura 10). 


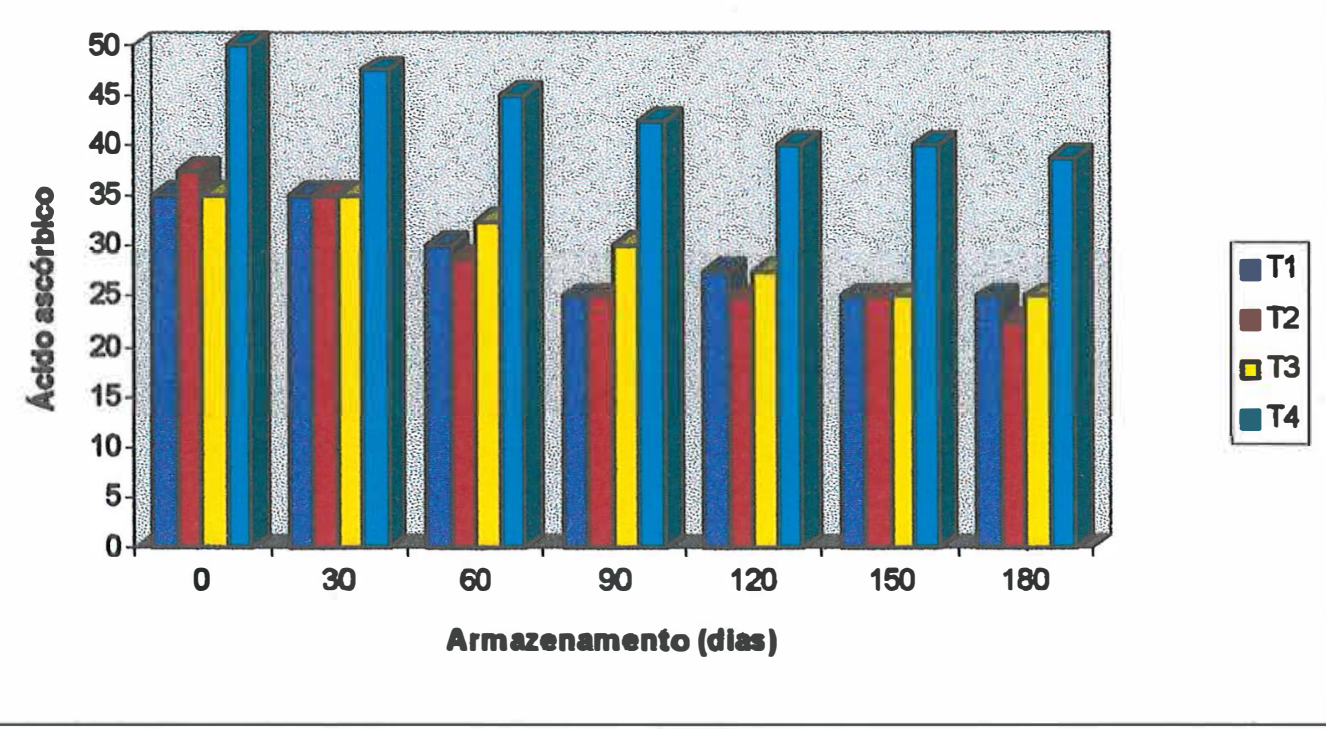

Figura 8. Variação dos teores de ácido ascórbico (mg/100g amostra) das geléias comuns de acordo com os períodos de armazenamento- Variedade Guarani.

Com relação a acidez total titulável (Tabela 7), para a variedade Guarani apenas o tratamento 1 diferiu dos demais tratamentos; para a variedade Oso Grande os tratamentos 1 e 3 diferiram dos tratamentos 2 e 4 . Quanto ao período de armazenamento a variedade Guarani apresentou maiores variações a partir de 120 dias (Figura 12); já para a variedade Oso Grande variações na acidez ocorreram após 30 dias de armazenamento (Figura 13). Observa-se pela Figura 11, que as geléias obtidas com as duas variedades em estudo tem teores de acidez total titulável semelhantes, sendo que para as duas variedades a acidez diminuiu gradativamente durante os 180 dias de armazenamento. Esta queda nos teores de acidez total titulável pode ser justificada com a diminuição dos teores de ácido ascórbico, já que este é um dos ácidos presentes na determinação da acidez total titulável. Os teores de acidez total titulável encontrados mostraram-se inferiores aos obtidos por Costell et al. (1987) e Kamneva \& Lisakova (1973). 


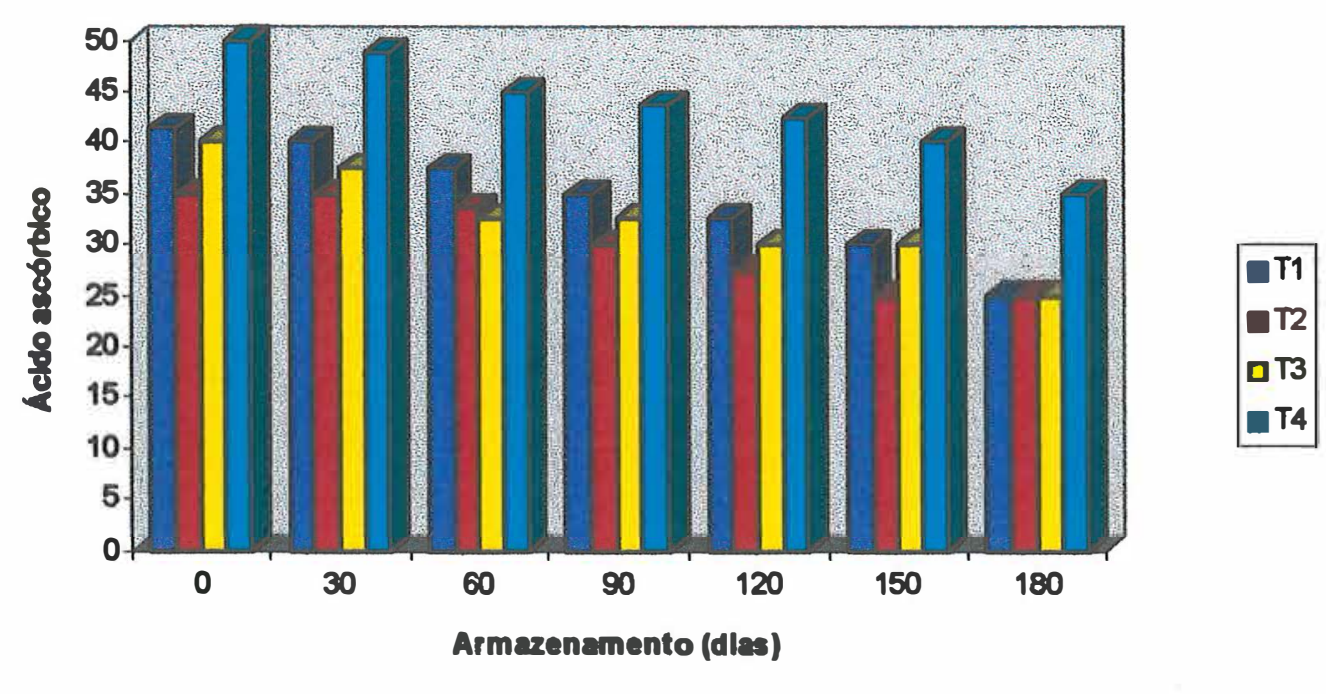

Figura 9. Variação dos teores de ácido ascórbico $(\mathrm{mg} / 100 \mathrm{~g}$ amostra) das geléias comuns de acordo com os períodos de armazenamento- Variedade Oso Grande.

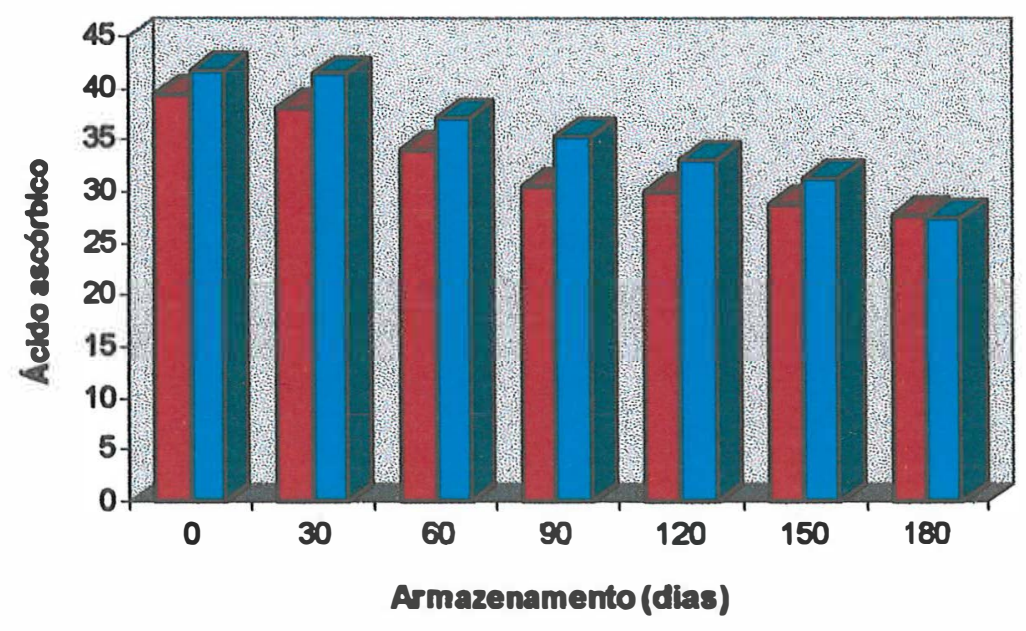

Guarani

Oso Grande

Figura 10. Comparação entre as geléias de morango comuns de morango das duas variedades com relação ao teor de ácido ascórbico (mg/100g amostra) durante armazenamento. 
Tabela 7. Teores de acidez total titulável (g ácido cítrico/100g amostra) das geléias comuns de morango das duas variedades durante armazenamento.

\begin{tabular}{|c|c|c|c|c|c|c|c|c|c|c|}
\hline \multirow[b]{2}{*}{$\begin{array}{c}\text { Tempo em } \\
\text { dias }\end{array}$} & \multicolumn{4}{|c|}{ Guaran! } & \multirow[b]{2}{*}{ Médias } & \multicolumn{4}{|c|}{ Oso Grande } & \multirow[b]{2}{*}{ Médias } \\
\hline & T1 & T2 & T3 & T4 & & $\mathrm{T} 1$ & T2 & T3 & T4 & \\
\hline 0 & 0,33 & 0,38 & 0,37 & 0,36 & $0,36^{\bar{A}}$ & 0,33 & 0,38 & 0,38 & 0,36 & $0,36^{A}$ \\
\hline 30 & 0,29 & 0,36 & 0,37 & 0,36 & $0,34^{A B}$ & 0,29 & 0,36 & 0,37 & 0,36 & $0,35^{B}$ \\
\hline 60 & 0,28 & 0,36 & 0,37 & 0,36 & $0,34^{\text {AB }}$ & 0,28 & 0,36 & 0,32 & 0,36 & $0,33^{C}$ \\
\hline 90 & 0,26 & 0,36 & 0,37 & 0,34 & $0,33^{A B}$ & 0,26 & 0,36 & 0,32 & 0,36 & $0,32^{c}$ \\
\hline 120 & 0,25 & 0,30 & 0,38 & 0,33 & $0,31^{\forall C i}$ & 0,25 & 0,33 & 0,32 & 0,36 & $0,31^{u}$ \\
\hline 150 & 0,25 & 0,30 & 0,36 & 0,33 & $0,31^{B C}$ & 0,25 & 0,32 & 0,31 & 0,35 & $0,31^{\text {vt }}$ \\
\hline 180 & 0,25 & 0,22 & 0,35 & 0,33 & $0,29^{C}$ & 0,25 & 0,32 & 0,30 & 0,34 & $0,28^{t}$ \\
\hline Médias & $0,26^{n}$ & $0,33^{8}$ & $0,36^{B}$ & $0,34^{8}$ & & $0,27^{\circ}$ & $0,35^{n}$ & $0,33^{\circ}$ & $0,35^{x}$ & \\
\hline F (Épocas) & & & & & & $109,46^{\text {w }}$ & & & & \\
\hline$F($ Trat.) & & & & & & 245,49 & & & & \\
\hline
\end{tabular}

$\mathrm{T} 1, \mathrm{~T} 2, \mathrm{~T} 3, \mathrm{~T} 4=$ tratamentos de processamento

**= significativo a nível de $1 \% \quad *$ = significativo a nível de $5 \%$

As médias seguidas das mesmas letras não diferem entre si, ao nível de $5 \%$ de probabilidade

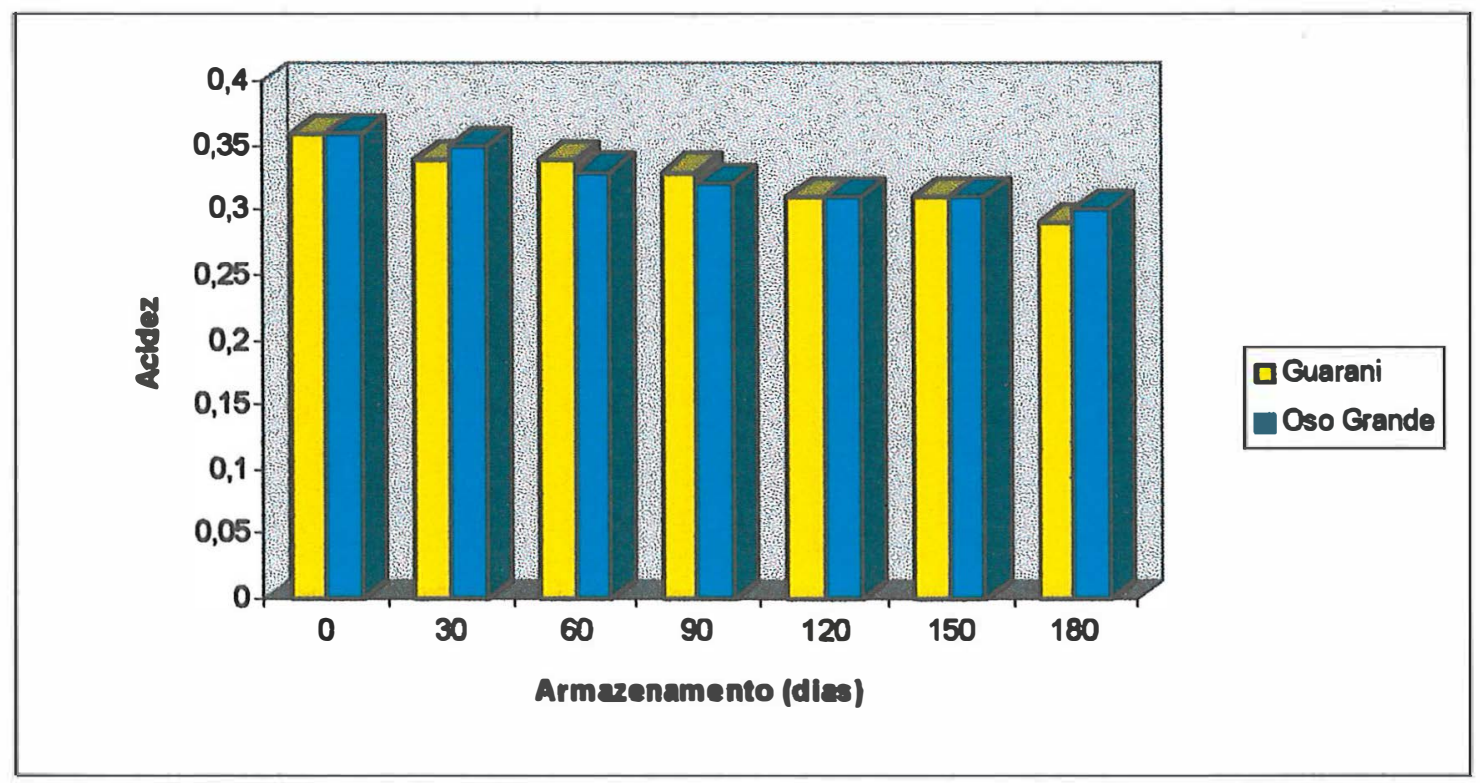

Figura 11. Comparação entre as geléias comuns de morango das duas variedades com relação à acidez total titulável ( $\mathrm{g}$ ácido cítrico/100g amostra) durante armazenamento. 


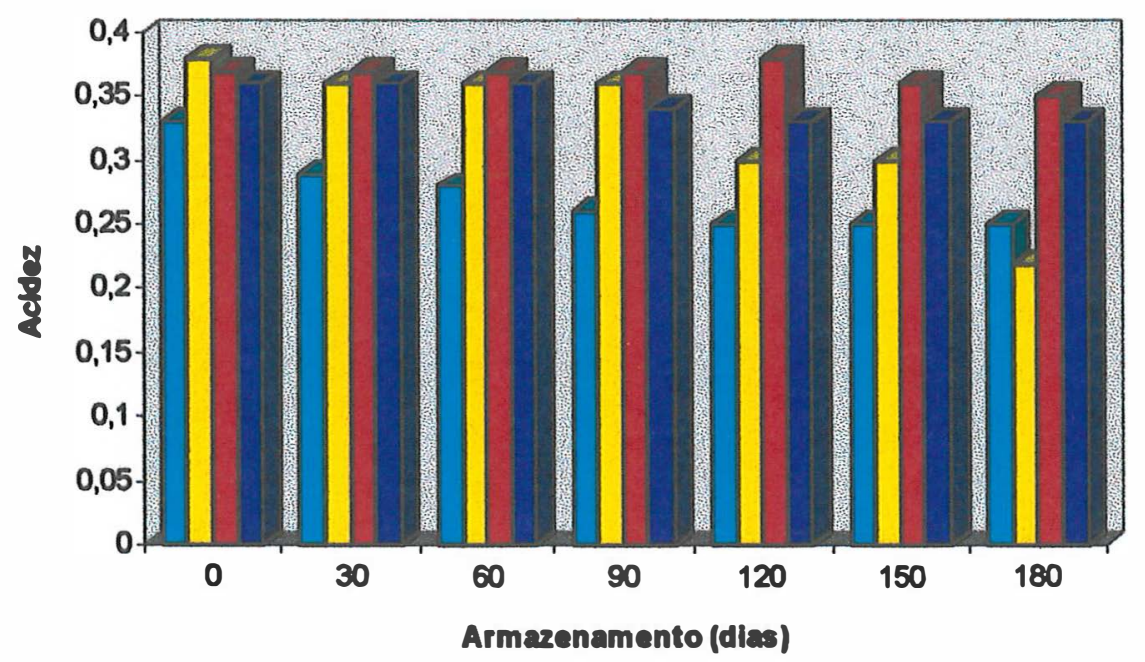

Figura 12. Variação dos teores de acidez total titulável das geléias comuns ( $\mathrm{g}$ ácido cítrico/100g amostra) de acordo com os períodos de armazenamento- Variedade Guarani.

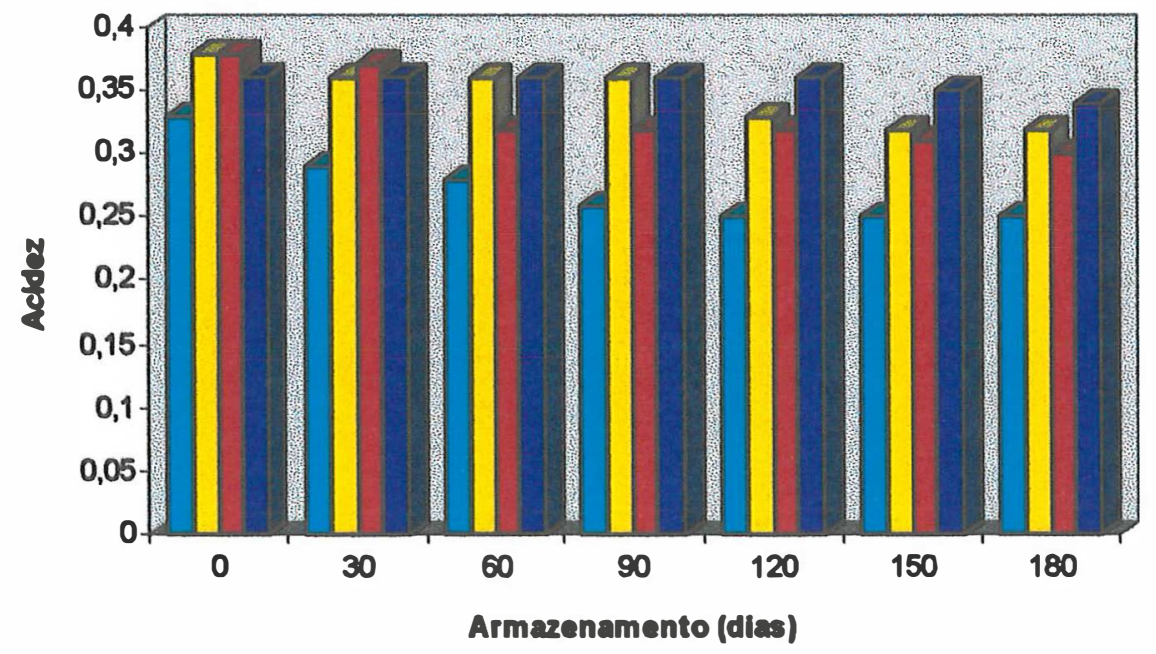

Figura 13. Variação dos teores de acidez total titulável das geléias comuns (g de ácido cítrico/100g amostra) de acordo com os períodos de armazenamento- Variedade Oso Grande. 
Com relação ao pH (Tabela 8), observa-se que para as geléias obtidas com as variedades Guarani e Oso Grande, o tratamento 1 diferiu dos demais tratamentos. $O$ tratamento 1 , ou seja, o tratamento controle ( polpa de morango + açúcar + pectina), apresentou um gel satisfatório apesar do elevado valor de $\mathrm{pH}$ que foi em média 3,54 para a variedade Guarani e 3,71 para a variedade Oso Grande.

Em geral os resultados obtidos são semelhantes aos obtidos por Costell et al. (1987) que estudaram o $\mathrm{pH}$ de várias amostras de geléias de morango e encontraram valores entre 3,27 e 3,52 e aos obtidos por Carbonell et al. (1991) que encontraram valores ao redor de 3,3 .

Tabela 8. Valores de $\mathrm{pH}$ das geléias comuns de morango das duas variedades durante armazenamento.

\begin{tabular}{|c|c|c|c|c|c|c|c|c|c|c|}
\hline \multicolumn{5}{|c|}{ Guarani } & \multirow[b]{2}{*}{ Médias } & \multicolumn{4}{|c|}{ Oso Grande } & \multirow[b]{2}{*}{ Médias } \\
\hline $\begin{array}{l}\text { Tempo em } \\
\text { dias }\end{array}$ & T1 & T2 & T3 & T4 & & T1 & T2 & T3 & T4 & \\
\hline 0 & 3,70 & 3,36 & 3,36 & 3,31 & $3,43^{A}$ & 3,82 & 3,36 & 3,33 & 3,32 & $3,46^{A}$ \\
\hline 30 & 3,69 & 3,33 & 3,34 & 3,32 & $3,42^{A}$ & 3,80 & 3,36 & 3,31 & 3,31 & $3,44^{A}$ \\
\hline 60 & 3,67 & 3,33 & 3,30 & 3,40 & $3,42^{A}$ & 3,78 & 3,35 & 3,30 & 3,30 & $3,43^{A}$ \\
\hline 90 & 3,61 & 3,29 & 3,28 & 3,28 & $3,37^{b}$ & 3,75 & 3,33 & 3,28 & 3,30 & $3,41^{A}$ \\
\hline 120 & 3,43 & 3,24 & 3,27 & 3,22 & $3,29^{c}$ & 3,63 & 3,21 & 3,26 & 3,26 & $3,34^{A}$ \\
\hline 150 & 3,44 & 3,22 & 3,20 & 3,16 & $3,25^{\mathrm{V}}$ & 3,60 & 3,16 & 3,21 & 3,21 & $3,30^{\mathrm{BC}}$ \\
\hline 180 & 3,26 & 3,06 & 3,20 & 3,11 & $3,16^{t}$ & 3,60 & 3,15 & 3,21 & 3,20 & $3,29^{c}$ \\
\hline Médias & $3,54^{A}$ & $3,26^{B}$ & $3,28^{B}$ & $3,26^{B}$ & & $3,71^{A}$ & $3,27^{B}$ & $3,27^{B}$ & $3,27^{B}$ & - \\
\hline $\bar{F}$ (Épocas) & $186,57^{\star \star}$ & & & & & $40,93^{\star \star}$ & & & & \\
\hline F(Tratamentos) & $122,44^{\star \star}$ & & & & & $14966^{\star \star}$ & & & & \\
\hline
\end{tabular}

$\mathrm{T} 1, \mathrm{~T} 2, \mathrm{~T} 3, \mathrm{~T} 4=$ tratamentos de processamento

$* *=$ significativo a nível $1 \%$

As médias seguidas das mesmas letras não diferem entre si, ao nível de $5 \%$ de probabilidade 
Segundo Evangelista (1991), para a formação correta do gel deve existir um equilíbrio entre a concentração de pectina (0,5 a 1,5\%), quantidade de açúcar (Brix entre 64 a 71\%) e com pH na faixa de 3,0 a 3,4.

Comparando-se as duas variedades observa-se pela Figura 14, que as geléias obtidas com a variedade Oso Grande apresentaram valores de $\mathrm{pH}$ superiores em relação à variedade Guarani. Com relação ao tempo de armazenamento houve queda do $\mathrm{pH}$ das geléias durante os 180 dias de armazenamento. Para a variedade Guarani, as maiores variações ocorreram a partir de 90 dias de armazenamento e para a variedade Oso Grande a partir em 120 dias de armazenamento (Figuras 15 e 16). Esta diminuição significativa dos valores de $\mathrm{pH}$ pode ser justificada pela dissociação dos ácidos. Segundo Moore (1976), com a temperatura e tempo de estocagem ocorre dissociação dos ácidos, aumentando o número de ions hidrogênio, conseqüentemente diminuindo o $\mathrm{pH}$.

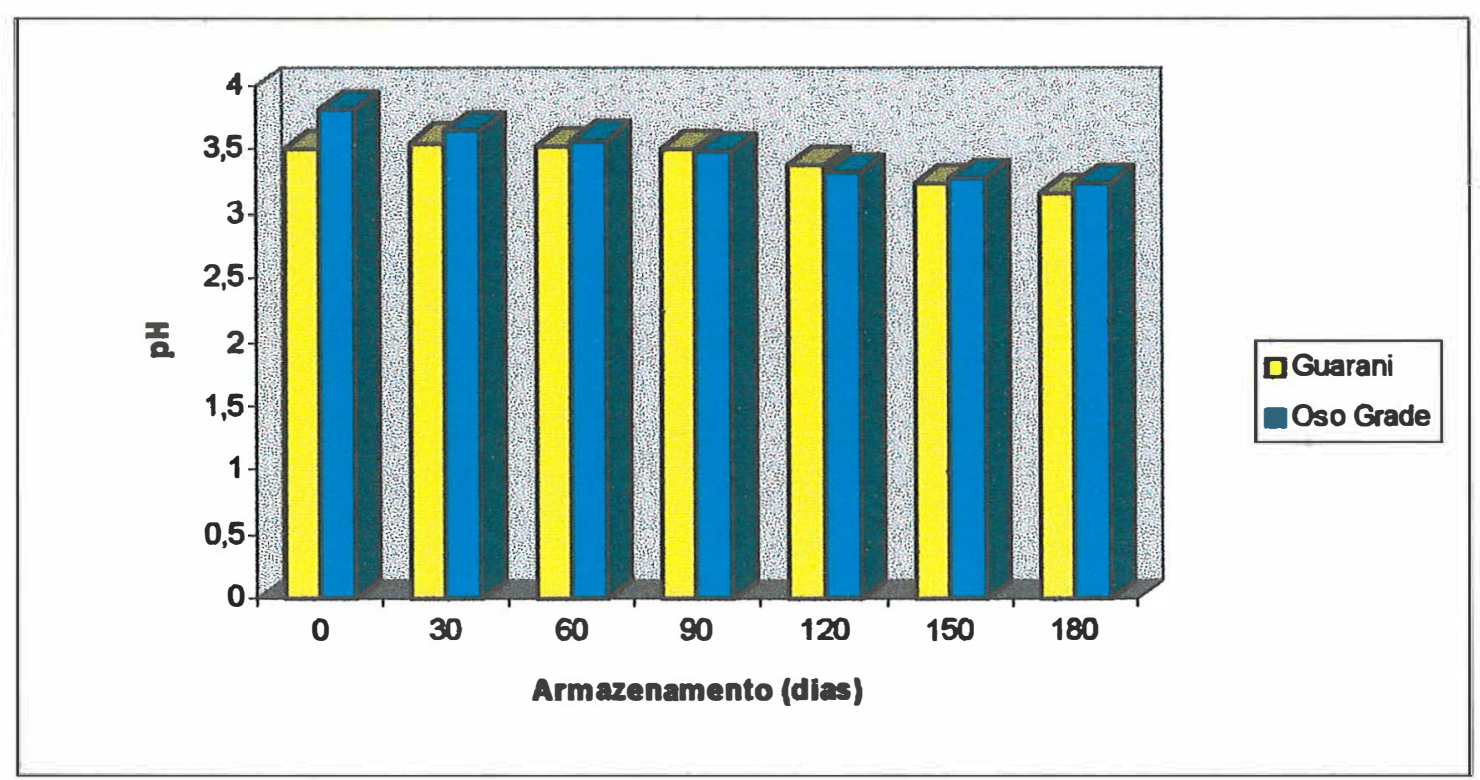

Figura 14. Comparação entre as geléias comuns de morango das duas variedades em relação ao $\mathrm{pH}$ durante armazenamento. 


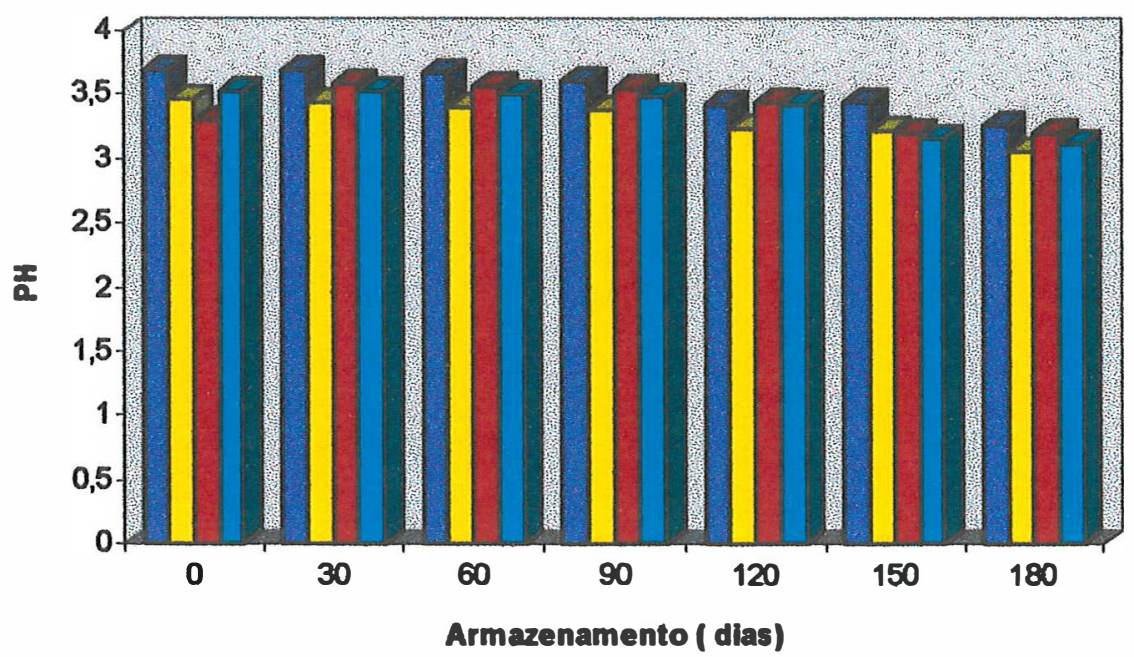

Figura 15. Variação dos valores de $\mathrm{pH}$ das geléias comuns de acordo com os períodos de armazenamento- Variedade Guarani.

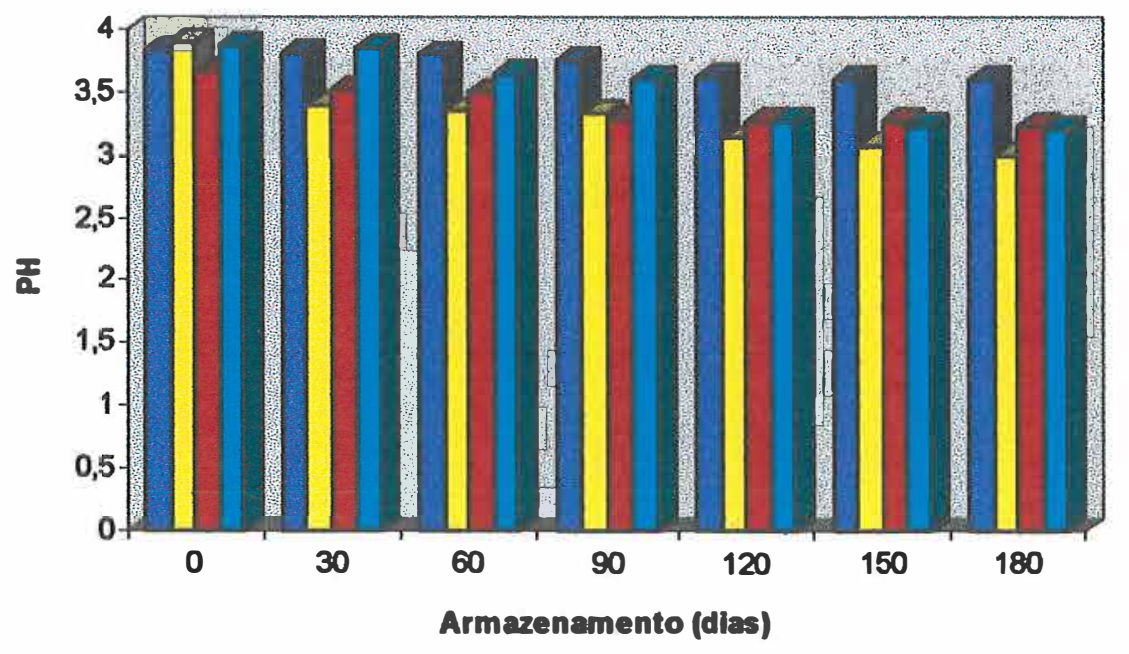

Figura 16. Variação dos valores de $\mathrm{pH}$ das geléias comuns de acordo com os períodos de armazenamento- Variedade Oso Grande. 
Quanto ao teor de sólidos solúveis (Tabela 9), os resultados mostraram que para ambas variedades todos os tratamentos diferiram entre si. Durante o armazenamento ocorreram variações significativas para as geléias obtidas com as duas variedades em estudo. Para a variedade Guarani, as maiores variações ocorreram a partir do segundo mês de armazenamento (Figura 18) e para a variedade Oso Grande a partir do primeiro mês de armazenamento ( Figura 19).

As geléias elaboradas com as variedades Guarani apresentaram valores médios de sólidos solúveis superiores à variedade Oso Grande (Figura 17), com uma diferença inicial de $4^{\circ}$ Brix.

Tabela 9. Teores de sólidos solúveis (Brix) das geléias comuns de morango das duas variedades durante armazenamento.

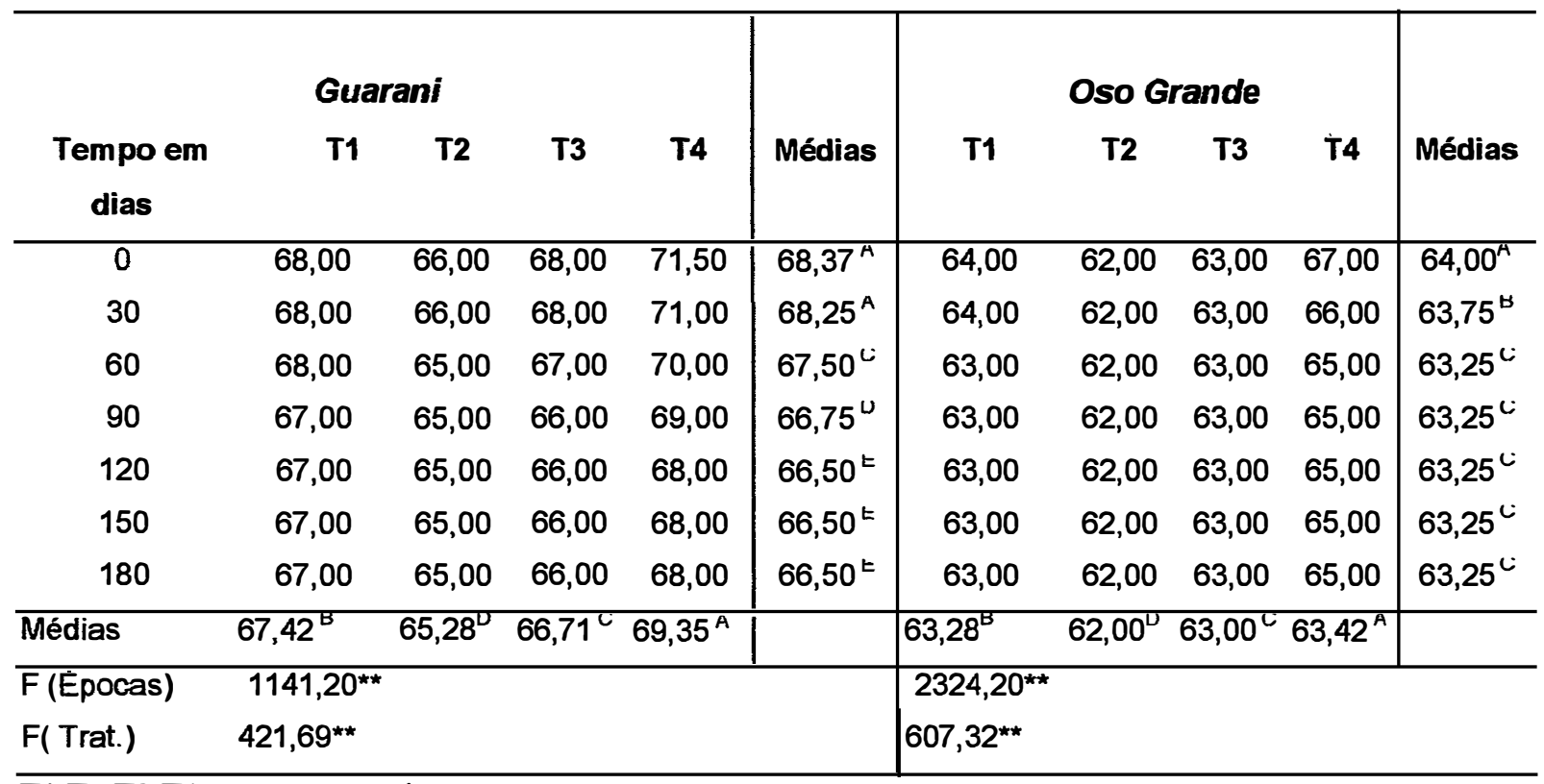

$\mathrm{T} 1, \mathrm{~T} 2, \mathrm{~T} 3, \mathrm{~T} 4=$ tratamentos de processamento ** = significativo a nível de $1 \%$

As médias seguidas das mesmas letras não diferem entre si, ao nível de $5 \%$ de probabilidade 
Os teores de sólidos solúveis obtidos são concordantes com Carbonell et al. (1991) que encontraram valores entre 62,3 e 70,2\% e Costell et al. (1987) que encontraram valores entre 61,8 e $70,3 \%$.

A geléia hermeticamente fechada, tendo características de baixo $\mathrm{pH}$ e elevado Brix, praticamente não propicia risco de desenvolvimento de microrganismos (Gava,1989).

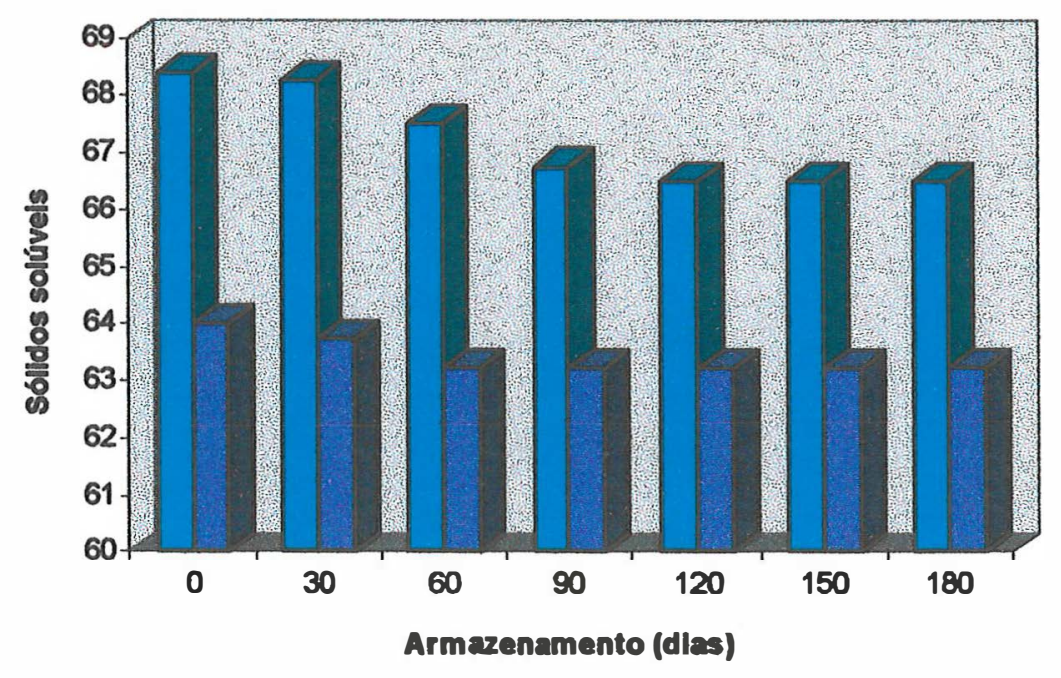

Guarani

Oso Grande

Figura 17. Comparação entre as geléias comuns de morango das duas variedades com relação aos teores de sólidos solúveis (Brix) durante armazenamento. 


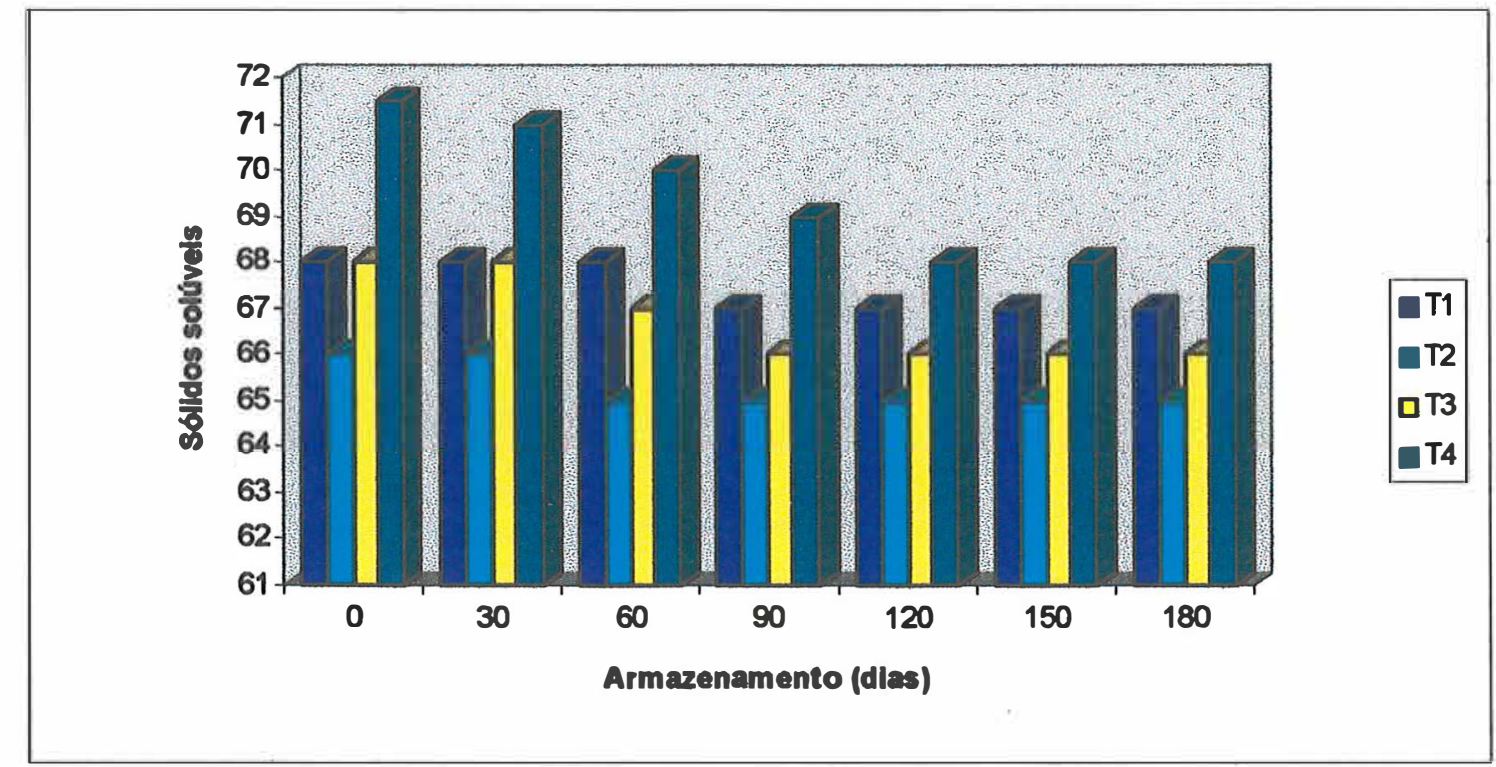

Figura 18. Variação dos teores de sólidos solúveis (Brix) das geléias comuns de acordo com os períodos de armazenamento- Variedade Guarani.

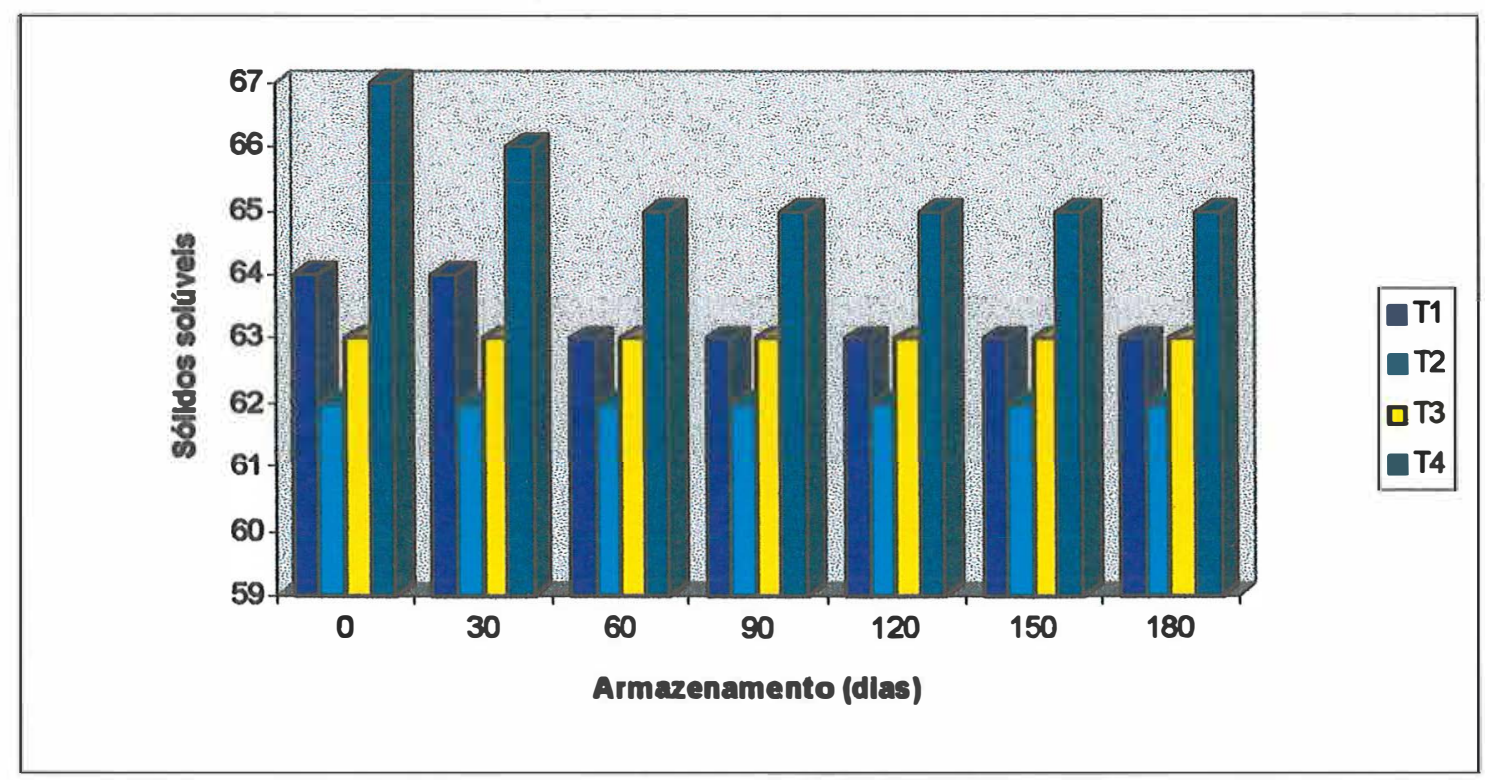

Figura 19. Variação dos teores de sólidos solúveis (Brix) das geléias comuns de acordo com os períodos de armazenamento- Variedade Oso Grande. 


\subsubsection{Análises sensoriais}

Os resultados da avaliação subjetiva do sabor, cor e textura das geléias comuns durante três meses de armazenamento ( 30,60 e 90 dias) são apresentados nas Tabelas 10, 11, 12, 13, 14 e 15 .

Aos trinta dias de armazenamento, apenas o tratamento 1 (polpa de morango + açúcar + pectina) diferiu significativamente quanto ao sabor dos outros tratamentos para as geléias obtidas com as duas variedades em estudo, sendo este considerado pelos provadores como o pior tratamento (Tabela 10). Para as geléias obtidas com a variedade Guarani (Figura 20) os tratamentos 2 (polpa de morango + sacarose + pectina + ácido cítrico ) e 3 (polpa de morango + sacarose + pectina + ácido cítrico + sorbato de potássio) foram os preferidos pelos provadores obtendo as maiores médias para este atributo $(8,12)$; para a variedade Oso Grande (Figura 21) os tratamentos 2, 3 e 4 (polpa de morango + sacarose + pectina + ácido cítrico + sorbato de potássio + cloreto de estanho + ácido ascórbico) foram os preferidos pelos provadores, obtendo a melhor avaliação para este atributo $(8,50)$.

Tabela 10. Avaliação sensorial do sabor das geléias comuns de morango das duas variedades durante armazenamento.

\begin{tabular}{|c|c|c|c|c|c|c|}
\hline \multirow{3}{*}{ Tratamentos } & \multicolumn{2}{|c|}{ MÉDIAS } & \multicolumn{2}{|c|}{ DAS ANA LISES } & \multirow{2}{*}{\multicolumn{2}{|c|}{90 DIAS }} \\
\hline & \multicolumn{2}{|c|}{30 DIAS } & \multicolumn{2}{|c|}{60 DIAS } & & \\
\hline & Guarani & Oso Grande & Guarani & Oso Grande & Guarani & Oso Grande \\
\hline 1 & $6,87^{B}$ & $6,75^{\mathrm{B}}$ & $7,25^{B}$ & $6,50^{\mathrm{B}}$ & $6,75^{\mathrm{B}}$ & $6,12^{B}$ \\
\hline 2 & $8,12^{\mathrm{A}}$ & $8,25^{\mathrm{A}}$ & $7,75^{\mathrm{AB}}$ & $8,00^{\mathrm{A}}$ & $6,75^{\mathrm{B}}$ & $8,12^{\mathrm{A}}$ \\
\hline 3 & $8,12^{A}$ & $8,37^{A}$ & $8,37^{A}$ & $8,12^{A}$ & $7,75^{\mathrm{A}}$ & $8,12^{\mathrm{A}}$ \\
\hline 4 & $7,75^{\mathrm{A}}$ & $8,50^{\mathrm{A}}$ & $7,12^{\mathrm{B}}$ & $8,25^{\mathrm{A}}$ & $6,62^{\mathrm{B}}$ & $8,12^{\mathrm{A}}$ \\
\hline F (trat.) & $7,89 * *$ & $18,30^{* *}$ & $5,29 *$ & $5,73^{*}$ & $6,93 * *$ & $17,68^{* *}$ \\
\hline $\mathrm{F}$ (provad.) & $1,91 *$ & $0,35 n . s$ & $2,20 *$ & $0,28 \mathrm{n} . \mathrm{s}$ & $1,68 \mathrm{n} . \mathrm{s}$ & $3,16^{*}$ \\
\hline
\end{tabular}

n.s-nãosignificativo

* significativo a nível de $5 \%$ **- significativo a nível de $1 \%$

As médias seguidas das mesmas letras não diferem entre si, ao nível de $5 \%$ de probabilidade. 


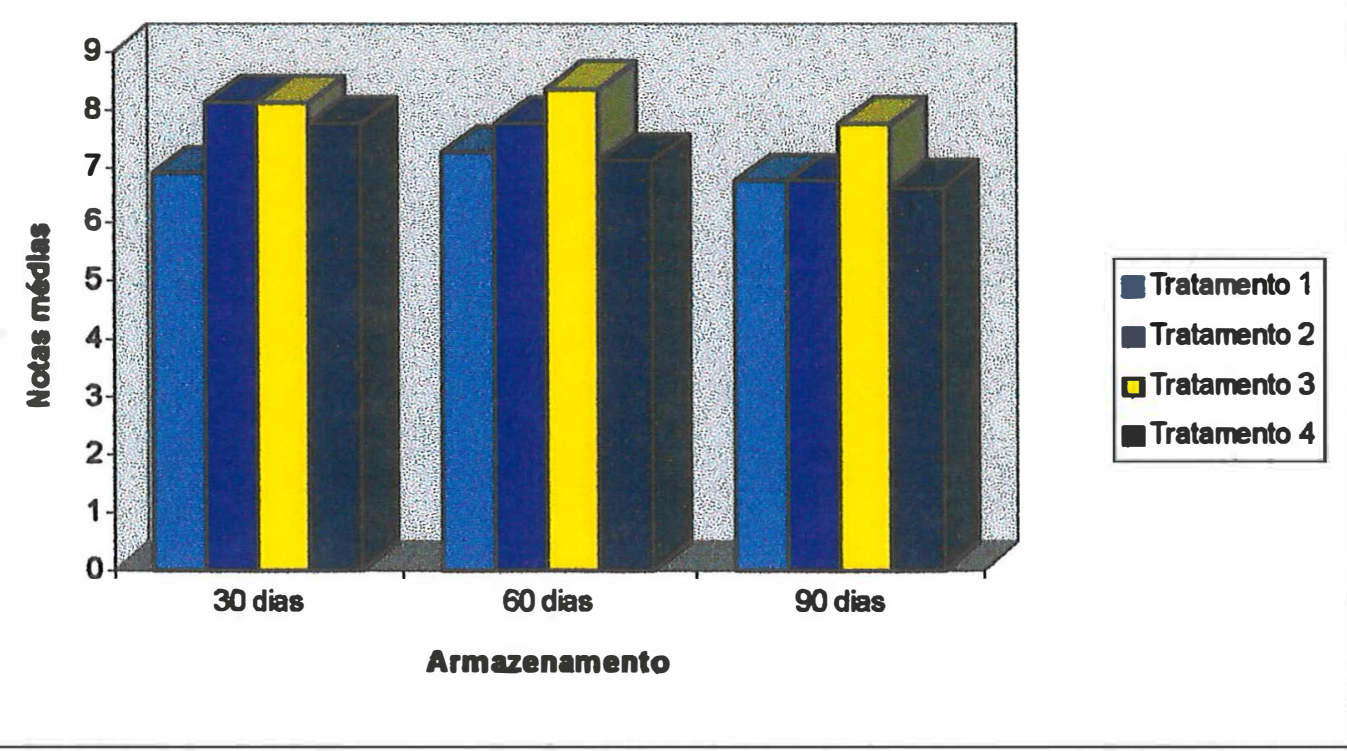

Figura 20. Valores médios obtidos na avaliação sensorial das geléias comuns quanto ao sabor durante armazenamento- Variedade Guarani.

Para a variedade Guarani aos sessenta dias de armazenamento os tratamentos 1 e 4 não diferiram entre si, porém ambos diferem do tratamento 3; para a variedade Oso Grande o tratamento 1 diferiu dos demais tratamentos (Tabela 10). De um modo geral o tratamento considerado pelos provadores como o melhor sabor foi o tratamento 3 (polpa de morango + sacarose + pectina + ácido cítrico + sorbato de potássio + cloreto de estanho), para a variedade Guarani (Figura 20 ) e os tratamentos 2, 3 e 4 (polpa de morango + sacarose + pectina + ácido cítrico + sorbato de potássio + cloreto de estanho + ácido ascórbico) para a variedade Oso Grande ( Figura 21). 


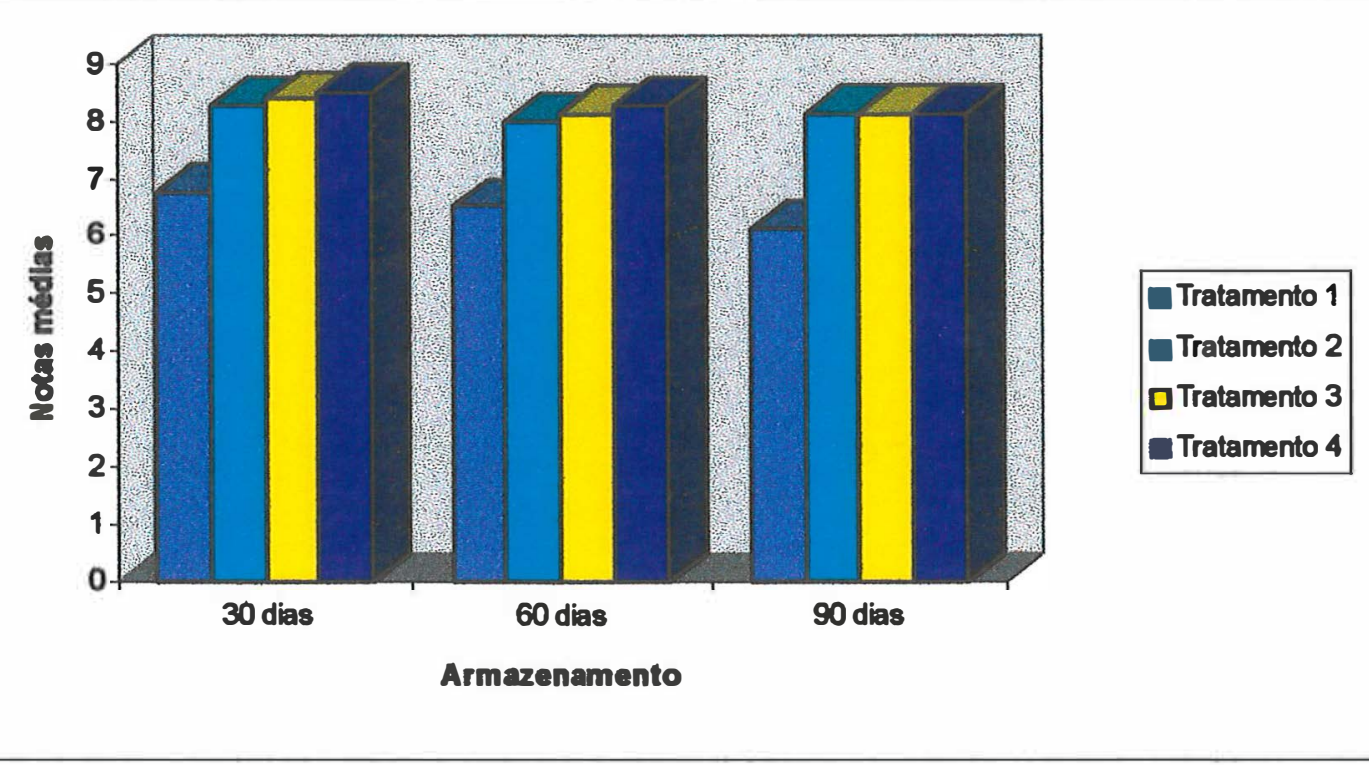

Figura 21. Valores médios obtidos na avaliação sensorial das geléias comuns quanto ao atributo sabor durante armazenamento- Variedade Oso Grande.

Aos noventa dias de armazenamento (Tabela 10), para a variedade Guarani, o tratamento 3 diferiu dos demais tratamentos e também foi o preferido pelos provadores, obtendo a maior média para este atributo $(7,75)$, enquanto que para a variedade Oso Grande os tratamentos 2, 3 e 4 não diferiram entre si e foram os preferidos pelos provadores (média 8,12).

Quanto aos periodos de armazenamento, observa-se pela Tabela 11, que ocorreram diferenças estatisticas significativas somente após dois meses de armazenamento, ou seja nos dois primeiros meses de armazenamento as geléias permaneceram estáveis com relação ao sabor. 
Tabela 11. Comparação entre as geléias comuns de morango das duas variedades com relação ao sabor durante armazenamento.

\begin{tabular}{c|cc}
\hline \multirow{2}{*}{$\begin{array}{c}\text { Épocas de avaliação } \\
\text { (dias) }\end{array}$} & \multicolumn{2}{|c}{ Médias das Análises } \\
\cline { 2 - 3 } & Guarani & Oso Grande \\
\hline 30 & $7,71^{\mathrm{A}}$ & $7,99^{\mathrm{A}}$ \\
60 & $7,62^{\mathrm{A}}$ & $7,71^{\mathrm{A}}$ \\
90 & $6,96^{\mathrm{B}}$ & $7,05^{\mathrm{B}}$ \\
\hline Médias & $7,43^{\mathrm{B}}$ & $7,58^{\mathrm{A}}$ \\
F(épocas) & $11,15^{* *}$ & $15,53^{* *}$ \\
\hline
\end{tabular}

- **significativo a nível de $1 \%$

As médias seguidas das mesmas letras não diferem entre si, ao nível de $5 \%$ de probabilidade.

As geléias elaboradas com as duas variedades foram consideradas de sabor "bom" mesmo com 3 meses de armazenamento, sendo que as preparadas com a variedade Oso Grande foram as preferidas pela equipe de provadores (Tabela 11).

Pela Tabela 12 observa-se que, quanto a cor, aos trinta dias de armazenamento para a variedade Guarani os tratamentos 1 e 2 não diferiram entre si, porem ambos diferiram do tratamento 4; para a variedade Oso Grande os tratamentos 1 e 4 não diferiram entre si, mas diferiram dos tratamentos 2 e 3. Neste período, os tratamentos 1 e 2 foram os preferidos para as geléias obtidas com a variedade Guarani e os tratamentos 2 e 3 para as geleías obtidas com a variedade Oso Grande ( Figuras 22 e 23) .

Aos sessenta dias de armazenamento (Tabela 12) não foram observadas diferenças significativas quanto à cor entre os tratamentos para a variedade Guarani; para a variedade Oso Grande os tratamentos 1 e 4 diferiram significativamente dos tratamentos 2 e 3 . Os tratamentos preferidos pelos 
provadores foram todos para a variedade Guarani e o 2 e 3 para a variedade Oso Grande (Figuras 22 e 23 respectivamente).

Tabela 12. Avaliação sensorial da cor das geléias comuns de morango das duas variedades durante armazenamento.

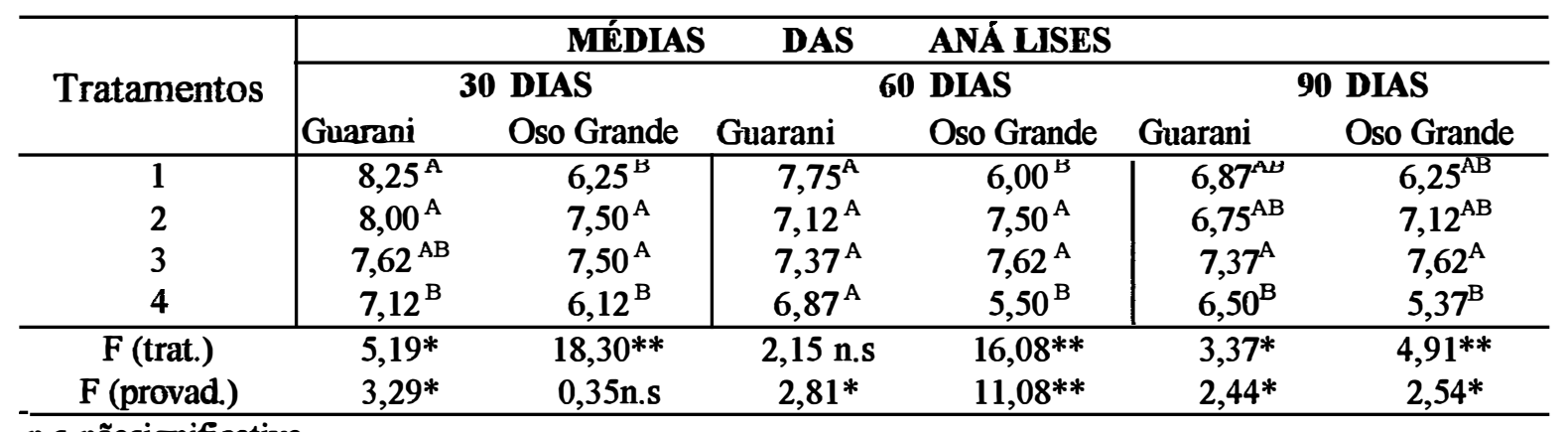

n.s-nãosignificativo

$*$ =significativo a nivel de $5 \%$

**= significativo a nível de $1 \%$

As médias seguidas das mesmas letras não diferem entre si, ao nível de $5 \%$ de probabilidade.

Observa-se pelas Figuras 22 e 23, que as piores notas em relação à cor durante os 90 dias de armazenamento foram recebidas pelo tratamento 4 (polpa de morango + sacarose + pectina + ácido cítrico + sorbato de potássio + cloreto de estanho + ácido ascórbico), para as geléias obtidas com as duas variedades estudadas.

Segundo Chichester (1982), o ácido ascórbico tem efeito negativo na estabilidade da cor de produtos de morango, uma vez que acelera a razão da degradação das antocianinas. Tem sido sugerido a adição de ácido ascórbico para aumentar o valor nutricional de produtos processados, porém como foi constatado a adição desta vitamina prejudicou a cor das geléias. Uma tentativa seria utilizar corantes naturais ou artificiais quando for adicionado ácido ascórbico em geléias de morango. 

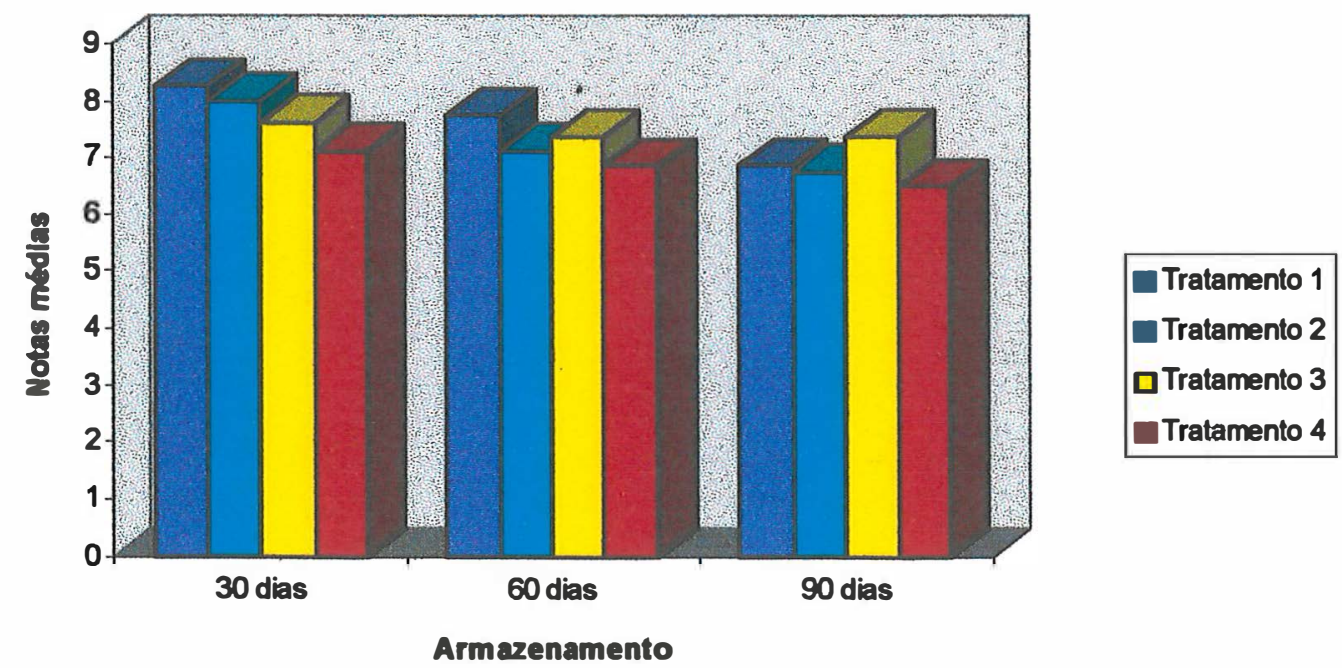

Figura 22. Valores médios obtidos na avaliação sensorial das geléias comuns quanto a cor durante armazenamento- Variedade Guarani.

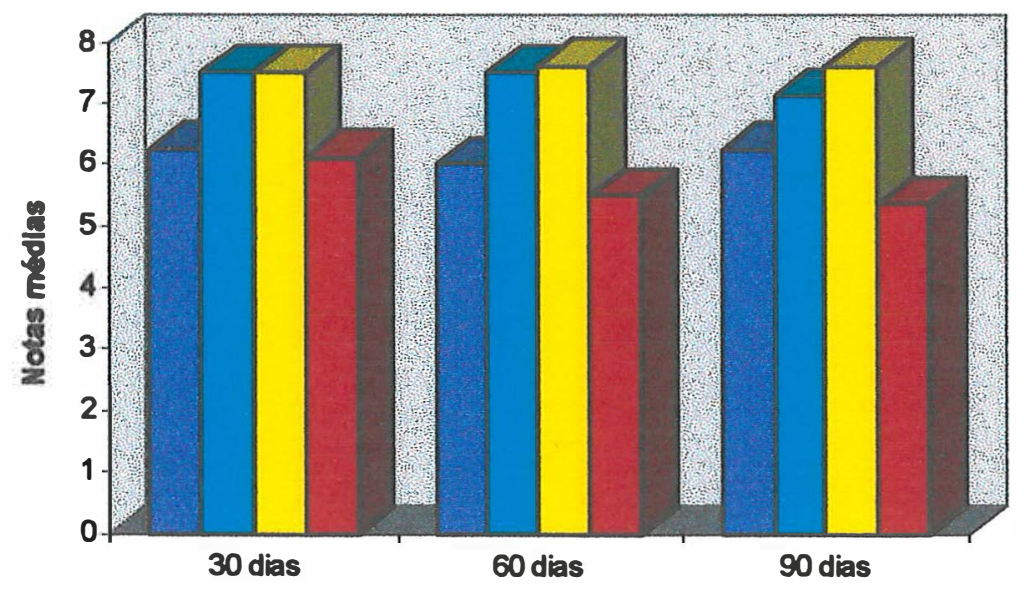

Tratamento 1

Tratamento 2

口Tratamento 3

Tratamento 4

Armazenamento

Figura 23. Valores médios obtidos na avaliação sensorial das geléias comuns quanto a cor durante armazenamento- Variodade Oso Grande. 
Aos noventa dias de armazenamento as melhores avaliações para a cor foram recebidas pelo tratamento 3 ( polpa de morango + sacarose + pectina + ácido cítrico + sorbato de potássio + cloreto de estanho), para as geléias preparadas com as duas variedades, que correspondem a cor classificada como "boa" na escala utilizada (Figuras 22 e 23).

Segundo Sistrunk \& Cash (1970) o uso de cloreto de estanho previne o escurecimento de purês de morango, pois o pigmento cianidina-3monoglucosideo tem dois grupos fenólicos vicinais, que podem ser complexados com íons metálicos. O uso de cloreto de estanho nas geléias comuns preveniu o escurecimento e uma cor vermelho púrpura estável se desenvolveu.

Em relação às épocas de avaliação verifica-se pela Tabela 13, que apenas as geléias elaboradas com a variedade Guarani sofreram mudanças significativas na cor durante o tempo de armazenamento. De maneira geral, os provadores preferiram a cor das geléias elaboradas com a variedade Guarani. Observa-se pelas Figuras 24 e 25 (cortes longitudinais e transversais das variedades Guarani e Oso Grande) que a variedade Guarani possui uma coloração interna vermelha bem mais intensa do que a variedade Oso Grande, portanto as geléias elaboradas com a variedade Guarani apresentaram uma melhor cor.

Segundo Passos (1989), a variedade Guarani apresenta intensa coloração interna, o que seria de interesse na conservação da cor por vários meses em produtos processados, e, também na possibilidade de substituir o uso de corantes. 


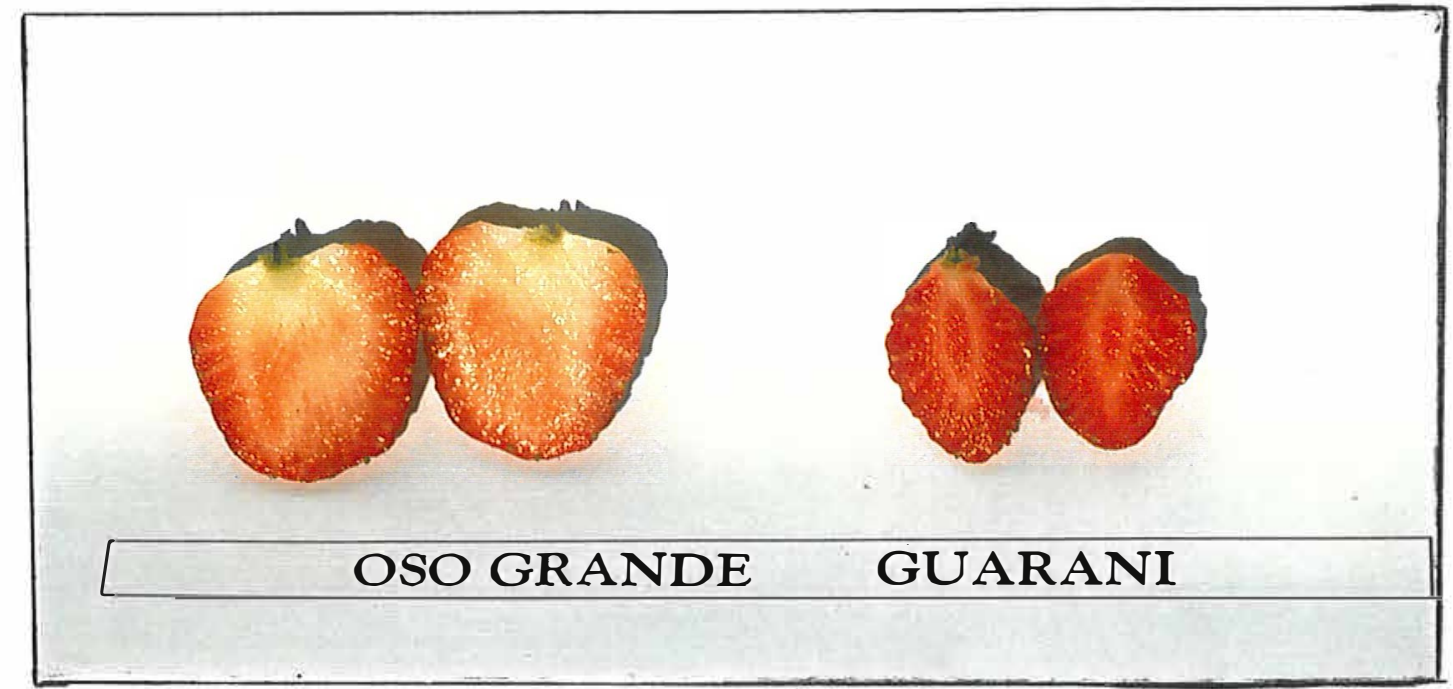

Figura 24. Cortes transversais das variedades Oso Grande e Guarani.

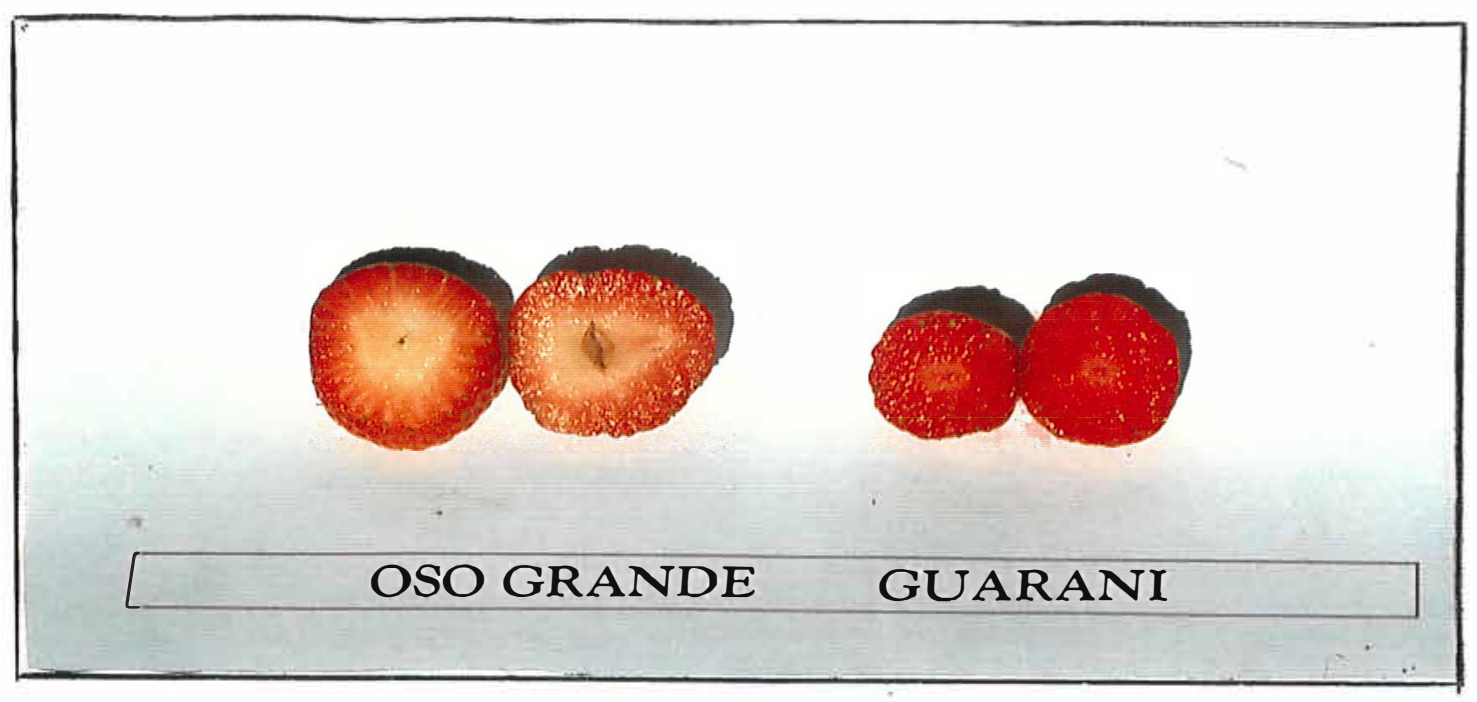

Figura 25. Cortes longitudinais das variedades Oso Grande e Guarani. 
Tabela 13. Comparação entre as geléias comuns de morango das duas variedades com relação a cor durante armazenamento.

\begin{tabular}{c|cc}
\hline \multirow{2}{*}{$\begin{array}{c}\text { Épocas de avaliação } \\
\text { (dias) }\end{array}$} & \multicolumn{2}{|c}{ Média das Análises } \\
\cline { 2 - 3 } & Guarani & Oso Grande \\
\hline 30 & $7,74^{\mathrm{A}}$ & $6,84^{\mathrm{A}}$ \\
60 & $7,27^{\mathrm{AB}}$ & $6,65^{\mathrm{A}}$ \\
90 & $6,87^{\mathrm{B}}$ & $6,59^{\mathrm{A}}$ \\
\hline Médias & $7,29^{\mathrm{A}}$ & $6,69^{\mathrm{B}}$ \\
F(épocas) & $0,40^{* *}$ & $2,1 \ln . \mathrm{s}$ \\
\hline
\end{tabular}

n.s-nãosignificativa

**- significativo a nível de $1 \%$

As médias seguidas das mesmas letras não diferem entre si, ao nível de $5 \%$ de probabilidade.

Quanto à textura verifica-se pela Tabela 14, que para as geléias preparadas com a variedade Guarani não ocorreram diferenças significativas entre os tratamentos durante o armazenamento, porém o tratamento preferido pelos provadores foi o 3 (Figura 26); para as geléias preparadas com a variedade Oso Grande o tratamento 1 diferiu dos demais tratamentos em todas as épocas de avaliação e foi considerado o pior tratamento em relação à textura (Figura 27). Este resultado pode ser explicado já que o $\mathrm{pH}$ do tratamento 1 foi o mais elevado (em média 3,71), o que torna a consistência do gel bem mais fraca.

Durante os 90 dias de armazenamento não ocorreram diferenças significativas na textura das geléias preparadas com as duas variedades em estudo (Tabela 15).

De maneira geral, os provadores aprovaram a textura das geléias em estudo considerando-as "boas", mas preferiram a textura das geléias preparadas com a variedade Oso Grande (Tabela 15). Segundo Sánches (1996), a qualidade 
e aceitabilidade dos alimentos é muito influenciada pelas propriedades de textura dos mesmos.

Tabela 14. Avaliação sensorial da textura das geléias comuns de morango das duas variedades durante armazenamento.

\begin{tabular}{|c|c|c|c|c|c|c|}
\hline \multirow{3}{*}{ Tratamentos } & \multicolumn{2}{|r|}{ MÉDIAS } & \multicolumn{2}{|c|}{$\begin{array}{l}\text { ANÁ LISES } \\
\text { DIAS }\end{array}$} & \multirow{2}{*}{\multicolumn{2}{|c|}{90 DIAS }} \\
\hline & \multicolumn{2}{|c|}{30 DIAS } & \multicolumn{2}{|c|}{60 DIAS } & & \\
\hline & Guarani & Oso Grande & Guarani & Oso Grande & Guarani & Oso Grande \\
\hline 1 & $7,00^{A}$ & $6,37^{B}$ & $7,00^{A}$ & $6,25^{\mathrm{B}}$ & $6,87^{A}$ & $5,37^{\mathrm{B}}$ \\
\hline 2 & $7,12^{\mathrm{A}}$ & $7,62^{A}$ & $7,12^{\mathrm{A}}$ & $7,50^{\mathrm{A}}$ & $7,12^{\mathrm{A}}$ & $7,37^{\mathrm{A}}$ \\
\hline 3 & $7,25^{\mathrm{A}}$ & $7,75^{\mathrm{A}}$ & $7,50^{\mathrm{A}}$ & $8,25^{\mathrm{A}}$ & $7,12^{\mathrm{A}}$ & $7,25^{\mathrm{A}}$ \\
\hline 4 & $7,12^{\mathrm{A}}$ & $8,12^{A}$ & $7,12^{A}$ & $8,12^{A}$ & $7,12^{\mathrm{A}}$ & $8,00^{A}$ \\
\hline$F$ (trat.) & 0,47 & 10,30 & 1,24 n.s & $9,94^{*}$ & $1,00 \mathrm{n} . \mathrm{s}$ & $8,20 * *$ \\
\hline F (provad.) & 9,20 & 1,50 & $0,65 \mathrm{n} . \mathrm{s}$ & 0,79 n.s & $1,00 \mathrm{n} . \mathrm{s}$ & $5,60 * *$ \\
\hline
\end{tabular}

n.s-nãosignificativo

*= significativo a nível de $5 \%$

$* *=$ significativo a nível de $1 \%$

As médias seguidas das mesmas letras não diferem entre si, ao nível de $5 \%$ de probabilidade.

Tabela 15. Comparação entre as geléias comuns de morango das duas variedades com relação a textura durante armazenamento.

\begin{tabular}{c|cc}
\hline \multirow{2}{*}{$\begin{array}{c}\text { Epocas de avaliação } \\
\text { (dias) }\end{array}$} & \multicolumn{2}{|c}{ Média das Análises } \\
\cline { 2 - 3 } & Guarani & Oso Grande \\
\hline 30 & $7,12^{\mathrm{A}}$ & $7,46^{\mathrm{A}}$ \\
60 & $7,18^{\mathrm{A}}$ & $7,53^{\mathrm{A}}$ \\
90 & $7,05^{\mathrm{A}}$ & $6,99^{\mathrm{A}}$ \\
\hline Médias & $7,12^{\mathrm{A}}$ & $7,33^{\mathrm{A}}$ \\
F(épocas) & $0,40 \mathrm{n} . \mathrm{s}$ & $2,11 \mathrm{n} . \mathrm{s}$ \\
\hline
\end{tabular}

n.s=não significativo

As médias seguidas das mesmas letras não diferem entre si, ao nível de $5 \%$ de probabilidade. 


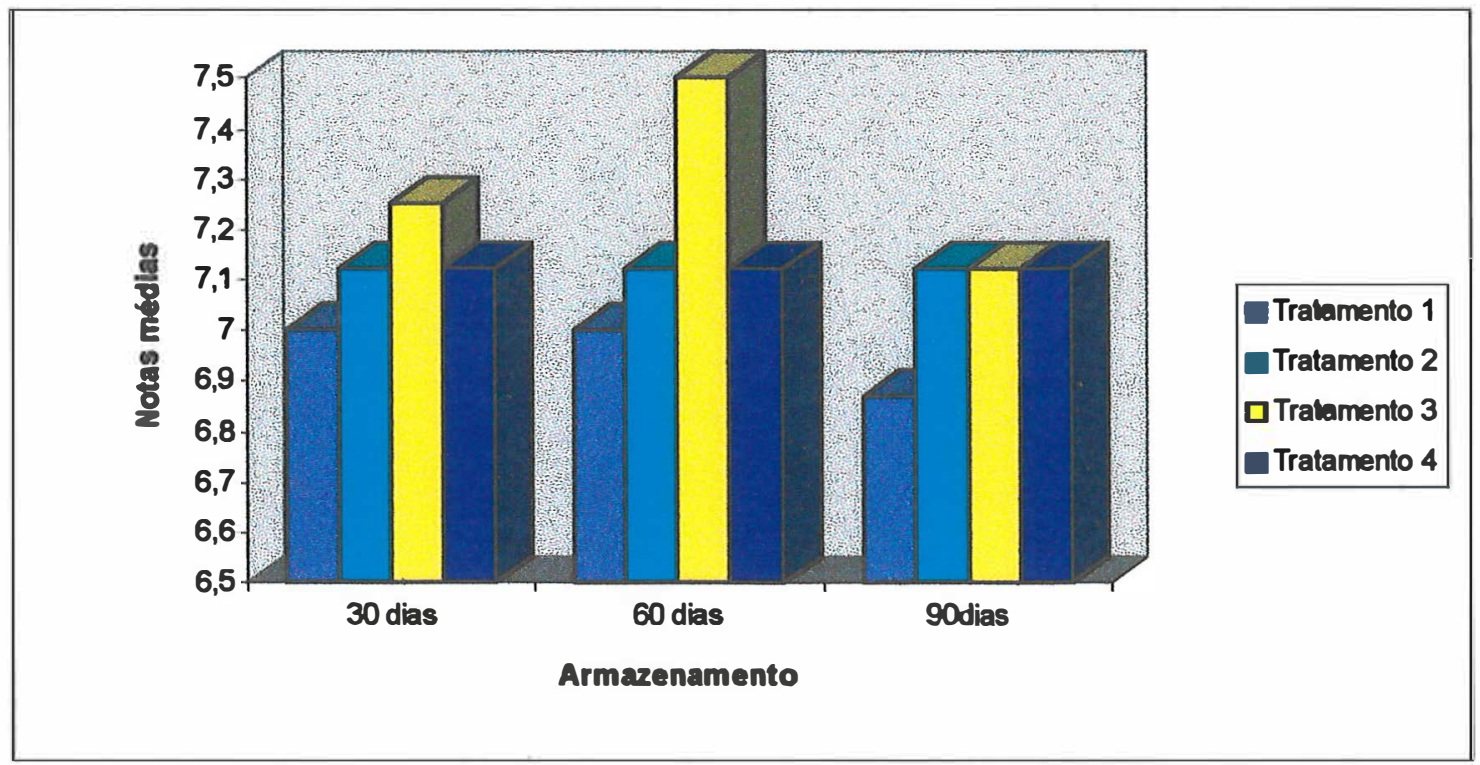

Figura 26. Valores médios obtidos na avaliação sensorial das geleias comuns quanto a textura durante armazenamento- Variedade Guarani.

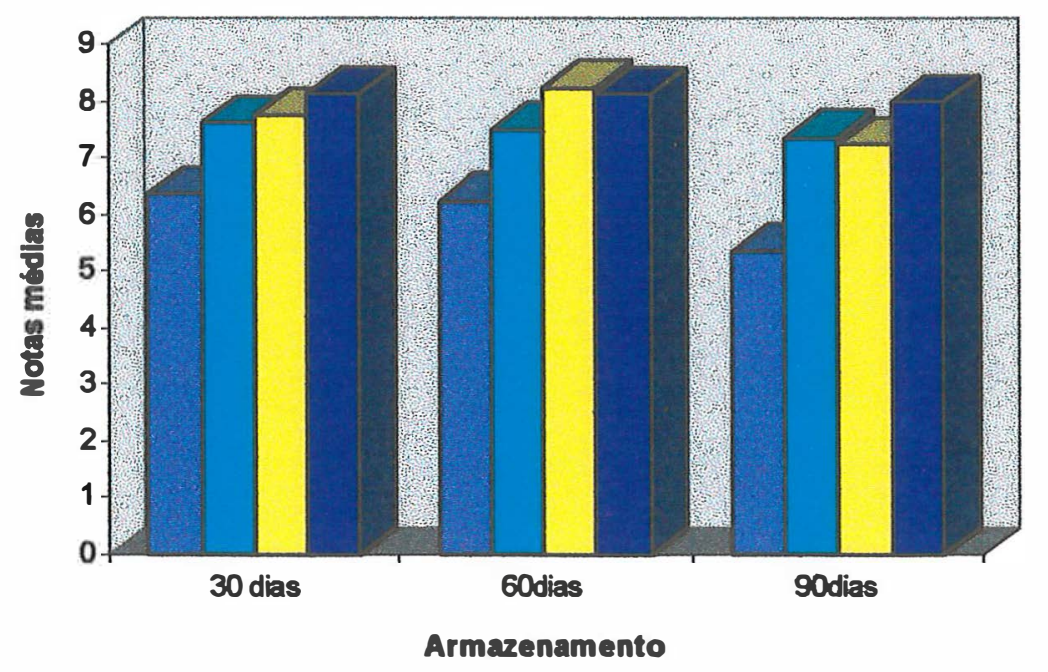

Figura 27. Valores médios obtidos na avaliação sensorial das geléias comuns quanto a textura durante armazenamento - Variedade Oso Grande. 


\subsubsection{Geléia dietética}

\subsubsection{Análises físicas}

Os resultados das análises físicas efetuadas, envolvendo determinações do peso bruto, peso líquido e vácuo das geléias dietéticas durante 180 dias de anmazenamento são apresentados nas Tabelas 16, 17 e 18.

Em relação ao peso bruto e peso líquido das geléias dietéticas (Tabelas 16 e 17), ocorreram diferenças significativas em relação a épocas de annazenamento para as elaboradas com a variedade Guarani e em relação às épocas e tratamentos para as elaboradas com a variedade Oso Grande, porém sem maiores conseqüências para o controle de qualidade dos produtos.

Tabela 16. Peso bruto $(\mathrm{g})$ das geléias dietéticas de morango das duas variedades durante armazenamento.

\begin{tabular}{|c|c|c|c|c|c|c|c|c|c|}
\hline \multirow[b]{2}{*}{ Tempo em dias } & \multicolumn{3}{|c|}{ Guarani } & \multirow[b]{2}{*}{ Médias } & \multicolumn{4}{|c|}{ Oso Grande } & \multirow[b]{2}{*}{ Médias } \\
\hline & T1 & T2 & T3 & & T1 & T2 & T3 & $T 4$ & \\
\hline 0 & 331,95 & 335,65 & 333,65 & $333,75^{6}$ & 332,75 & 331,20 & 345,70 & 346,20 & $338,98^{B}$ \\
\hline 30 & 333,95 & 334,00 & 334,15 & $334,03^{B C}$ & 337,10 & 347,70 & 347,25 & 345,75 & $344,45^{A}$ \\
\hline 60 & 334,95 & 336,45 & 335,70 & $335,70^{\text {ABC }}$ & 342,90 & 345,40 & 347,65 & 346,85 & $345,70^{A}$ \\
\hline 90 & 337,00 & 335,95 & 336,05 & $336,33^{A}$ & 345,05 & 344,75 & 345,45 & 346,00 & $345,31^{A}$ \\
\hline 120 & 334,00 & 334,85 & 336,00 & $334,98^{A B C}$ & 345,70 & 345,30 & 344,85 & 345,40 & $345,31^{A}$ \\
\hline 150 & 334,95 & 335,65 & 337,20 & $335,93^{A B C}$ & 346,00 & 347,20 & 345,95 & 346,80 & $346,48^{A}$ \\
\hline 180 & 335,65 & 337,15 & 336,05 & $336,28^{A B}$ & 337,50 & 345,65 & 345,20 & 346,10 & $343,61^{A}$ \\
\hline Médias & $334,63^{m}$ & $335,67^{\text {A }}$ & $335,55^{\mu}$ & & $341,00^{c}$ & $343,88^{5}$ & $346,00^{A}$ & $346,17^{A}$ & \\
\hline$\overline{F(\text { Epocas) }}$ & $4,66^{* *}$ & & & & $7,06^{*}$ & & & & \\
\hline $\mathrm{F}$ (Tratamentos) & 4,68n.s & & & & $79,87^{\star}$ & & & & \\
\hline
\end{tabular}

$\mathrm{T} 1, \mathrm{~T} 2, \mathrm{~T} 3, \mathrm{~T} 4=$ tratamentos de processamento n.s= não significativo

$* *$ = significativo a nível de $1 \% \quad *=$ significativa a nível de $5 \%$

As médias seguidas das mesmas letras não diferem entre si, ao nível de $5 \%$ de probabilidade. 
Tabela 17. Peso líquido (g) das geléias dietéticas de morango das duas variedades durante armazenamento.

\begin{tabular}{|c|c|c|c|c|c|c|c|c|c|}
\hline \multirow[b]{2}{*}{ Tempo em dias } & \multicolumn{3}{|c|}{ Guarani } & \multirow[b]{2}{*}{ Médias } & \multicolumn{4}{|c|}{ Oso Grande } & \multirow[b]{2}{*}{ Médias } \\
\hline & T1 & T2 & T3 & & T1 & T2 & T3 & T4 & \\
\hline 0 & 217,55 & 221,50 & 219,25 & $219,35^{C}$ & 219,35 & 216,80 & 231,30 & 231,90 & $224,58^{8}$ \\
\hline 30 & 219,55 & 219,60 & 219,75 & $219,63^{B C}$ & 222,70 & 233,30 & 232,85 & 231,35 & $230,05^{A}$ \\
\hline 60 & 220,55 & 222,05 & 221,40 & $221,33^{A B C}$ & 228,50 & 231,00 & 233,25 & 232,45 & $231,30^{A}$ \\
\hline 90 & 222,60 & 221,51 & 221,65 & $221,93^{A}$ & 230,65 & 230,35 & 231,05 & 231,60 & $230,91^{A}$ \\
\hline 120 & 219,60 & 220,45 & 221,70 & $220,58^{A B C}$ & 231,30 & 230,90 & 230,45 & 231,00 & $230,31^{A}$ \\
\hline 150 & 220,50 & 221,25 & 222,80 & $221,53^{A B C}$ & 231,60 & 232,80 & 231,55 & 232,40 & $232,08^{A}$ \\
\hline 180 & 221,25 & 222,75 & 221,65 & $221,88^{A B}$ & 223,10 & 231,25 & 230,80 & 231,70 & $229,21^{A}$ \\
\hline Médias & $220,23^{A}$ & $221,27^{A}$ & $221,17^{A}$ & & $226,60^{C}$ & $229,48^{\square}$ & $231,60^{A}$ & $231,77^{A}$ & \\
\hline F( Épocas) & $0,005^{*}$ & & & & $7,06^{*}$ & & & & \\
\hline F(Tratamentos) & 4,68 n.s & & & & |79,87* & & & & \\
\hline
\end{tabular}

$\mathrm{T} 1, \mathrm{~T} 2, \mathrm{~T} 3, \mathrm{~T} 4=$ tratamentos de processamento

n.s = não significativo

* = significativo a nível de $5 \%$

As médias seguidas das mesmas letras não diferem entre si, ao nível de $5 \%$ de probabilidade.

Em relação ao vácuo das geléias de morango observa-se pela da Tabela 18 que não foram observadas diferenças significativas em relação às épocas $\mathrm{e}$ tratamentos aplicados. Como aconteceu com o vácuo das geléias comuns todos valores encontrados estão acima de 10 pol. $\mathrm{Hg}$, o que indica um bom vácuo para os produtos processados.

O vácuo é dependente das operações de exaustão e da temperatura do produto na operação de fechamento dos vidros. A presença de oxigênio tem um efeito muito prejudicial no que diz respeito a reações oxidativas, as quais resultam em deterioração do ácido ascórbico, escurecimento e alterações 
organolépticas. Vários autores evidenciaram a ação negativa do oxigênio na vida útil de geléias (Fernandes, 1982).

Tabela 18. Vácuo ( pol.Hg ) das geléias dietéticas de morango das duas variedades durante armazenamento.

\begin{tabular}{|c|c|c|c|c|c|c|c|c|c|}
\hline \multirow[b]{2}{*}{$\begin{array}{c}\text { Tempo em } \\
\text { dias }\end{array}$} & \multirow[b]{2}{*}{ T1 } & \multicolumn{2}{|c|}{ Guarani } & \multirow[b]{2}{*}{ Médias } & \multicolumn{4}{|c|}{ Oso Grande } & \multirow[b]{2}{*}{ Médias } \\
\hline & & T2 & T3 & & T1 & T2 & T3 & T4 & \\
\hline 0 & 10,50 & 11,25 & 10,50 & $10,75^{\mu}$ & 10,50 & 12,00 & 11,75 & 11,00 & $11,31^{A}$ \\
\hline 30 & 11,25 & 10,75 & 12,00 & $11,33^{A}$ & 11,50 & 10,50 & 10,75 & 11,50 & $11,06^{A}$ \\
\hline 60 & 11,50 & 10,50 & 10,50 & $10,83^{A}$ & 10,75 & 10,75 & 11,00 & 11,00 & $10,87^{A}$ \\
\hline 90 & 10,75 & 10,50 & 11,00 & $10,75^{A}$ & 11,25 & 12,00 & 11,45 & 11,50 & $11,55^{A}$ \\
\hline 120 & 10,50 & 11,25 & 11,25 & $11,00^{A}$ & 11,50 & 11,50 & 11,25 & 11,00 & $11,31^{A}$ \\
\hline 150 & 11,50 & 11,50 & 11,25 & $11,41^{A}$ & 10,75 & 12,00 & 10,50 & 10,75 & $11,00^{A}$ \\
\hline 180 & 11,75 & 10,50 & 10,50 & $10,91^{A}$ & 11,00 & 12,00 & 12,00 & 11,25 & $11,56^{A}$ \\
\hline Médias & $11,10^{n}$ & $10,89^{A}$ & $11,00^{A}$ & & $11,03^{A}$ & $11,53^{A}$ & $11,24^{A}$ & $11,14^{A}$ & \\
\hline $\bar{F}$ (Epocas) & 4,66 n.s & & & & 10,54 n.s & & & & \\
\hline F(Tratamentos) & 1,04 n.s & & & & 2,26 n.s & & & & \\
\hline
\end{tabular}

$\mathrm{T} 1, \mathrm{~T} 2, \mathrm{~T} 3, \mathrm{~T} 4=$ tratamentos de processamento n.s = não significativo As médias seguidas das mesmas letras não diferem entre si, ao nível de $5 \%$ de probabilidade.

\subsubsection{Análises químicas}

Os resultados correspondentes as determinações de ácido ascórbico, acidez total titulável, $\mathrm{pH}$ e sólidos solúveis (Brix) das geléias dietéticas estão apresentados nas Tabelas 19, 20, 21 e 22 .

Como o ácido ascórbico é destruído em função do tempo e temperatura de aquecimento, os teores de ácido ascórbico nas geléias foram bem menores que os encontrados nos frutos "in natura" ( Tabelas 2 e 19). 
Para as duas variedades (Tabela 19) o ultimo tratamento, ou seja, o 3 para variedade Guarani e o 4 para a variedade Oso Grande foram os que apresentaram maiores teores de ácido ascórbico, uma vez que este foi enriquecido com adição desta vitamiṇa. Para a variedade Guarani apenas o tratamento 3 diferiu dos demais; para a variedade Oso Grande além do tratamento 4 que diferiu dos demais, o tratamento 3 diferiu do 1 .

Tabela 19. Teores de ácido ascórbico (mg/100g amostra) das geléias dietéticas de morango das duas variedades durante armazenamento.

\begin{tabular}{|c|c|c|c|c|c|c|c|c|c|}
\hline \multirow[b]{2}{*}{$\begin{array}{c}\text { Tempo em } \\
\text { dias }\end{array}$} & \multirow[b]{2}{*}{ T1 } & \multicolumn{2}{|c|}{ Guarani } & \multirow[b]{2}{*}{ Médias } & \multicolumn{4}{|c|}{ Oso Grande } & \multirow[b]{2}{*}{ Médias } \\
\hline & & T2 & T3 & & T1 & T2 & T3 & T4 & \\
\hline 0 & 30,00 & 30,00 & 50,00 & $36,66^{A}$ & 30,00 & 33,75 & 35,00 & 50,00 & $37,18^{A}$ \\
\hline 30 & 30,00 & 30,00 & 50,00 & $36,66^{A}$ & 30,00 & 30,00 & 35,00 & 50,00 & $36,25^{A}$ \\
\hline 60 & 27,50 & 27,50 & 40,00 & $36,66^{B}$ & 30,00 & 30,00 & 33,75 & 47,50 & $35,31^{\text {AB }}$ \\
\hline 90 & 20,00 & 25,00 & 40,00 & $28,33^{C}$ & 28,75 & 27,50 & 32,50 & 42,50 & $32,81^{\mathrm{BC}}$ \\
\hline 120 & 20,00 & 25,00 & 37,50 & $27,50^{\mathrm{Cu}}$ & 25,00 & 25,00 & 30,00 & 40,00 & $30,00^{\mathrm{CU}}$ \\
\hline 150 & 17,50 & 25,00 & 32,50 & $25,00^{t}$ & 22,50 & 25,00 & 27,50 & 37,50 & $28,12^{\mathrm{V}}$ \\
\hline 180 & 15,00 & 22,50 & 30,00 & $22,50^{t}$ & 20,00 & 22,50 & 27,50 & 37,50 & $26,87^{\circ}$ \\
\hline Médias & $22,85^{\circ}$ & $26,42^{\mathrm{B}}$ & $40,00^{A}$ & & $26,60^{c}$ & $27,67^{\mathrm{CB}}$ & $31,60^{B}$ & $43,57^{A}$ & \\
\hline F( Epocas) & $61,60^{\star \star}$ & & & & $101,06^{*}$ & & & & \\
\hline $\mathrm{F}$ (Tratamentos) & $384,80^{\star \star}$ & & & & $32,02^{\star \star}$ & & & & \\
\hline
\end{tabular}

$\mathrm{T} 1, \mathrm{~T} 2, \mathrm{~T} 3, \mathrm{~T} 4=$ tratamentos de processamento

*= significativo a nível de $5 \%$

** = significativo a nível de $1 \%$

As médias seguidas das mesmas letras não diferem entre si, ao nível de $5 \%$ de probabilidade.

Com relação às épocas de avaliação observa-se para as duas variedades que as maiores perdas de ácido ascórbico ocorreram a partir de dois meses de armazenamento (Figuras 28 e 29).

Durante os 180 dias de armazenamento o teor de ácido ascórbico sofreu uma redução de $38,6 \%$ para a variedade Guarani e $26,40 \%$ para a variedade 
Oso Grande. Observando estes resultados pode-se concluir que no final de 180 dias de armazenamento os teores de ácido ascórbico podem ser considerados muito bons.

Os teores de ácido ascórbico obtidos (Tabela 19) são em geral muito superiores aos obtidos por Marquina et al. (1987) que encontraram teores médios de $13,37 \mathrm{mg} / 100 \mathrm{~g}$ de geléia dietética de morango. Os resultados encontrados são semelhantes aos obtidos para geléias comuns, mesmo com a etapa adicional de processamento (esterilização comercial), aplicada para a melhor conservação das geléias dietéticas. Em relação às variedades observa-se pela Figura 30, que de um modo geral a variedade Oso Grande apresentou teores de ácido ascórbico superiores à Guarani.

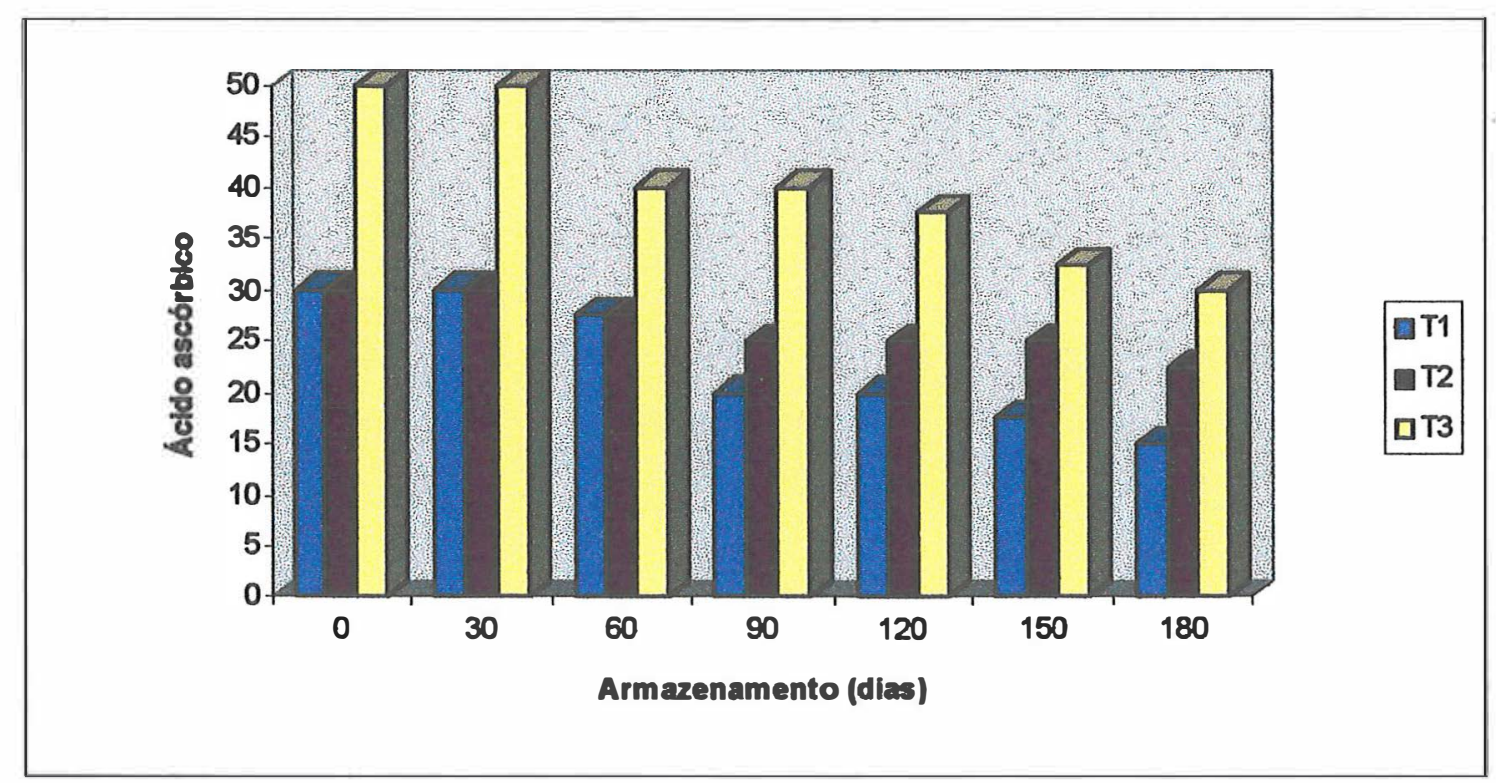

Figura 28. Variação dos teores de ácido ascórbico das geléias dietéticas $(\mathrm{mg} / 100 \mathrm{~g}$ amostra) de acordo com os períodos de armazenamento- Variedade Guarani. 


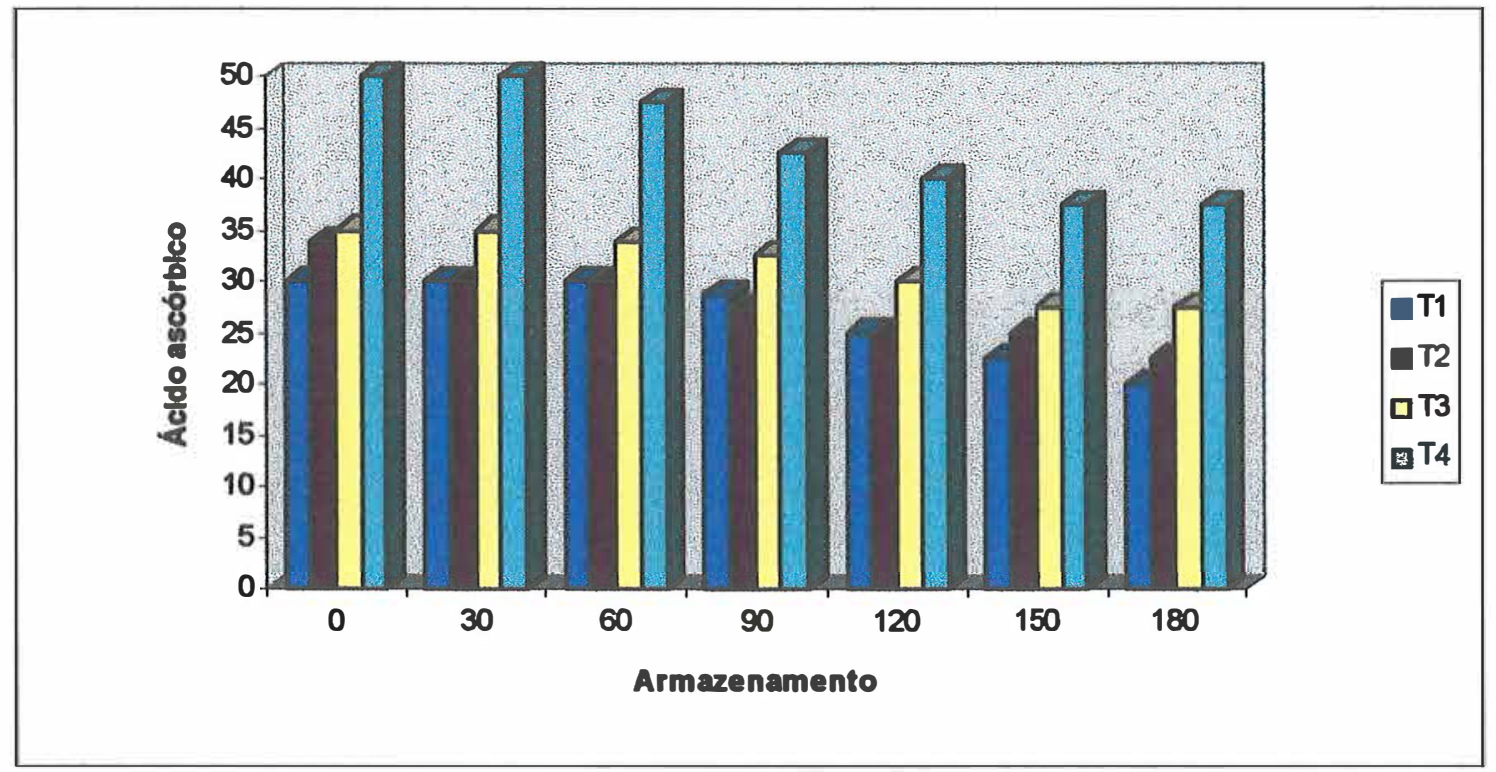

Figura 29. Variação dos teores de ácido ascórbico das geléias dietéticas $(\mathrm{mg} / 100 \mathrm{~g}$ amostra) de acordo com os períodos de armazenamento- Variedade Oso Grande.

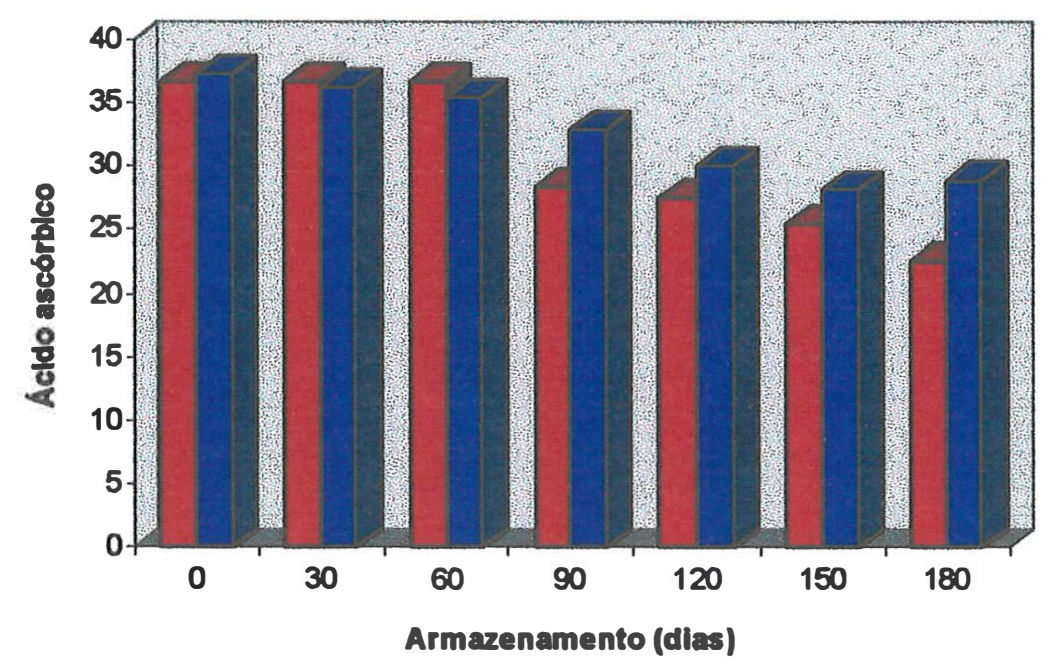

Guarani

Oso Grande

Figura 30. Comparação entre as geléias dietéticas de morango das duas variedades com relação ao teor de ácido ascórbico (mg/100g amostra) durante armazenamento. 
Com relação a acidez total titulável (Tabela 20), o tratamento 1 para as duas variedades foi o que apresentou o menor teor de acidez, o que era esperado, já que neste tratamento (polpa de morango + edulcorantes + pectina +fosfato tricálcio) não foi adicionado ácido cítrico ou ascórbico. Apenas o tratamento 1 apresentou diferenças significativas em relação aos demais tratamentos.

Durante os períodos de armazenamento, para a variedade Guarani (Figura 31) ocorreram pequenas quedas nos teores de acidez $(0,31$ para $0,30 \mathrm{~g}$ de ácido cítrico/100g de geléia); para a variedade Oso Grande (Figura 32) ocorreram também quedas nos teores de acidez $(0,27$ para $0,25 \mathrm{~g}$ de ácido cítrico/100g de geléia). Esta queda nos teores de acidez total titulável pode ser justificada com a diminuição dos teores de ácido ascórbico, já que este é um dos ácidos presentes na determinação da acidez total titulável.

Observa-se pela Figura 33, que as geléias obtidas com a variedade Guarani apresentaram teores superiores de acidez, o que já era esperado, já que esta variedade é mais ácida do que a Oso Grande.

Com relação ao $\mathrm{pH}$ observa-se pela Tabela 21, que para a variedade Guarani todos os tratamentos diferiram entre si; para a variedade Oso Grande os tratamentos 1 e 3 diferiram dos tratamentos 2 e 4 que não diferiram entre si.

Em geral os resultados obtidos são semelhantes aos obtidos por Campos \& Cândido (1995) que avaliaram o pH de várias amostras de geléias dietéticas e encontraram valores entre 3,90 e 4,10 e aos obtido por Spozywczy (1992) com valores ao redor de 4,5 . 
Tabela 20. Teores de acidez total titulável (g ácido cítrico/ $100 \mathrm{~g}$ amostra) das geléias dietéticas de morango das duas variedades durante armazenamento.

\begin{tabular}{|c|c|c|c|c|c|c|c|c|c|}
\hline \multirow[b]{2}{*}{ Tempo em dias } & \multicolumn{3}{|c|}{ Guarani } & \multirow[b]{2}{*}{ Médias } & \multicolumn{4}{|c|}{ Oso Grande } & \multirow[b]{2}{*}{ Médias } \\
\hline & T1 & T2 & T3 & & T1 & T2 & T3 & T4 & \\
\hline 0 & 0,29 & 0,31 & 0,32 & $0,31^{\mathrm{AD}}$ & 0,21 & 0,28 & 0,28 & 0,30 & $0,27^{A}$ \\
\hline 30 & 0,29 & 0,31 & 0,31 & $0,30^{\text {AB }}$ & 0,21 & 0,27 & 0,28 & 0,27 & $0,26^{B C D}$ \\
\hline 60 & 0,29 & 0,31 & 0,31 & $0,30^{\text {AB }}$ & 0,25 & 0,27 & 0,26 & 0,27 & $0,26^{A B}$ \\
\hline 90 & 0,29 & 0,31 & 0,30 & $0,30^{\mathrm{B}}$ & 0,25 & 0,26 & 0,26 & 0,26 & $0,26^{b C}$ \\
\hline 120 & 0,29 & 0,32 & 0,31 & $0,30^{A B}$ & 0,25 & 0,25 & 0,25 & 0,26 & $0,25^{(v)}$ \\
\hline 150 & 0,31 & 0,32 & 0,29 & $0,31^{\text {AB }}$ & 0,25 & 0,25 & 0,25 & 0,25 & $0,25^{\mathrm{V}}$ \\
\hline 180 & 0,32 & 0,32 & 0,30 & $0,31^{A}$ & 0,24 & 0,25 & 0,25 & 0,25 & $0,25^{\mathrm{V}}$ \\
\hline Médias & $0,29^{8}$ & $0,31^{\bar{R}}$ & $0,31^{\pi-}$ & & $0,24^{8}$ & $0,26^{\pi-}$ & $0,26^{\pi}$ & $0,27^{\pi}$ & \\
\hline F( Epocas) & $3,08^{*}$ & & & & $17,88^{\text {nth }}$ & & & & \\
\hline F(Tratamentos) & $42,67^{\star}$ & & & & $91,14^{\star *}$ & & & & \\
\hline
\end{tabular}

$\mathrm{T} 1, \mathrm{~T} 2, \mathrm{~T} 3, \mathrm{~T} 4=$ tratamentos de processamento

** = significativo a nível de $1 \% *$ = significativo a nível de $5 \%$

As médias seguidas das mesmas letras não diferem entre si, ao nível de $5 \%$ de probabilidade.

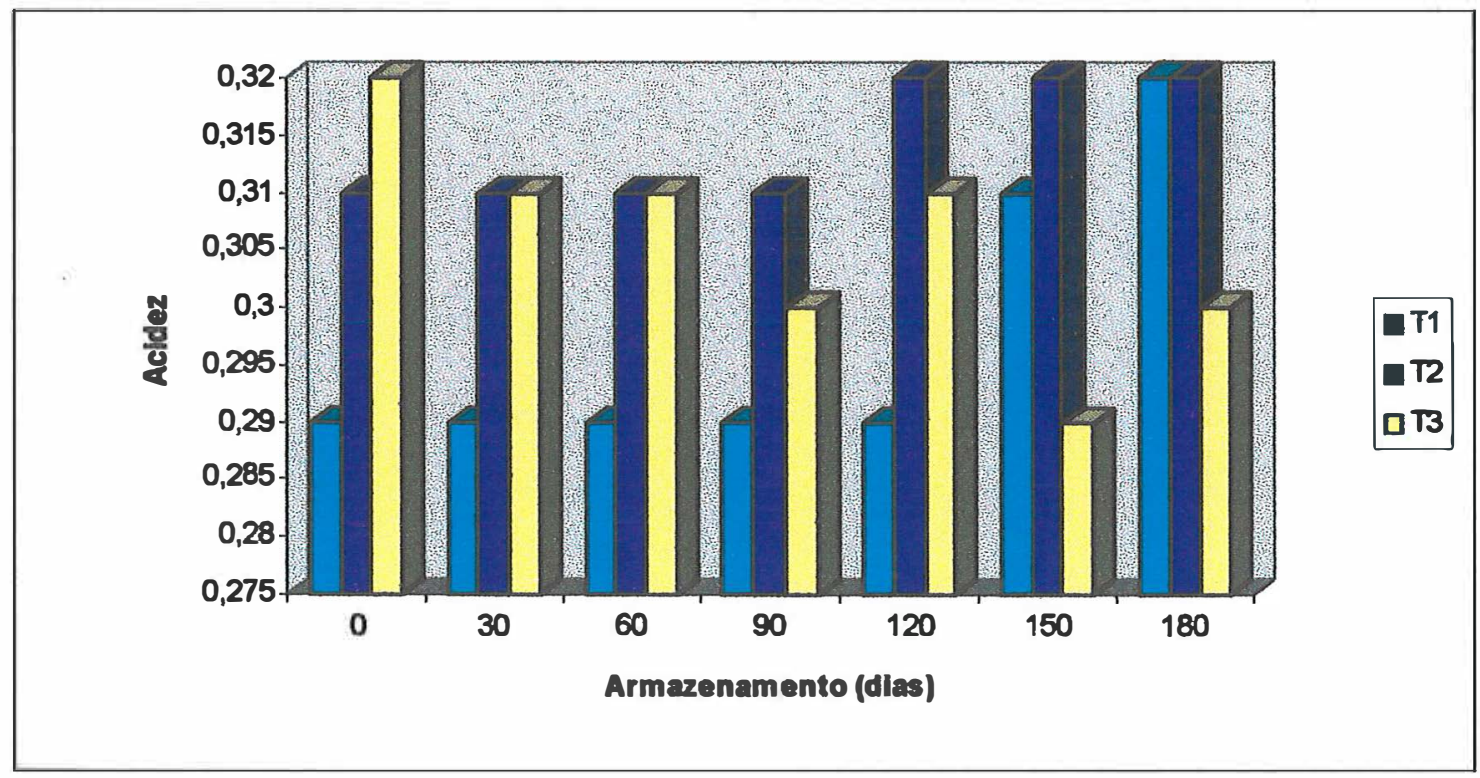

Figura 31. Variação dos teores de acidez total titulável ( $\mathrm{g}$ de ácido cítrico/100g amostra) das geléias dietéticas de acordo com os períodos de armazenamento- Variedade Guarani. 


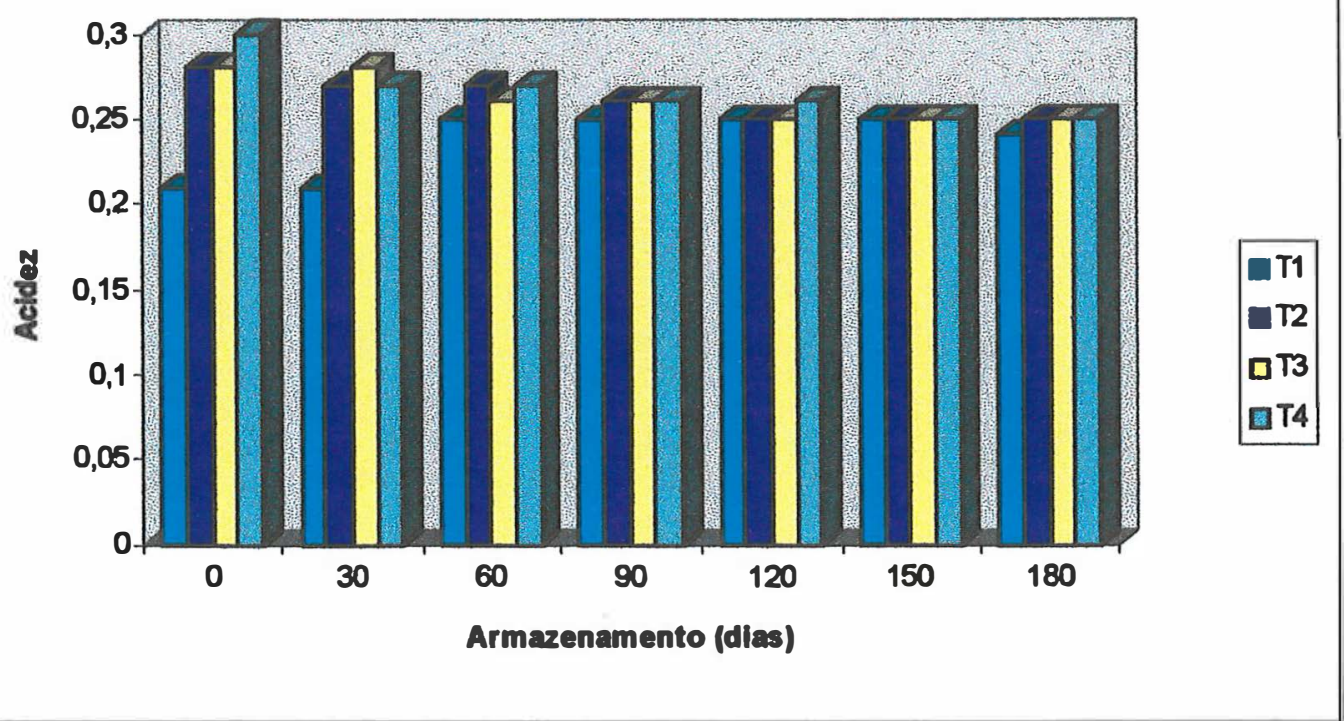

Figura 32. Variação dos teores de acidez total titulável das geléias dietéticas ( $\mathrm{g}$ de ácido cítrico/100g amostra) de acordo com os períodos de armazenamento- Variedade Oso Grande.

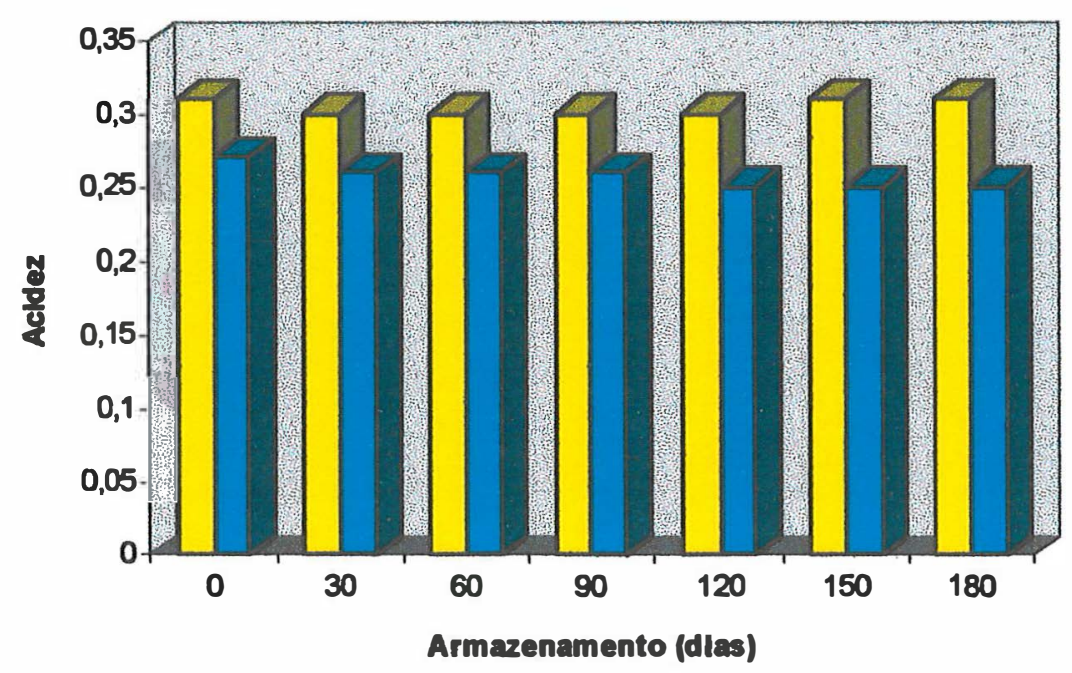

口Guarani

Oso Grande

Figura 33. Comparação entre as geléias dietéticas de morango das duas variedades com relação ao teor de acidez total titulável ( $\mathrm{g}$ ácido cítrico/100g da amostra) durante armazenamento. 
Tabela 21. Valores de $\mathrm{pH}$ das geléias dietéticas de morango das duas variedades durante armazenamento.

\begin{tabular}{|c|c|c|c|c|c|c|c|c|c|}
\hline \multirow[b]{2}{*}{$\begin{array}{c}\text { Tempo em } \\
\text { dias }\end{array}$} & \multirow[b]{2}{*}{ T1 } & \multicolumn{2}{|c|}{ Guarani } & \multirow[b]{2}{*}{ Médias } & \multicolumn{4}{|c|}{ Oso Grande } & \multirow[b]{2}{*}{ Médias } \\
\hline & & T2 & T3 & & T1 & T2 & T3 & T4 & \\
\hline 0 & 4,13 & 4,11 & 4,00 & $4,08^{A}$ & 4,18 & 4,20 & 4,05 & 4,16 & $4,15^{A}$ \\
\hline 30 & 4,12 & 4,11 & 4,00 & $4,08^{A}$ & 4,16 & 4,00 & 4,03 & 4,14 & $4,08^{b}$ \\
\hline 60 & 4,11 & 3,92 & 3,89 & $3.97^{b}$ & 4,14 & 3,92 & 3,90 & 3,90 & $3,97^{c}$ \\
\hline 90 & 3,77 & 3,88 & 3,88 & $3,84^{C}$ & 4,11 & 3,91 & 3,90 & 3,90 & $3,95^{\circ}$ \\
\hline 120 & 3,73 & 3,85 & 3,86 & $3,81^{\mathrm{V}}$ & 4,11 & 3,90 & 3,87 & 3,84 & $3,93^{t}$ \\
\hline 150 & 3,70 & 3,83 & 3,86 & $3,80^{t}$ & 4,11 & 3,87 & 3,87 & 3,83 & $3,92^{r}$ \\
\hline 180 & 3,70 & 3,78 & 3,86 & $3,78^{r}$ & 4,11 & 3,86 & 3,87 & 3,83 & $3,91^{r}$ \\
\hline Médias & $3,92^{\mu}$ & $3,90^{5}$ & $\overline{3,89^{4}}$ & & $4,13^{A}$ & $3,95^{5}$ & $3,92^{c}$ & $3,94^{\mathrm{B}}$ & \\
\hline F( Épocas) & $2374^{\star \star \star}$ & & & & $4316^{\star \star}$ & & & & \\
\hline F(Tratamentos) & $876^{\star \star}$ & & & & $3992^{\star \star}$ & & & & \\
\hline
\end{tabular}

$\mathrm{T} 1, \mathrm{~T} 2, \mathrm{~T} 3, \mathrm{~T} 4=$ tratamentos de processamento.

$* *$ = significativo a nivel de $1 \%$.

As médias seguidas das mesmas letras não diferem entre si, ao nível de $\mathbf{5 \%}$ de probabilidade.

Com relação ao tempo de armazenamento houve queda do $\mathrm{pH}$ das geléias dietéticas durante os 180 dias de armazenamento. Para a variedade Guarani as maiores variações ocorreram a partir de 60 dias de armazenamento e para a variedade Oso Grande a partir em 30 dias de armazenamento (Figuras 34 e 35). Esta diminuição significativa dos valores de $\mathrm{pH}$ pode também ser justificada pela dissociação dos ácidos. Segundo Moore (1976), com a temperatura e tempo de estocagem ocorre dissociação dos ácidos, aumentando o número de ions hidrogênio, conseqüentemente diminuindo o $\mathrm{pH}$.

Comparando-se as duas variedades observa-se pela Figura 36, que as geléias obtidas com a variedade Guarani apresentaram valores de $\mathrm{pH}$ mais baixos, o que já era esperado, já que esta variedade é mais ácida do que a Oso Grande. 


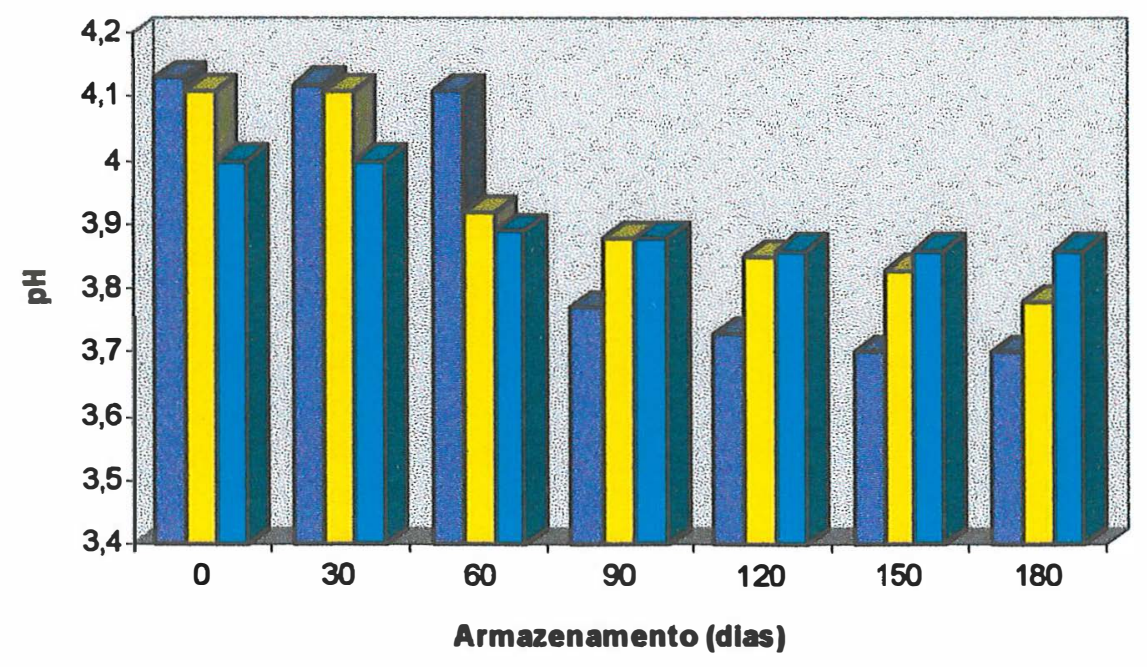

Figura 34. Variação dos valores de pH das geléias dietéticas de acordo com os períodos de armazenamento- Variedade Guarani.

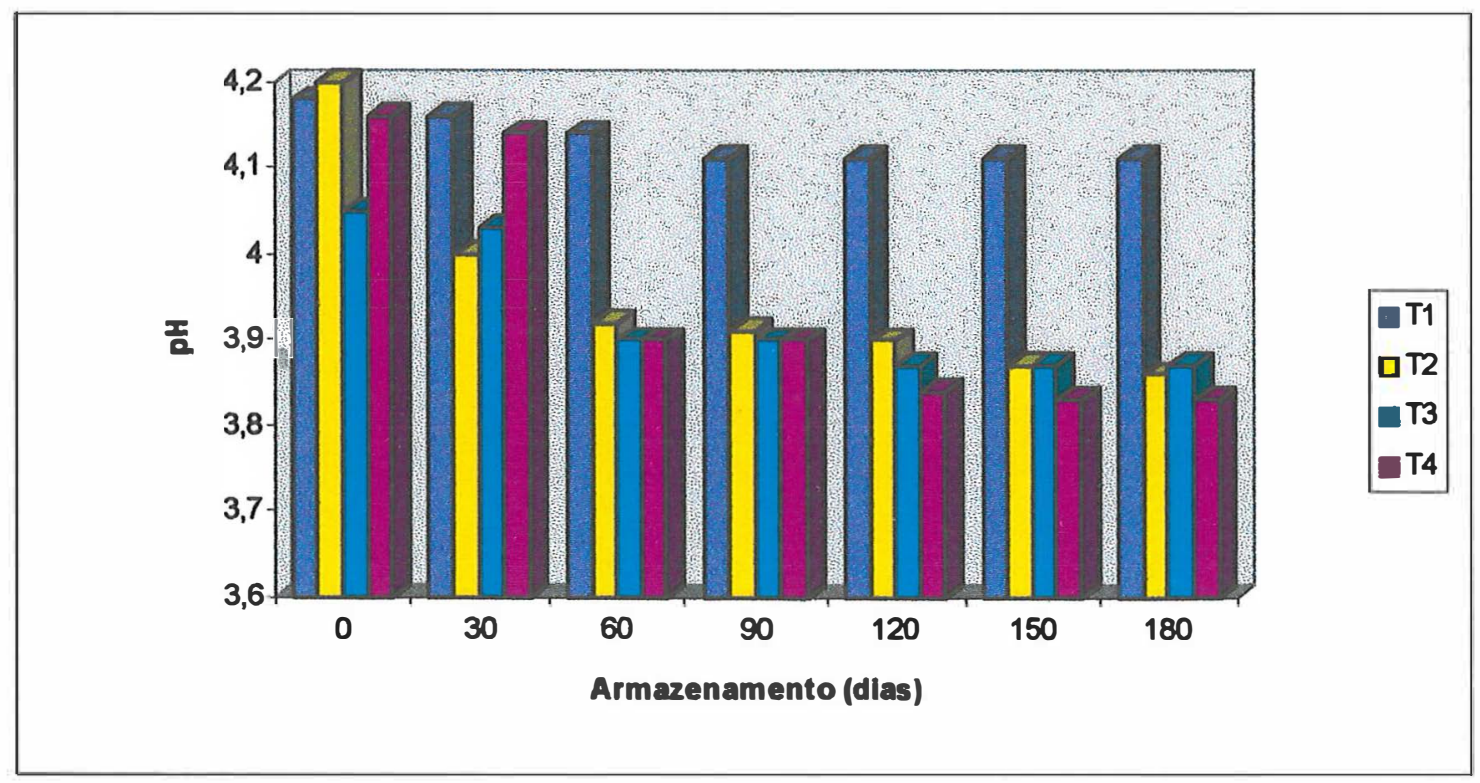

Figura 35. Variação dos valores de pH das geléias dietéticas de acordo com os períodos de armazenamento- Variedade Oso Grande. 


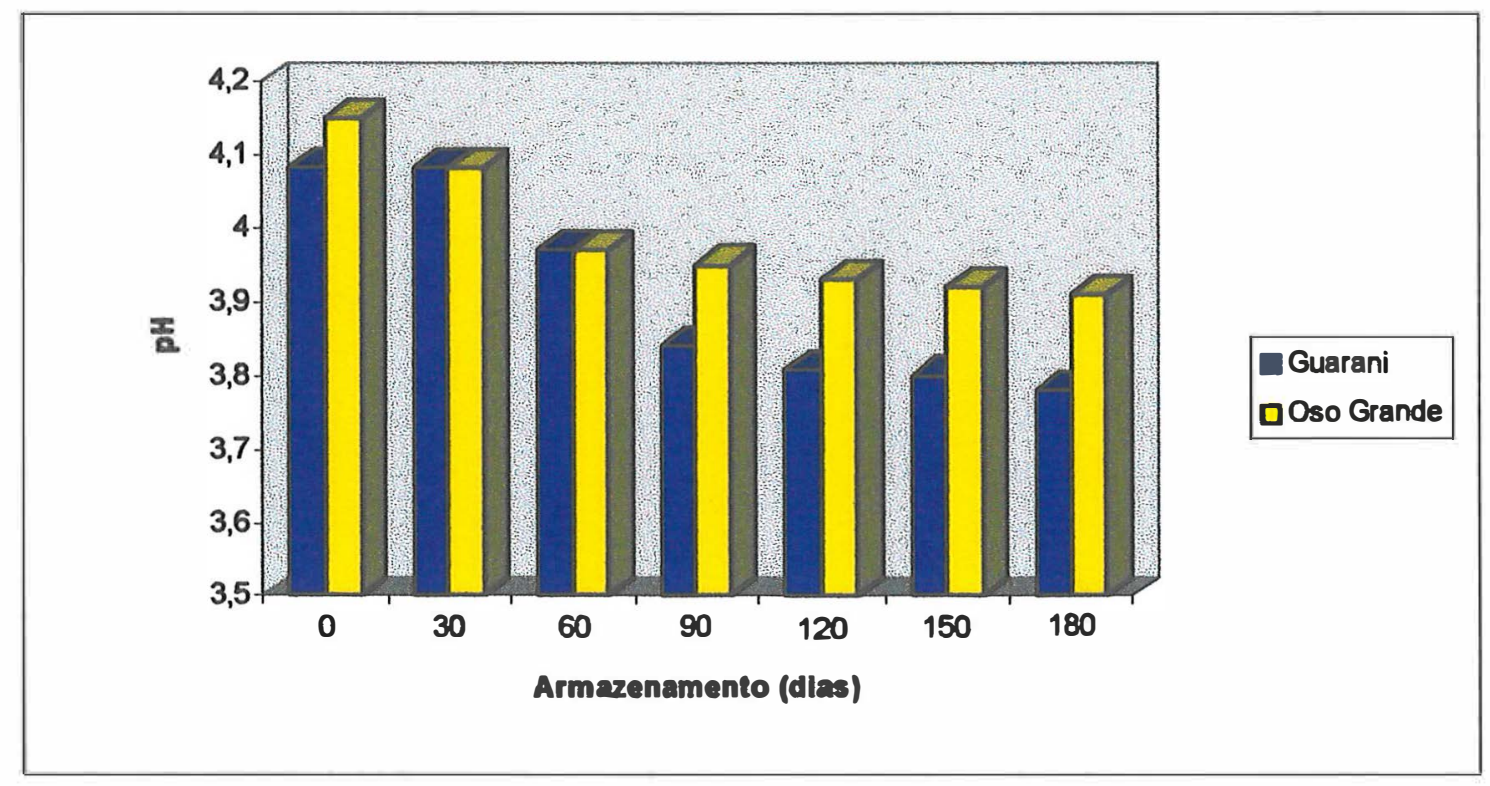

Figura 36. Comparação entre as geléias dietéticas de morango das duas variedades com relação ao pH durante armazenamento.

Com relação ao teor de sólidos solúveis (Tabela 22), os resultados mostraram que para as duas variedades o último tratamento, ou seja, o 3 para a variedade Guarani e o 4 para a Oso Grande diferiu dos demais tratamentos e apresentaram a menor média $(17,00)$. Em geral os resultados obtidos são semelhantes aos obtidos por Campos \& Cândido (1995).

Em relação às épocas de avaliação para a variedade Guarani as maiores variações ocorreram a partir de dois meses de armazenamento (Figura 37). Para a variedade Oso Grande não ocorreram diferenças significativas entre as diferentes épocas de avaliação durante o período de armazenamento (Figura 38). Com relação às variedades (Figura 39) nos dois primeiros meses as geléias elaboradas com a variedade Guarani apresentaram teores superiores de sólidos solúveis em relação a variedade Oso Grande, sendo que a partir de sessenta dias de armazenamento o contrário foi observado. 
Tabela 22. Teores de sólidos solúveis (Brix) das geléias dietéticas de morango das duas variedades durante armazenamento.

\begin{tabular}{|c|c|c|c|c|c|c|c|c|c|}
\hline \multirow[b]{2}{*}{$\begin{array}{l}\text { Tempo em } \\
\text { dias }\end{array}$} & \multirow[b]{2}{*}{ T1 } & \multicolumn{2}{|c|}{ Guarani } & \multirow[b]{2}{*}{ Médias } & \multicolumn{4}{|c|}{ Oso Grande } & \multirow[b]{2}{*}{ Médias } \\
\hline & & T2 & T3 & & T1 & T2 & T3 & T4 & \\
\hline 0 & 19,00 & 19,00 & 17,00 & $18,33^{A}$ & 18,00 & 18,00 & 18,00 & 17,00 & $17,75^{\AA-}$ \\
\hline 30 & 19,00 & 19,00 & 17,00 & $18,33^{A}$ & 18,00 & 18,00 & 18,00 & 17,00 & $17,75^{A}$ \\
\hline 60 & 18,00 & 18,00 & 17,00 & $17,67^{\mathrm{B}}$ & 18,00 & 18,00 & 18,00 & 17,00 & $17,75^{A}$ \\
\hline 90 & 18,00 & 18,00 & 17,00 & $17,67^{\mathrm{b}}$ & 18,00 & 18,00 & 18,00 & 17,00 & $17,75^{A}$ \\
\hline 120 & 18,00 & 18,00 & 17,00 & $17,67^{b}$ & 18,00 & 18,00 & 18,00 & 17,00 & $17,75^{A}$ \\
\hline 150 & 18,00 & 18,00 & 17,00 & $17,67^{\mathrm{B}}$ & 18,00 & 18,00 & 18,00 & 17,00 & $17,75^{A}$ \\
\hline 180 & 18,00 & 18,00 & 17,00 & $17,67^{\mathrm{H}}$ & 18,00 & 18,00 & 18,00 & 17,00 & $17,75^{A}$ \\
\hline Médias & $18,29^{A}$ & $18,29^{\AA}$ & $17,00^{8}$ & & $18,00^{A}$ & $18,00^{A}$ & $18,00^{A}$ & $17,00^{8}$ & \\
\hline $\bar{F}$ (Épocas) & $3214^{\star \star \hbar}$ & & & & $4314^{\text {th }}$ & & & & \\
\hline F(Tratamentos) & $1124^{\text {*t }}$ & & & & 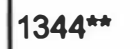 & & & & \\
\hline
\end{tabular}

$\mathrm{T} 1, \mathrm{~T} 2, \mathrm{~T} 3, \mathrm{~T} 4=$ tratamentos de processamento.

** = significativo a nível de $1 \%$.

As médias seguidas das mesmas letras não diferem entre si, ao nível de $5 \%$ de probabilidade

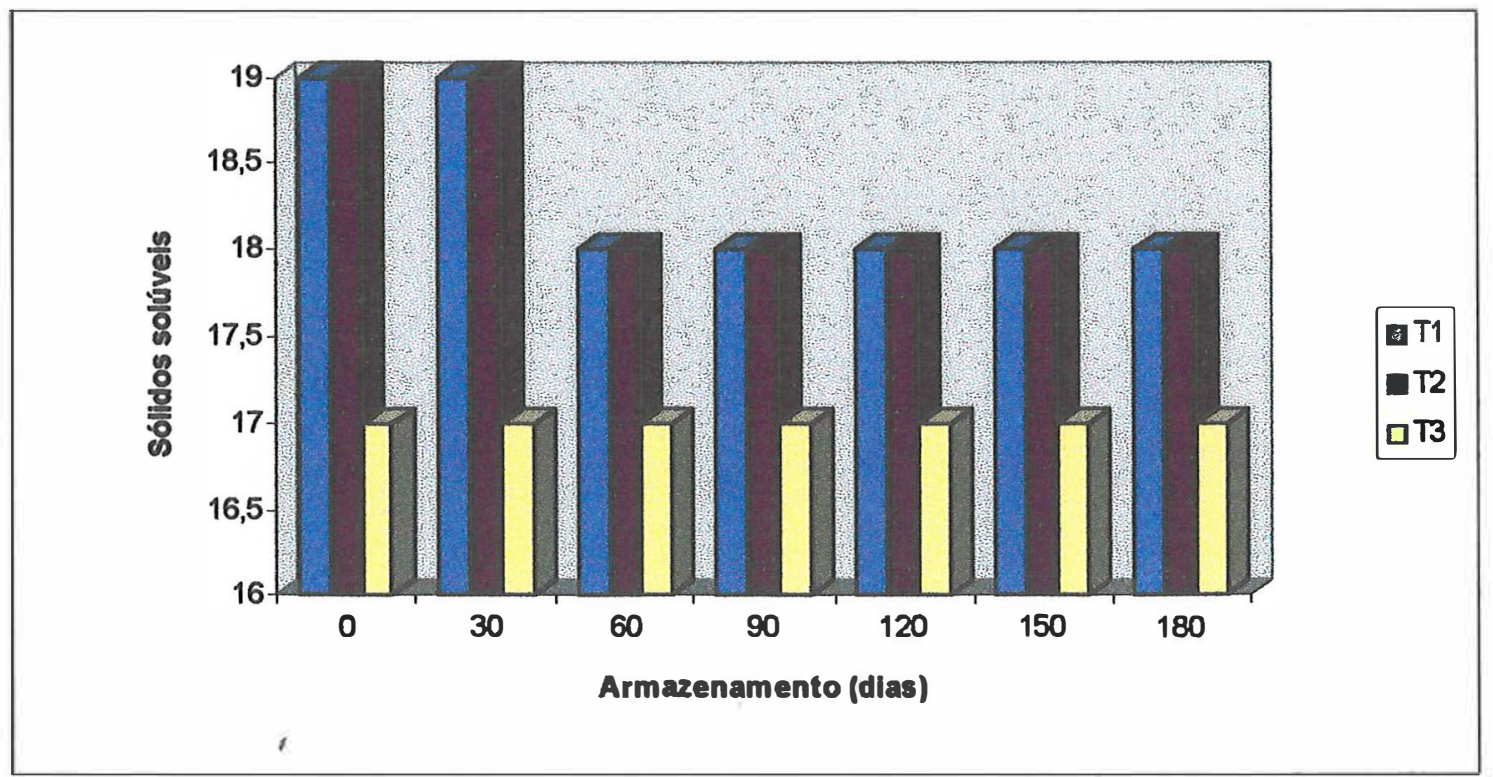

Figura 37. Variação dos teores de sólidos solúveis (Brix) das geléias dietéticas de acordo com os períodos de armazenamento- Variedade Guarani. 


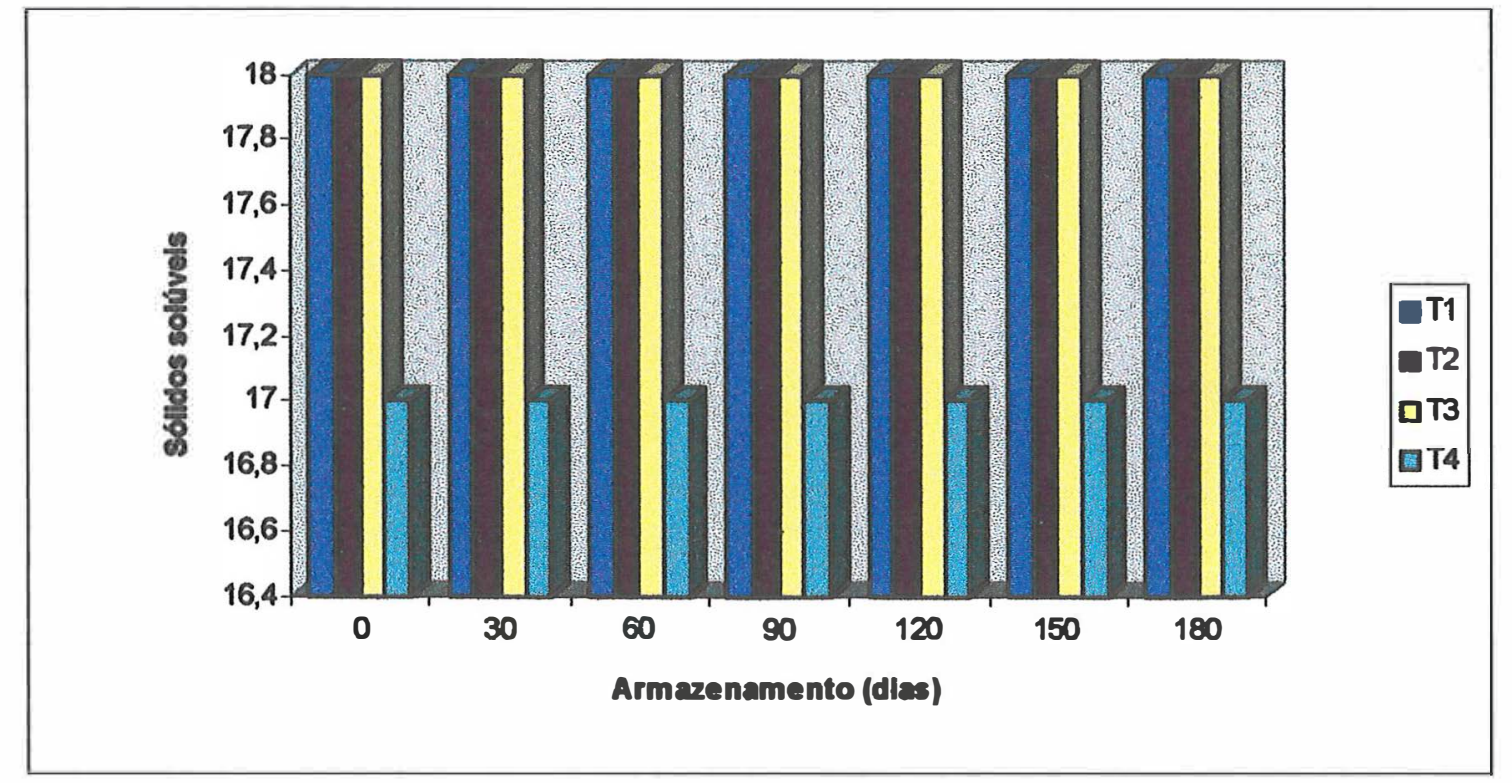

Figura 38. Variação dos teores de sólidos solúveis (Brix) das geléias dietéticas de acordo com os períodos de armazenamento- Variedade Oso Grande.

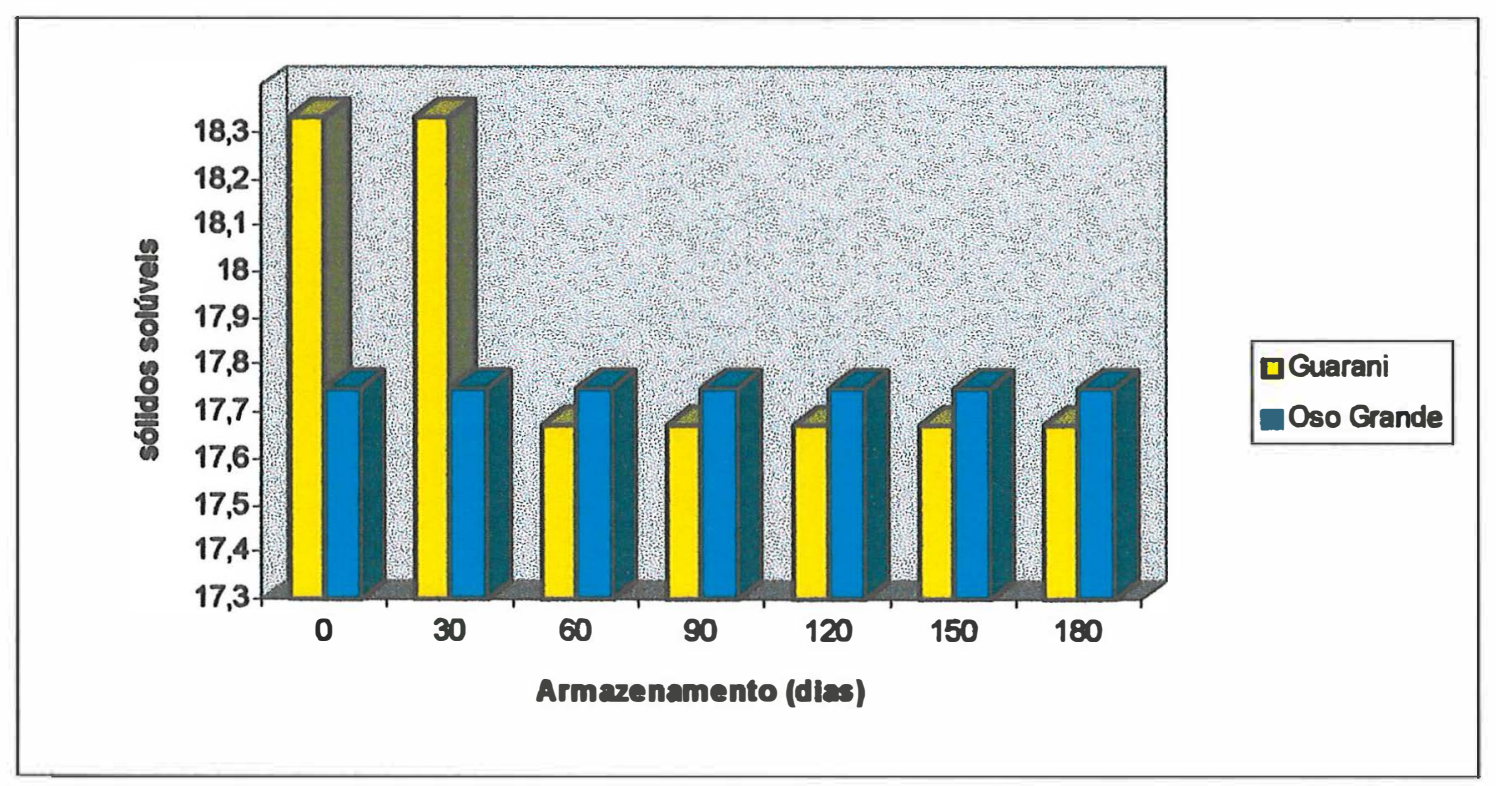

Figura 39. Comparação entre as geléias de morango dietéticas das duas variedades com relação ao sólidos solúveis (Brix) durante armazenamento. 


\subsubsection{Análises sensoriais}

Os resultados da avaliação subjetiva do sabor, cor e textura das geleías dietéticas durante armazenamento (30, 60 e 90 dias) são apresentados nas Tabelas 23, 24, 25, 26,27 e 28 .

Em relação ao sabor das geléias dietéticas observa-se pela Tabela 23 que aos trinta dias de armazenamento, para a variedade Guarani,o tratamento 1(polpa de morango + pectina + edulcorantes + fosfato tri-cálcio) diferiu dos demais tratamentos, sendo este considerado como o pior tratamento (Figura 40). Aos sessenta e noventa dias de armazenamento não ocorreram diferenças significativas para esta variedade.

Para a variedade Oso Grande nas três épocas de avaliação, os tratamentos 1 e 2 diferiram dos tratamentos 3 e 4 . De um modo geral, os tratamentos 3 (polpa de morango + pectina +edulcorantes + fosfato tri-cálcio + sorbato de potássio + cloreto de estanho + ácido ascórbico) para a variedade Guarani (Figura 40) e o 4 (polpa de morango + pectina +edulcorantes + fosfato tri-cálcio + sorbato de potássio + ácido cítrico +cloreto de estanho + ácido ascórbico) foram os preferidos pelos provadores obetendo as maiores médias para este atributo (Figura 41).

Quanto aos períodos de armazenamento, observa-se pela Tabela 24, que não ocorreram diferenças estatisticas significativas durante os 90 dias de armazenamento, portanto as geléias permaneceram estáveis durante o armazenamento com relação ao sabor. Ocorreram diferenças significativas em relação às variedades estudadas, sendo 
que as geléias elaboradas com a variedade Guarani foram as preferidas pelos provadores obtendo a média de 6,17 .

Tabela 23. Avaliação sensorial do sabor das geléias dietéticas de morango das duas variedades durante amazenamento.

\begin{tabular}{|c|c|c|c|c|c|c|}
\hline \multirow{3}{*}{ Tratamentos } & \multicolumn{2}{|c|}{ MÍDDIAS } & \multicolumn{2}{|c|}{ DAS ANÁ LISES } & \multirow{2}{*}{\multicolumn{2}{|c|}{90 DIAS }} \\
\hline & \multicolumn{2}{|c|}{30 DIAS } & \multicolumn{2}{|c|}{60 DIAS } & & \\
\hline & Guarani & Oso Grande & Guarani & Oso Grande & \multicolumn{2}{|c|}{ Oso Grande } \\
\hline 1 & $5,62^{B}$ & $4,10^{C}$ & $6,10^{A}$ & $4,25^{C^{-}}$ & $5,70^{\bar{A}}$ & $4,10^{C}$ \\
\hline 2 & $6,72^{A}$ & $5,50^{\mathrm{C}}$ & $6,12^{A}$ & $4,80^{C}$ & $6,00^{A}$ & $4,60^{C}$ \\
\hline 3 & $7,12^{\mathrm{A}}$ & $5,37^{\mathrm{AB}}$ & $6,12^{A}$ & $5,37^{\mathrm{AB}}$ & $5,87^{\mathrm{A}}$ & $5,25^{\mathrm{AB}}$ \\
\hline 4 & & $6,37^{A}$ & & $6,12^{A}$ & & $6,12^{A}$ \\
\hline F (trat.) & $13,88^{*}$ & $10,73^{* *}$ & 12,34 n.s & $4,12^{* *}$ & $1,28 \mathrm{n} . \mathrm{s}$ & $7,89 * *$ \\
\hline F (provad.) & $21,69 * *$ & $11,79^{* *}$ & $21,69 * *$ & $8,89^{*}$ & $7,41^{* *}$ & $9,87^{*}$ \\
\hline
\end{tabular}

n.s= não significativo

** = significativo a nivel de $1 \%$ - *= significativo a nivel de $5 \%$

As médias seguidas das mesmas letras não diferem entre si, ao nível de $5 \%$ de probabilidade.

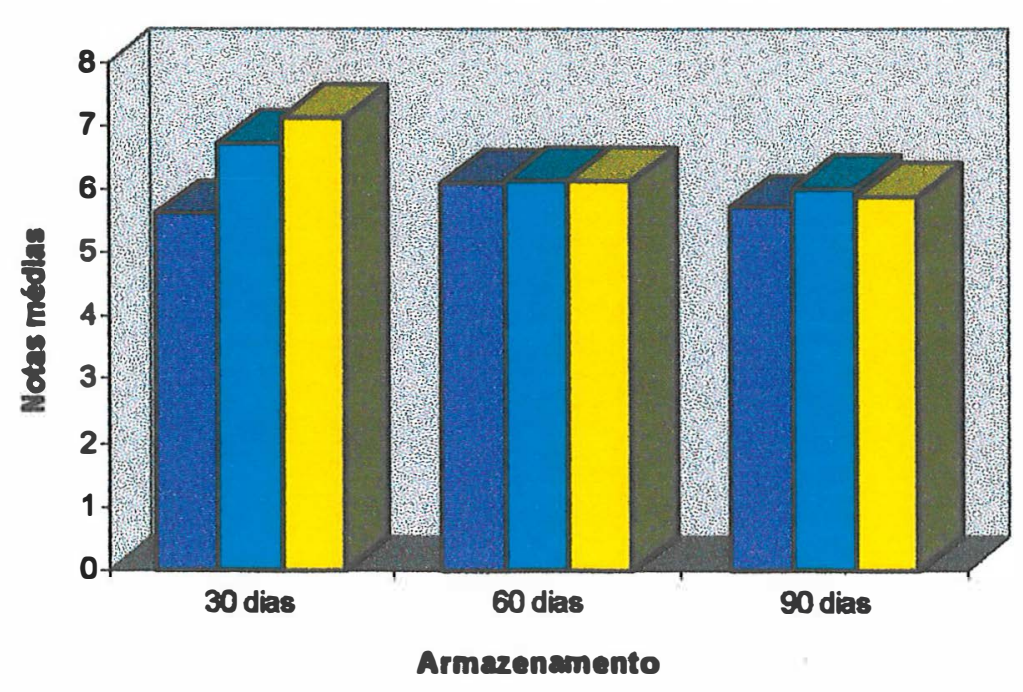

Tratamento 1

Tratamento 2

Tratamento 3

Figura 40. Valores médios obtidos na avaliação sensorial das geléias dietéticas quanto ao sabor durante armazenamento- Variedade Guarani. 
Tabela 24. Comparação entre as geléias dietéticas de morango das duas variedades com relação ao sabor durante o armazenamento.

\begin{tabular}{c|cc}
\hline Épocas de avaliação & \multicolumn{2}{|c}{ Médias das Análises } \\
\cline { 2 - 3 } (dias) & Guarani & Oso Grande \\
\hline 30 & $6,37^{\mathrm{A}}$ & $5,34^{\mathrm{A}}$ \\
60 & $6,29^{\mathrm{A}}$ & $5,15^{\mathrm{A}}$ \\
90 & $5,83^{\mathrm{A}}$ & $5,03^{\mathrm{A}}$ \\
\hline Médias & $6,17^{\mathrm{A}}$ & $5,17^{\mathrm{B}}$ \\
F(épocas) & $1,28 \mathrm{n} . \mathrm{s}$ & $0,66 \mathrm{n} . \mathrm{s}$ \\
\hline
\end{tabular}

n.s= não significativo

As módias seguidas das mesmas letras não diferem entre si, ao nível de $5 \%$ de probabilidade.

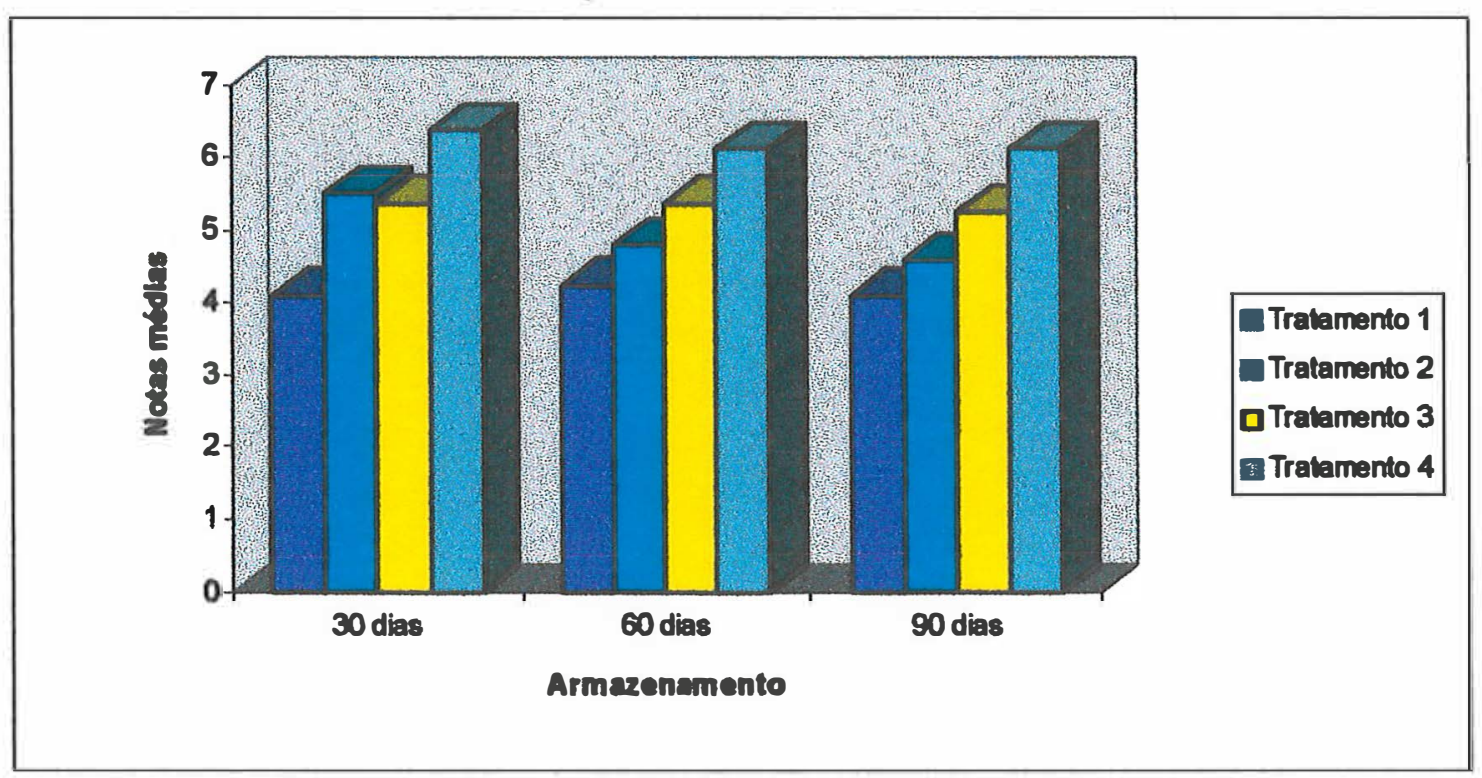

Figura 41. Valores médios obtidos na avaliação sensorial das geléias dietéticas quanto ao sabor durante armazenamento- Variedade Oso Grande.

Em relação à cor observa-se pela Tabela 25 , que para a variedade Guarani nos três meses de armazenamento o tratamento 2 ( polpa de morango + pectina + edulcorantes + fosfato tri-cálcio + sorbato de potássio + cloreto de estanho) diferiu dos demais tratamentos, sendo que este foi considerado o melhor tratamento em relação a este atributo (Figura 42). Para a variedade Oso Grande o tratamento 3 ( polpa de morango + pectina + edulcorantes + fosfato tri-cálcio + ácido cítrico + 
sorbato de potássio + cloreto de estanho) diferiu dos demais tratamentos e foi considerado o melhor tratamento em relação à cor durante os três meses de armazenamento (Figura 43).

Segundo Andreotti et al. (1973), com a adição de íons de alumínio e estanho em geléias de morango há a formação de um forte complexo colorido metal-antocianina que mantem a cor das geléias após o processamento. As geléias com as piores cores foram aquelas em que foi adicionado ácido ascórbico ( tratamento+ 3 para a variedade Guarani e 4 para a Oso Grande). Segundo Freedman \& Francis (1984), a adição de ácido ascórbico em diferentes tipos de geléias acelera o nível de escurecimento e degradação dos pigmentos.

Durante os 90 dias de armazenamento verifica-se pela Tabela 26, que não ocorreram mudanças significativas em relação à cor. Com relação às variedades estudadas, observa-se também que os provadores preferiram as geléias elaboradas com a variedade Guarani.

Tabela 25. Avaliação sensorial da cor das geléias dietéticas de morango das das duas variedades durante armazenamento.

\begin{tabular}{|c|c|c|c|c|c|c|}
\hline \multirow{3}{*}{ Tratamentos } & \multicolumn{2}{|c|}{ MÉDIAS } & \multirow{2}{*}{\multicolumn{2}{|c|}{$\begin{array}{l}\text { ANÁ LISES } \\
\text { 60 DIAS }\end{array}$}} & \\
\hline & \multicolumn{2}{|c|}{30 DIAS } & & & \multicolumn{2}{|c|}{90 DIAS } \\
\hline & Guarani & Oso Grande & Guarani & Oso Grande & Guarani & Oso Grande \\
\hline 1 & $4,75^{B}$ & $4,12^{B}$ & $4,00^{B}$ & $4,25^{B}$ & $4,00^{B}$ & $4,00^{B}$ \\
\hline 2 & $6,87^{\mathrm{A}}$ & $5,12^{\mathrm{B}}$ & $6,50^{A}$ & $4,00^{\mathrm{B}}$ & $6,37^{A}$ & $4,25^{\mathrm{B}}$ \\
\hline 3 & $4,60^{B}$ & $6,80^{A}$ & $4,75^{\mathrm{B}}$ & $6,00^{A}$ & $4,12^{B}$ & $6,12^{A}$ \\
\hline 4 & & $3,37^{\mathrm{B}}$ & & $3,50^{\mathrm{B}}$ & & $3,50^{\mathrm{B}}$ \\
\hline F (rat.) & $27,91^{* *}$ & $24,72^{* *}$ & $24,43^{* *}$ & $26,60^{* *}$ & $28,92^{* *}$ & $24,88 * *$ \\
\hline F (provad.) & $11,79^{*}$ & $12,45^{*}$ & $15,67^{*}$ & $13,78^{*}$ & $10,34 *$ & $12,73 *$ \\
\hline
\end{tabular}

** = significativo a nível de $1 \%$

$*=$ significativo a nível de $5 \%$

As médias seguidas das mesmas letras não diferem entre si, ao nível de $5 \%$ de probabilidade. 
Tabela 26. Comparação entre as geléias dietéticas de morango das duas variedades com relação a cor durante armazenamento.

\begin{tabular}{c|cc}
\multirow{2}{*}{$\begin{array}{c}\text { Épocas de avaliaç̃o } \\
\text { (dias) }\end{array}$} & \multicolumn{2}{c}{ Médias das Análises } \\
\cline { 2 - 3 } & Guarani & Oso Grande \\
\hline 30 & $5,41^{\mathrm{A}}$ & $4,87^{\mathrm{A}}$ \\
60 & $5,08^{\mathrm{A}}$ & $4,43^{\mathrm{A}}$ \\
90 & $5,87^{\mathrm{A}}$ & $4,46^{\mathrm{A}}$ \\
\hline Médias & $5,12^{\mathrm{A}}$ & $4,59^{\mathrm{B}}$ \\
F(épocas) & $1,29 \mathrm{n} . \mathrm{s}$ & $1,29 \mathrm{n} . \mathrm{s}$ \\
\hline
\end{tabular}

n.s $=$ nå significativo

As médias seguidas das mesmas letras nåo diferem entre si, ao nivel de 5\% de probabilidade.

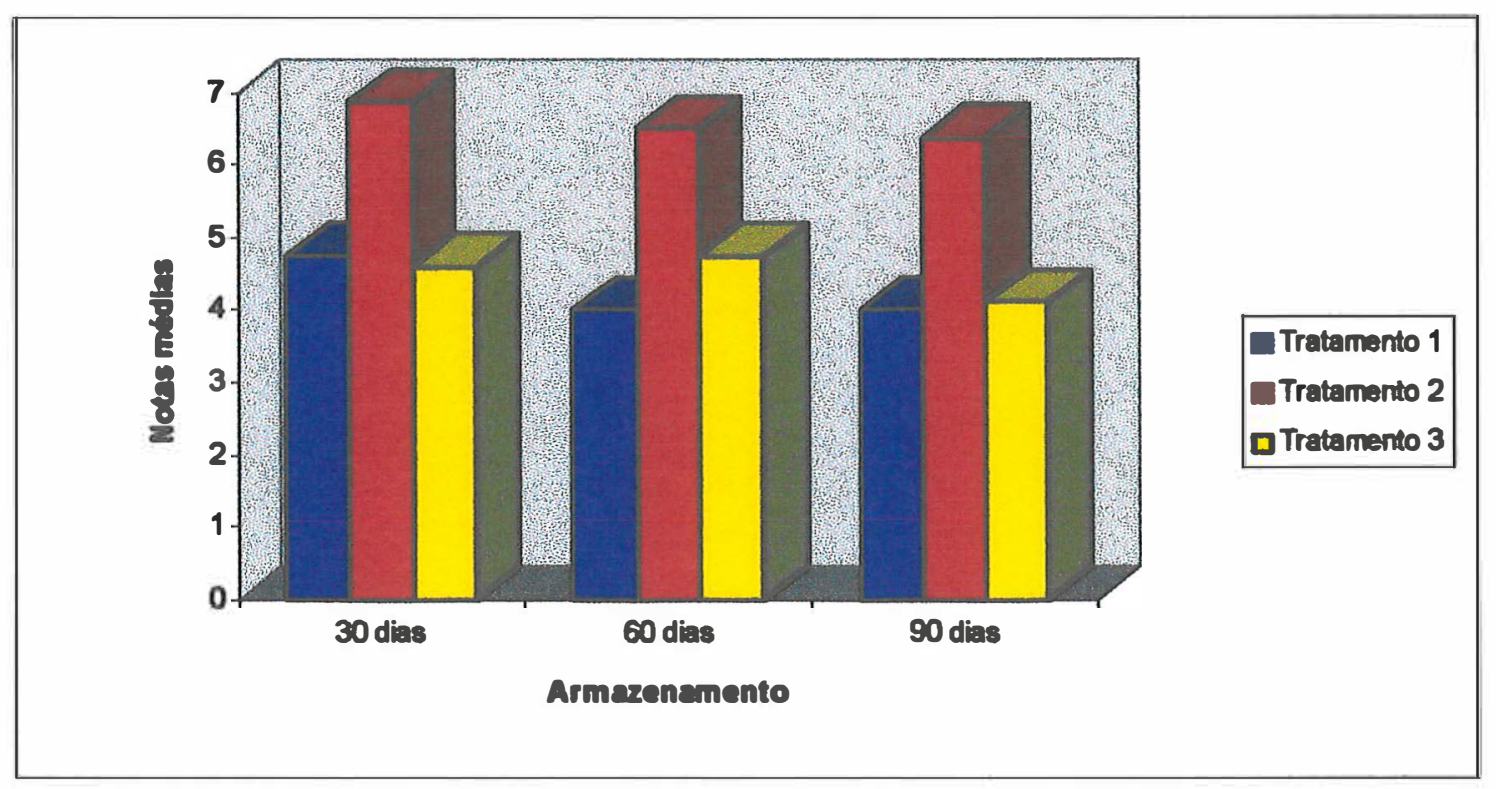

Figura 42. Valores médios obtidos na avaliação sensorial das geléias dietéticas quanto a cor durante armazenamento- Variedade Guarani.

Com relação à textura observa-se pela Tabela 27 que não ocorreram diferenças significaticas entre os tratamentos durante os três meses de armazenamento. De maneira geral, durante as épocas de avaliação sensorial não ocorreram mudanças significativas com relação à textura das geléias dietéticas elaboradas com as variedades Guarani e Oso Grande (Tabela 28). Em relação às variedades estudadas a textura obtida com a variedade Oso Grande foi a 
preferida entre os provadores, obtendo a maior média $(6,52)$, mas estatisticamente não houve diferença significativa entre as médias das texturas das geléias obtidas com as duas variedades estudadas (Tabela 28).

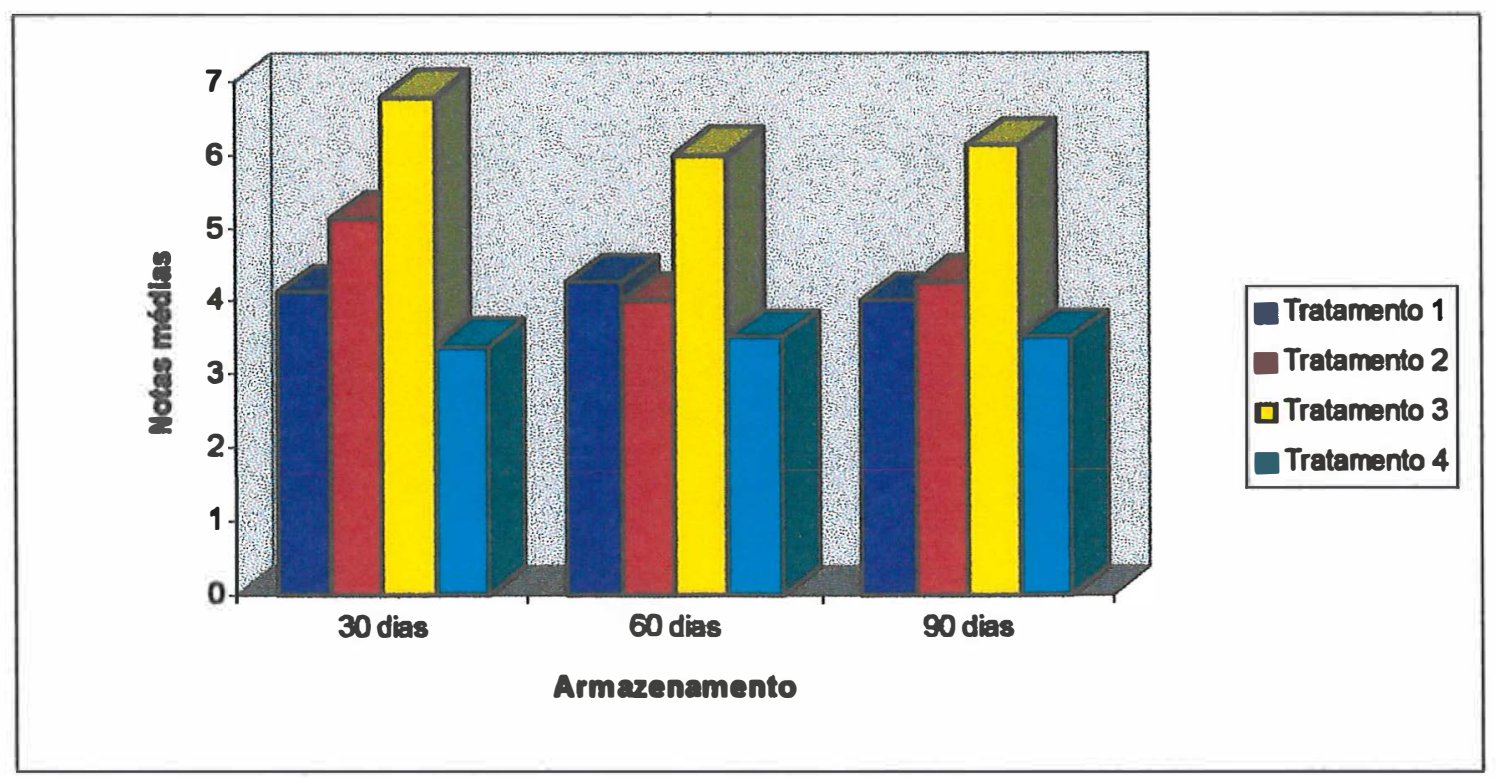

Figura 43. Valores médios obtidos na avaliação sensorial das geléias dietéticas quanto a cor durante armazenamento- Variedade Oso Grande.

Tabela 27. Avaliação sensorial da textura das geléias dietéticas de morango das duas variedades durante anmazenamento.

\begin{tabular}{|c|c|c|c|c|c|c|}
\hline \multirow{3}{*}{ Tratamentos } & \multicolumn{2}{|r|}{ MEDIAS } & \multicolumn{2}{|c|}{ ANA LISES } & \multirow{2}{*}{\multicolumn{2}{|c|}{90 DIAS }} \\
\hline & \multicolumn{2}{|c|}{30 DIAS } & \multicolumn{2}{|c|}{60 DIAS } & & \\
\hline & Guarani & Oso Grande & Guarani & Oso Grande & \multicolumn{2}{|c|}{ Oso Grande } \\
\hline 1 & $6,50^{A}$ & $6,25^{A}$ & $5,37^{\mathrm{A}}$ & $6,25^{A}$ & $5,70^{A}$ & $6,50^{A}$ \\
\hline 2 & $6,75^{A}$ & $6,87^{A}$ & $6,37^{A}$ & $6,12^{A}$ & $6,25^{A}$ & $5,87^{A}$ \\
\hline 3 & $6,87^{A}$ & $6,87^{A}$ & $6,62^{A}$ & $6,50^{A}$ & $6,12^{A}$ & $6,37^{A}$ \\
\hline 4 & & $7,00^{A}$ & & $6,75^{A}$ & & $6,50^{A}$ \\
\hline F (trat.) & 1,89 n.s & 2,34 n.s & 7,86 n.s & $2,66 \mathrm{n} . \mathrm{s}$ & 3,14 n.s & 4,15 n.s \\
\hline F (provad.) & $34,67 *$ & $42,17^{* *}$ & $32,89^{*}$ & $56,22^{*}$ & $35,64 * *$ & 13,24 n.s \\
\hline
\end{tabular}

n.s $=$ não significativo

**= significativo a nível de $1 \% \quad *=$ significativo a nível de $5 \%$

As médias seguidas das mesmas letras não diferem entre si, ao nível de $5 \%$ de probabilidade 
Tabela 28. Comparação entre as geléias dietéticas de morango das duas variedades com relação a textura durante armazenamento.

\begin{tabular}{c|cc}
\hline \multirow{2}{*}{$\begin{array}{c}\text { Épocas de avaliação } \\
\text { (dias) }\end{array}$} & \multicolumn{2}{|c}{ Médias das Análises } \\
\cline { 2 - 3 } & Guarani & Oso Grande \\
\hline 30 & $6,67^{\mathrm{A}}$ & $6,84^{\mathrm{A}}$ \\
60 & $6,29^{\mathrm{A}}$ & $6,40^{\mathrm{A}}$ \\
90 & $6,04^{\mathrm{A}}$ & $6,31^{\mathrm{A}}$ \\
\hline Médias & $6,33^{\mathrm{A}}$ & $6,52^{\mathrm{A}}$ \\
F(épocas) & $1,89 \mathrm{n} . \mathrm{s}$ & $4,18 \mathrm{n} . \mathrm{s}$ \\
\hline
\end{tabular}

n.s = não significativo

As médias seguidas das mesmas letras não diferem entre si, ao nível de $5 \%$ de probabilidade 


\section{CONCLUSÕES}

Dentro das condições experimentais em que foi realizado este trabalho, pode-se chegar às seguintes conclusões:

- Sob o ponto de vista tecnológico, a matéria-prima utilizada apresentou-se de excelente qualidade para o processamento de geléias, quanto às propriedades fisicas (textura, suculência e rendimento) e químicas ( ácido ascórbico, acidez total titulável, $\mathrm{pH}$ e sólidos solúveis (Brix).

- Os teores de ácido ascórbico das geléias comuns e dietéticas mesmo após 180 dias de armazenamento foram considerados bastantes satisfatórios.

- As perdas de ácido ascórbico aumentam com o tempo de armazenamento.

- Com relação ao sabor das geléias comuns, o tratamento 3 (polpa de morango + sacarose + pectina + ácido cítrico + sorbato de potássio + cloreto de estanho) para a variedade Guarani e os 2 (polpa de morango + sacarose + pectina + ácido cítrico), 3 e 4 (polpa de morango+ sacarose + pectina + ácido cítrico + sorbato de potássio + cloreto de estanho + ácido ascórbico) para a 
variedade Oso Grande foram os que obtiveram os melhores resultados em relação a este atributo.

- A adição de ácido ascórbico foi prejudicial a cor das geléias comuns e detéticas, enquanto a presença de cloreto de estanho contribuiu para a estabilidade deste atributo de qualidade.

- As geléias comuns elaboradas com a variedade Oso Grande apresentaram melhor sabor do que as elaboradas com a Guarani.

- As geléias comuns elaboradas com a variedade Guarani apresentaram melhor cor que a Oso Grande.

- As geléias comuns e ditéticas elaboradas com a variedade Oso Grande apresentaram melhor textura que a Guarani.

- Quanto ao sabor das geléias dietéticas o tratamento 3 (polpa de morango + pectina + edulcorantes + fosfato tri-cálcio + sorbato de potássio + cloreto de estanho + ácido ascórbico) para a variedade Guarani e o 4 (polpa de morango + pectina + edulcorantes + fosfato tri-cálcio + ácido cítrico + sorbato de potássio + cloreto de estanho + ácido ascórbico) para a variedade Oso Grande foram os que obtiveram os melhores resultados em relação a este atributo. 
- As geléias dietéticas elaboradas com a variedade Guarani apresentaram melhor sabor e cor do que as elaboradas com a Oso Grande.

- Os resultados obtidos neste trabalho sugerem que a variedade Oso Grande ( com exceção ao atributo cor) é a melhor variedade para obtenção de geléias comuns.

- Os resultados obtidos neste trabalho sugerem que a Guarani é a melhor variedade para obtenção de geléias dietéticas. 


\section{REFERÊNCIAS BIBLIOGRÁFICAS}

ABE, K.; SONOBE, M. Steviosideo in shokuhin koogyo riyoo. New Food Industry, v.19, p.22-67, 1977.

ABERS, J.E.; WROLSTAD, R.E. Causative factors of color deterioration in strawberry preserves during processing and storage. Journal of Food Science, v.44, n.1, p.76-81, 1979.

ADAMS, J.B.; ONGLEY, M.H. The degradation of anthocyanins in canned strawberries. Journal of Food Technology, v.18, n.3, p.305-307, 1973.

ALBREGTS, E.E.; HOWARD, C.M. Elemental composition of fresh strawberry fruit. Journal of the American Society for Horticultural Science, v.103, n.3, p.293-296, 1978.

ALMEIDA, P.G. Edulcorantes a opção diet. Engarrafador Moderno, v.7, n.46, p. 57-63, jul./ago., 1996. 
ALVAREZ, M.; SORDI, L.C.; COUTO, A.C.C. Edulcorantes da stevia: características e aplicações. In: ANGELUCCI, E. Edulcorantes em alimentos, Campinas: ITAL, 1989. p.43-46.

ANDREOTTI, R.; TOMASICCHIO, M.; CASTELVETRI, F. Stabilization the color of anthocyanins in fruit preserves by metal ions. Industria - Conserve, v.28, n.4, p.246-253, 1973.

ANGELUCCI, E. Legislação Brasileira. In: ANGELUCCI, E; FURLANETTO, S.M.S.C. Edulcorantes em alimentos. Seminário. Campinas: ITAL/SBCTA, 1990. p.20-30.

ARAÚJO, J.M.A. Conservadores químicos em alimentos. Boletim da Sociedade Brasileira de Ciência e Tecnogia de Alimentos, v.24, n.3/4, p.35-44, 1990.

ASSOCIATION OF OFFICIAL ANALYTICAL CHEMISTS- Official methods of analysis. 12 ed. Washington, 1975. 1094p.

BAKKER, JK.; BRIDLE, P.; KOOPMAN, A. Strawberry juice color. The effect of some processing variables on the stability of anthocyanins. Journal Science of Food Agriculture, v.60, p.471-476, 1992.

BANZATTO, D.A.; KRONKA, S.N. Experimentação agrícola. 3 ed. Jaboticabal:FUNEP, 1995. 247p. 
BERBARI, S.A.G. Avaliação da qualidade de algumas variedades de morango para o processo de congelação. Piracicaba, 1992. 90p. Dissertação (Mestrado) - Escola Superior de Agricultura "Luiz de Queiroz", Universidade de São Paulo.

BOBBIO, F.O.; BOBBIO, P.A. Introdução a química dos alimentos. 2ed. São Paulo: Varela, 1989. 223p.

BOURNE, M.C. Effect of temperature on firmness of raw fruits and vegetables. Journal of Food Science, v.47, n.2, p.440-444, 1982.

BRASIL. Leis, Decretos, etc. Ministério da Saúde. Comissão Nacional de Normas e Padrões para alimentos. Resolução $n^{\circ}$ 04/88 do Decreto Lei $n$. 55.871/65. In: ASSOCIAÇÃO BRASILEIRA DAS INDUSTRIAS DE ALIMENTOS. Compêndio da Legislação de Alimentos. rev.4. São Paulo: ABIA, 1988. v.1/A, p.3.50.

CAMARGO, L.S. Novas variedades de morangueiro no estado de São Paulo. Piracicaba, 1960. 48p. Tese (Doutorado) - Escola Superior de Agricultura “Luiz de Queiroz", Universidade de São Paulo.

CAMPOS, A.M.; CÂNDIDO, L.M.B. Formulação e avaliação físico-química e reológica de geléias de baixo teor de sólidos solúveis com diferentes tipos de 
adoçantes e edulcorantes. Ciência e Tecnologia de Alimentos, v.15, n.3, p.268-278, 1995.

CARBONELL, E.; COSTELL, E.; DURÁN, L. Rheological indices of fruit content in jams: influence of formulation on time-dependent flow sheared strawberry and peach jams. Journal of Texture Studies, v.22, p.457-471, 1991.

CARDELLO, H.M.A.B.; MORAES, M.A.C.; CARDELLO, L. Ácido ascórbico e escorbato oxidase em manga (Mangifera indica L.) var. Haden processada e congelada. Alimentação e Nutrição, v.5, p.65-75, 1993/94.

CATÁlAGO CITROPECTINA. São Paulo, 5p. 1996.

CHARLAMPOWICZ, Z.; WOZNIAK, W. Potentiometric determination of ascorbic acid. Przemysl - Spozywczy, v.23, n.3, p. 108-111, 1969. Resumo em CAB abstracts on CD-ROM.

CHICHESTER, C.O. The chemistry of plant pigments. New York: Academic Press, 1982. 218p.

CID, C.; BELLO, J.; ATIASARÁN, I. Repercusion de diferentes tipos de tratamientoss de coccion en el contenido en vitamina $\mathrm{C}$ de las verduras. Alimentaria, p.1-21, jan.-fev., 1990. 
CÓDIGO SANITÁRIO. São Paulo:IMESP, 1991. p.196-210.

COSTELL, E.; CARBONELL, E.; DURÁN, L. Chemical composition and rheological behavior of strawberry jams. Acta Alimentaria, v.16, n.4, p. 319-330, 1987.

CRISTENSEN, S.H. Pectins. In: GLISCKMAN, M. Food hydrocoloids. London: CRC Press, 1986. v.3, p.205-230.

DANA, M.N. The strawberry and its environment. In: CHILDERS, N.F. The strawberry cultivars to making . London: CRC Press, 1980. p.33-34.

DAWSON, R.T. Sensory texting guide for panel evaluation of food beverage. Food Technology, v.18, n.8, p.35-31, 1964.

DIAZ-MARQUINA, A.; MATALLA-GONZALEZ, M.C.; ORZAEVILLANUEVA, M.T. Vitamin $\mathrm{C}$ in dietetic products. II Jams. Alimentaria, n.181, p.23-26, 1987.

EMODI, A. Polyols: chemistry and application. In: LINEBACK, D.C.; INGLETT, G.E. Food carbohydrates. Westeport: Avi Publ., 1982. Cap.4, p.37-61.

A ERA diet. Alimentos e Tecnologia, v.7, n.38, p.34-35, 1991. 
ESKIN, N.P.M. Quality and preservation of fruits. Boca Raton: CRC Press, 1991. 205p.

EVANGELISTA, J. Tecnologia de alimentos. Rio de Janeiro:Atheneu, 1992. $652 \mathrm{p}$.

FAO- Activies Related to Sustainable Agricultural Development and Environment. October, 1990. 352p.

FELIPE, G.M. Stevia rebaudiana (Bert.): uma revisão. Ciência e Cultura, v.29, p.1240-1248, 1977.

FERNANDES, MH.C. Vida de prateleira de enlatados de origem vegetal. Boletim do Instituto de Tecnologia de Alimentos, v.19, n.3, p.227-252, jul/set, 1982.

FERREIRA, V.L.P. Teoria da cor. Campinas :ITAL, 1991. p.7-34.

FILGUEIRA, F.A.R. Manual de olericultura: cultura e comercialização. São Paulo: Agrômica Ceres, 1982. 91p.

FISZMAN, S.M. Propriedades funcionales de los hidrocolóides pollisacarídicos. Revista Agroquimica Ciencia y Tecnologia, v.29, n.4, p.415-429, 1989. 
FONSECA, H.; NOGUEIRA, J.N. Processamento e conservação de alimentos de origem vegetal-frutas. In: CAMARGO, R. Tecnologia de produtos agropecuários. Alimentos. São Paulo: Nobel, 1984. cap.7, p.113-124.

FREEDMAN, L.; FRANCIS, F.G. Effect of ascorbic acid on color of jellies. Journal of Food Science, v.49, n.4, p.1212-1213, 1984.

GAVA, A.J. Princípios de tecnologia de alimentos. São Paulo: Nobel, 1984. $284 p$.

GIRARDOT, N.F.; PERYAM, D.R.; SHAPIRO, R. Selection oof sensory testing panels. Food Technology, v.6, n.4, p.140-143, 1953.

GOMES, F.P. Curso de estatística experimental. 5 ed. São Paulo: Nobel, 1973a. 458p.

GROPPO, G.A.; TESSARIOLI NETO, J. A cultura do morangueiro. Campinas: CATI, 1991. 16p.

GROSS, J. Pigments in fruits. New York: Academic Press, 1987. 100p.

HANCOCK, J.F. Ecological genetics of natural strawberry species. Hortscience, v.25, p.869-871, 1990. 
HUDSON, M.A.; LEACH, M.; SHARPLES, V.J.; PICKFORD, E. Home frosen strawberries. I influences of freezing medium, fanning, syrup, temperature, soaking time, storage time and temperature, and rates of frezzing and thawing on sensory assessments. Journal of Food Technology, v.10, n.6, p.681-688, 1975.

INSTITUTO DE ECONOMIA AGRÍCOLA. São Paulo, 1997. (Comunicação pessoal)

ISHIMA, N.; KATAYAMA, O. Sensory evaluation of steviosideo as a sweetener. Resp. Nat. Fool. Resp. Inst., v.31, p.80-85, 1976.

JACKIX, M.H. Industrialização de frutas em calda e cristalizadas, geléias e doces em massa. São Paulo: Secretaria da Industria e Comércio, Ciência e Tecnologia,1982. p.107-238.

KAMNEVA, Z.P.; LISAKOVA, N.P. The manufaturing of a dietetic jam using sorbitol. Acta- Alimentaria- Polonica, v.12, n.3/4, p.161-175, 1973.

KIMURA, K.; IDA, M.; YOSIDA, Y.; OHKI, K.; FUKUMOTO, T.; SAKUI, N. Comparasion of keeping quality between pressure-processed jam and heatprocessed jam: changes in flavor components, hue, and nutrients during storage. Bioscince Biotechinal Biochemical, v.58, n.8, p.1386-1391, 1994. 
KOZUP, J.; SISTRUNK, W.A.; MORRIS, J.R. Chemical stabilization of color in machine-harvest strawberries. Arkansas- Farm-Research, v.29, n.4, p.5, 1980.

LEME JÚNIOR, J. Contribuição ao estudo da geleificação de frutas e do equilibrio do gel péctico. Piracicaba, 1968. 97p. Dissertação (Mestrado) Escola Superior de Agricultura "Luiz de Queiroz", Universidade de São Paulo.

LEME JÚNIOR, J. Geléias de frutas. Industria Alimentar, v.1, n.3, p.28-33, 1976.

LEME JÚNIOR, J.; MALAVOLTA, E. Determinação fotométrica de ácido ascórbico. Anais da Escola Superior de Agricultura "Luiz de Queiroz", v.7, p.115-129, 1950.

MARKAKIS, P. Anthocyanins as food colors. New York: Academic Press, 1982. 280p.

MARQUINA, D.; GONZÁLEZ, M.C.; VILLANEVA, M.C. Vitamina C en productos dietéticos II. Mermeladas. Alimentaria, p.23-27, abr., 1987.

MARTIN, S.L. Selection and training of sensory judges. Food Technology, v.27, n.11, p.22-26, 1973. 
MAY, C.D.; STANSBY, G. Factors affecting pectin gelation. In: PHILLIPS, G.O.; WEDLOCK, D.J.; WILLIANS, P.A. Gums and stabilisers for food industry. London: Elservier Applied Science, 1986, p.515-524.

MAZZA, G.; MINIATI, M.Sc. Anthocyanins in fruits, vegetables and grains. London: Boca Raton, 1990. 113p.

MITCHELL, J.R.; BLANSHARD, M.V. Rheological proprieties of gels. Journal of Food Texture Studie, v.7, p.341-351, 1976.

MIYOSH, H. Steviosideo no Tsukemono e riyoo. Shokunin kaihatsu, v.12, p.31-36, 1977.

MOORE, W.J. Físico-Química. São Paulo: Edgard, 1976. Cap. 10, p.385-391.

MORRIS, J.R.; SISTRUNK, W.A. The strawberry. In: ESKIN, N.P.M. Quality and preservation of fruit. Boston: Boca Raton, 1991. Cap. 9. p.181-203.

MORRIS, J.R.; SISTRUNK, W.A. The strawberry. London: CRC Press, 1991. 212p.

MURADIAN, L.B.; PENTEADO, M.V.C. Edulcorantes em alimentos. Boletim da Sociedade Brasileira de Ciência e Tecnologia de Alimentos, v.24, n.1/2, p.1-11, 1990. 
NABORS, L.O.; GELARDI, R.C. Alternative sweeteners. New York: Marcel Dekker, 1986. 461p.

NELSON, L.O.; BARRITT, B.H.; WOLFORD, E.R.; TORRE, L.C. Processing evaluation of strawberry cultivars growm in Western Washington. Pullman College of Agriculture Center, p.5, 1976.

OAKENFULL, D.G.; SCOTT, A.G. Gelation of high methoxil pectins. Food Technology in Australia, v.37, n.4, p. 48-52, 1985.

PADOVANI, M.I. Morango: o delicado e saboroso fruto da integração dos povos. São Paulo: Icone, 1991. 68p.

PASCHOALINO, J.E. Congelamento de frutas e hortaliças. In: TEIXEIRA NETO, R.O.; coord. Curso de alimentos congelados, Campinas: ITAL, 1979. p.2-27.

PASSOS, F.A. Caracterização de clones nacionais e introduzidos de morangueiro (Fragaria $x$ ananassa Duch), visando o uso emediato na horticultura e o melhoramento genético. Piracicaba, 1982. 116p Dissertação (Mestrado) - Escola Superior de Agricultura "Luiz de Queiroz", Universidade de São Paulo. 
PASSOS, F.A.; TESSARIOLI NETO. Avaliação da capacidade de remoção do fruto sem cálice em diversos clones de morangueiro pertencentes a diversos genêros e espécies. Revista de Olericultura, v.1, p.64-65, 1979.

PAVANELLO, F.J. O uso de aditivos em alimentos. Alimentos e Bebidas, v.7, p.22-24, 1990.

PEDERSEN, J.K. Carrageenan, pectin and xanthan/locust bean gels: trends in their use. Food Chemistry, v.6, p.77-78, 1980.

RAMOS, M.; GONZÁLEZ, J.; REUVERS, Th.; RUIZ, E. Contenido de vitaminas A, C y E em diferentes tipos de alimentos del mercado spanõl. Alimentaria, p.50-51, dez., 1989.

RANDI, A.M.; FELIPE, G.M. Detecção de esteviosideo e substâncias giberelínicas em aquênios de Stévia rebaudiana e efeitos de esteviosideo em germinação. Ciência e Cultura, v.33, n.4, p.440-410, 1980.

RIBEIRO, Z.M.A.; GARCIA, N.C.P.; SPERRY, S. Morango. Brasilia: EMBRAPA/DID, 1981. 91p. (Resumos Informativos)

RICHARDS, N.S.P. Avaliação da qualidade das variedades Chandler e Reiko para a obtenção de morango em calda. Piracicaba, 1996. p.90. Dissertação (Mestrado) - Escola Superior de Agricultura "Luiz de Queiroz", Universidade de São Paulo. 
RODRIGUES, C. Diet e light. Alimentos e Tecnologia, v.9, n.58, p.55-58, 1995.

SAKAGUCHI, M.; KAN, T. As pesquisas japonesas com stevia rebaudiana (Bert.) Bertoni e o esteviosideo. Ciência e Cultura, v.34, n.2, p.236-248, 1982.

SÁNCHEZ, M.T. Food Texture: concept and measurement. Alimentaria, p.2933, maio, 1996.

SIGUEMOTO, A.T. Manual técnico do I seminário sobre hidrocolóides em alimentos. Campinas :ITAL, , 1993. 90p.

SIMÃO, A.M. Uso de aditivos para alimentos sob aspectos toxicológicos. São Paulo: Nobel, 1985. 80p.

SISTRUNK, W.A.; CASH, J.N. The effect of certain chemicals on the color and pollysaccharides of strawberry puree. Food Technology, v.24, n. 4, p.473$477,1970$.

SKREDE, G.; WROLSTAD, P.I.; ENERSEN,G. Color stability of strawberry and blackcurrant syrups, Journal of Food Science, v.57, n.1, p.172-177, 1993. 
SKREDE, G. Changes in sucrose, fructose and glucose content in frozen strawberries with thawing. Journal of Food Science, v.48, n.4, p.10941096, 1992.

SKREDE, G. Quality characterisation of strawberries for industrial jam production. Journal Science of Food Agriculture, v.33, p.48-54, 1982.

SKREDE, G. Strawberry varieties for industrial production. Journal Science of Food Agriculture, v.31, p.670-676, 1980.

SONDHEIMER, E.; KERTESZ, Z.I. The anthocyanin of strawberries. Journal of American Chemistry Society, v.70, p.3476, 1948.

SOLER, M.P. Industria de geléias. Campinas: ITAL, 1991. 80p. (Manual Técnico)

SPAYD, S.E.; MORRIS, J.R. Influence of immature fruits of strawberry jam quality and storage stability. Journal of Food Science, v.46, n.2, p.414-418, 1981.

SPOZYWCZY, L.V. Storage conditions for jam. Izvestiga-VysshikhZavedenii-Pischevaya-Teknologiya, v.6, p.3-31, 1992. Resumo em FESTA abstrats on CD-ROM. 
SWEETING the foods of 1980s. Food Processing, p.34-35, july, 1979.

TEIXEIRA, C.G. Ciência e tecnologia e o problema alimentar. O Estado de São Paulo, 14 de janeiro. 1993. p.2. (Caderno de Empresas).

TESSARIOLI NETO, J. Influência de cobertura permeável e impermeável sobre o solo e planta na produção de morangueiro (Fragaria x ananassa Duch). Piracicaba, 1993. 112p. Dissertação (Mestrado) - Escola Superior de Agricultura "Luiz de Queiroz", Universidade de São Paulo.

VIBERG, U.; EKSTROM, G.; FREDLUND, K.; OSTE, R.E; SJONOLM, I. A study of some important vitamins and antioxidants in a blackcurrant jam with low sugar content and without additives. Internacional Journal of Food Science and Nutrition, v.48, p.57-66, 1997.

VOTH, V.; BRINGHURST, R.S. Culture and physiological manipulation of California strawberries. Hortscience, v.25, n.8, p.889-892, 1990. 